\title{
Facies Belts and Communities of the Arctic Vesterisbanken Seamount (Central Greenland Sea)
}

\author{
Rüdiger Henrich, Kiel, Martin Hartmann, Kiel, \\ Joachim Reitner, Berlin, Priska Schäfer, Kiel, André Freiwald, Kiel, \\ Stefan Steinmetz, Bremerhaven, Peter Dietrich, Freiberg, \\ and Jörn Thiede, Kiel
}

\section{KEYWORDS: GREENLAND SEA - SPONGE BRYOZOAN MOUND - SPICULITE DEVELOPMENT - MICROBIAL BINDING - ARCTIC FORAMOL FACIES - BENTHIC COMMUNITIES - HOLOCENE}

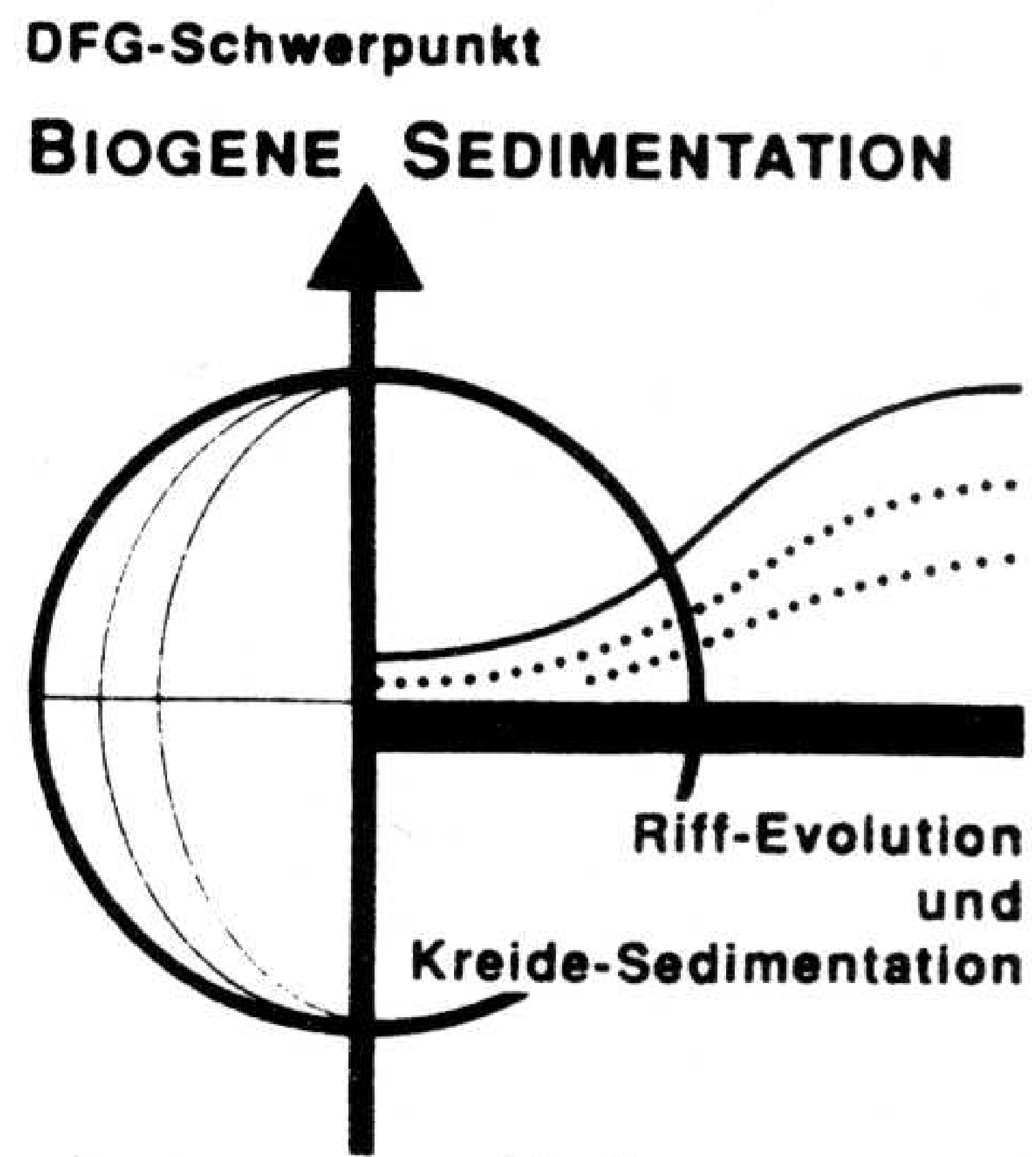

\section{CONTENT}

Summary

1 Introduction

$1.1 \quad$ Regional setting and previous studies

1.2 Oceanography

2 Methods

$2.1 \quad$ Hydrosweep survey

2.2 Surveys with Ocean Floor Observation System

2.3 Detection of hydrothermalism

2.4 Sampling of sediments and organisms

2.5 Methods of fixing biological material

3 Results

3.1 Bathymetry of the Vesterisbanken Seamount

3.1.1 General aspects

3.1.2 Crest morphology

3.1.3 Slope morphology

3.2. Facies belts

3.2.1 The Crest facies

3.2.2 The Shallow slope facies

3.2.3 The Deep slope facies

3.3 Indications for hydrothermal activity

4 Discussion

4.1 Sediment dynamics

4.2 Formation of spiculites

4.3 Bryozoan ecology

4.3.1 Species composition

4.3.2 Depth zonation, growth forms and adaptation to seasonal food supply

4.3 The vagile epibenthos

4.4 Arctic mixed siliceous and carbonaceous deposits: the modern end members of the Foramol facies?

5 Conclusions

References

\section{SUMMARY}

The Arctic Vesterisbanken Seamount, situated far offshore in the central Greenland Sea, provides a unique facility for studying modern cold water siliceous carbonate deposits. A nearly year round sea ice cover, which retreats on average only during two months, and a rather constant temperature and salinity structure of the water column characterize the Arctic conditions of the area.

Despite predominantly oligotrophic conditions with a pronounced food supply from the pelagic realm only during the ice-free season, the seamount is covered extensively by extended sponge-bryozoan constructions. Three distinct facies belts reveal a pronounced depth zonation which depends on variations in downslope food transfer and which is specifically effective due to the development of a TAYLOR current regime over the seamount:

i) the crest facies from the summit at $-133 \mathrm{~m}$ to $-260 \mathrm{~m}$, ii) the shallow slope facies from $-260 \mathrm{~m}$ to $-400 \mathrm{~m}$, iii) the deep slope facies from $-400 \mathrm{~m}$ down to the abyssal plain at about $3.000 \mathrm{~m}$. Different biogenic structures and communities are found within these facies belts, including widely extended biogenic mats, sponge bryozoan-serpulid buildups with mounds, hedges, spurs and flatcake-like structures, bryozoan thickets and sponge-crinoid mounds. Depth zonation, internal structure and controlling parameters in the formation of these biogenic structures are discussed in the context of their significance as a modern end member of the Foramol facies and their implication for the fossil record. In addition, the younger volcanic and hydrothermal history of the seamount is presented with special reference to its bearing on Holocene biogenic colonization patterns.

\section{INTRODUCTION}

Benthic communities on shelves and in near coastal areas are determined by a large variety of natural and anthropogenic constraints that exaggerate strong environmental stress on the organisms and thus effect specific survival strategies. Due to 


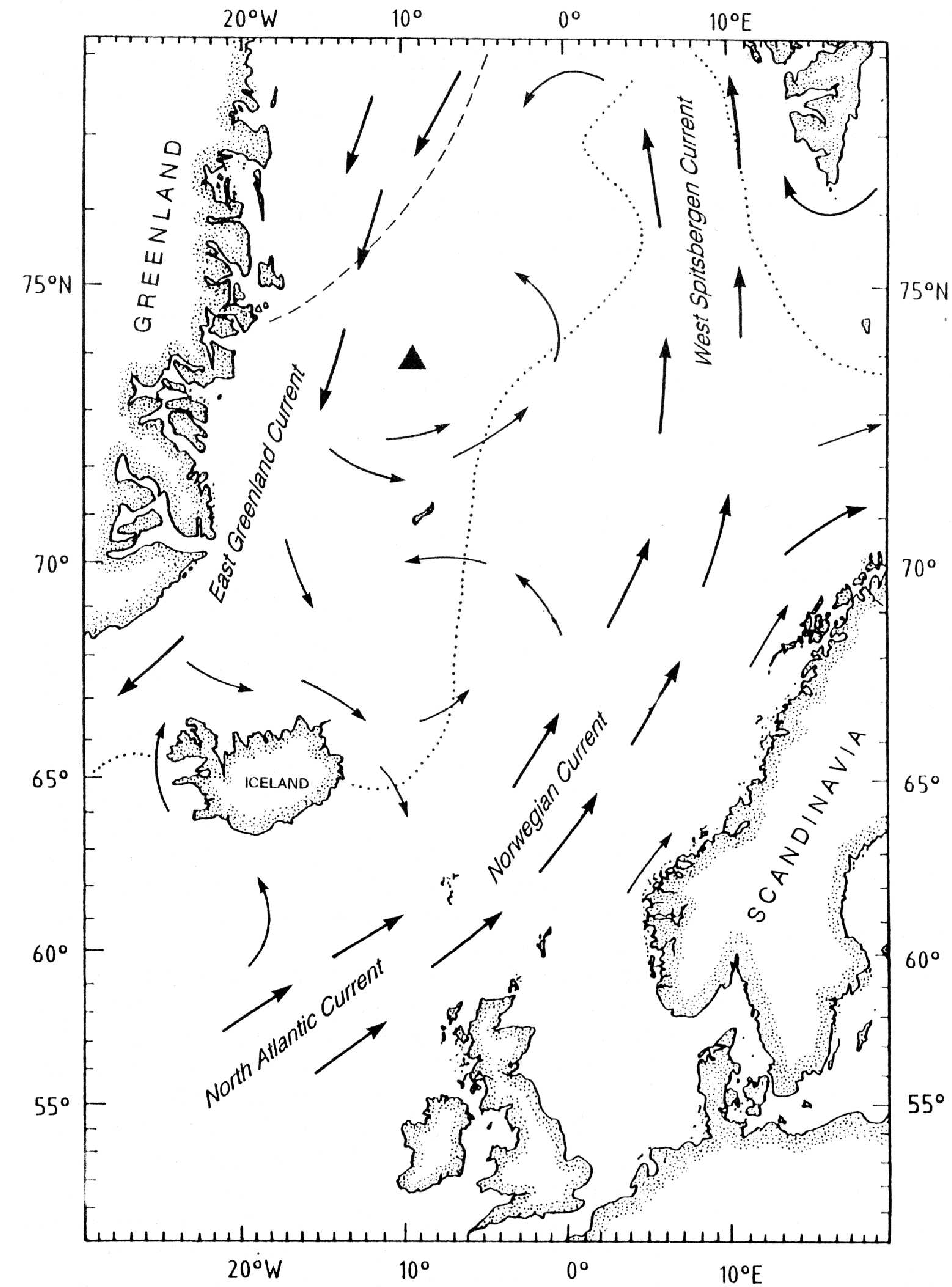

Fig. 1. Location of the Vesterisbanken Seamount (triangle) in the central Greenland Sea. Circulation of recent surface waters in the Norwegian-Greenland Sea and in the northeastern North Atlantic are indicated by black arrows. Extension of sea ice is indicated for

a) mild summersituation (dashed line), and

b) severe winter situation (dotted line).

the complexity of these environmental constraints it is often hard to deduce principle factors that control the internal structure of benthic communities. In contrast, offshore open ocean conditions are more strictly confined, thus providing a better chance for investigating controlling parameters of benthic ecosystems. As a consequence, open ocean seamounts are unique natural laboratories for conducting studies on benthic ecosystems. In particular they provide facilities for:

-- the study of variations in settling strategies and structures of benthic ecosystems in response to open ocean water mass characteristics and pelagic food supply.

-- the investigation of colonization patterns of benthic communities on various substrates, e.g. soft bottom, firm ground and volcanic hard ground.
-- the evaluation of the principle parameters that control depth-related zonation of organisms.

-- the deciphering of sea level changes in response to glacial/ interglacial climatic shifts from compositional changes in the topmost Holocene benthic communities and sediments.

We report observations from an Arctic seamount, the Vesterisbanken, central Greenland Sea, made during the Arctic (ARK) VII/1 expedition with RV PolarsterN in June/July 1990 (Fig. 1). This volcano has a variety of pecularities. It is the only known Arctic seamount with Holocene, and possibly still ongoing, volcanic activity. Due to its position close to the polar front it is characterized by a strong seasonality in surface water regimes. On average, the area is covered nearly year round with a dense ice pack, which retreats westward for two months, most commonly 


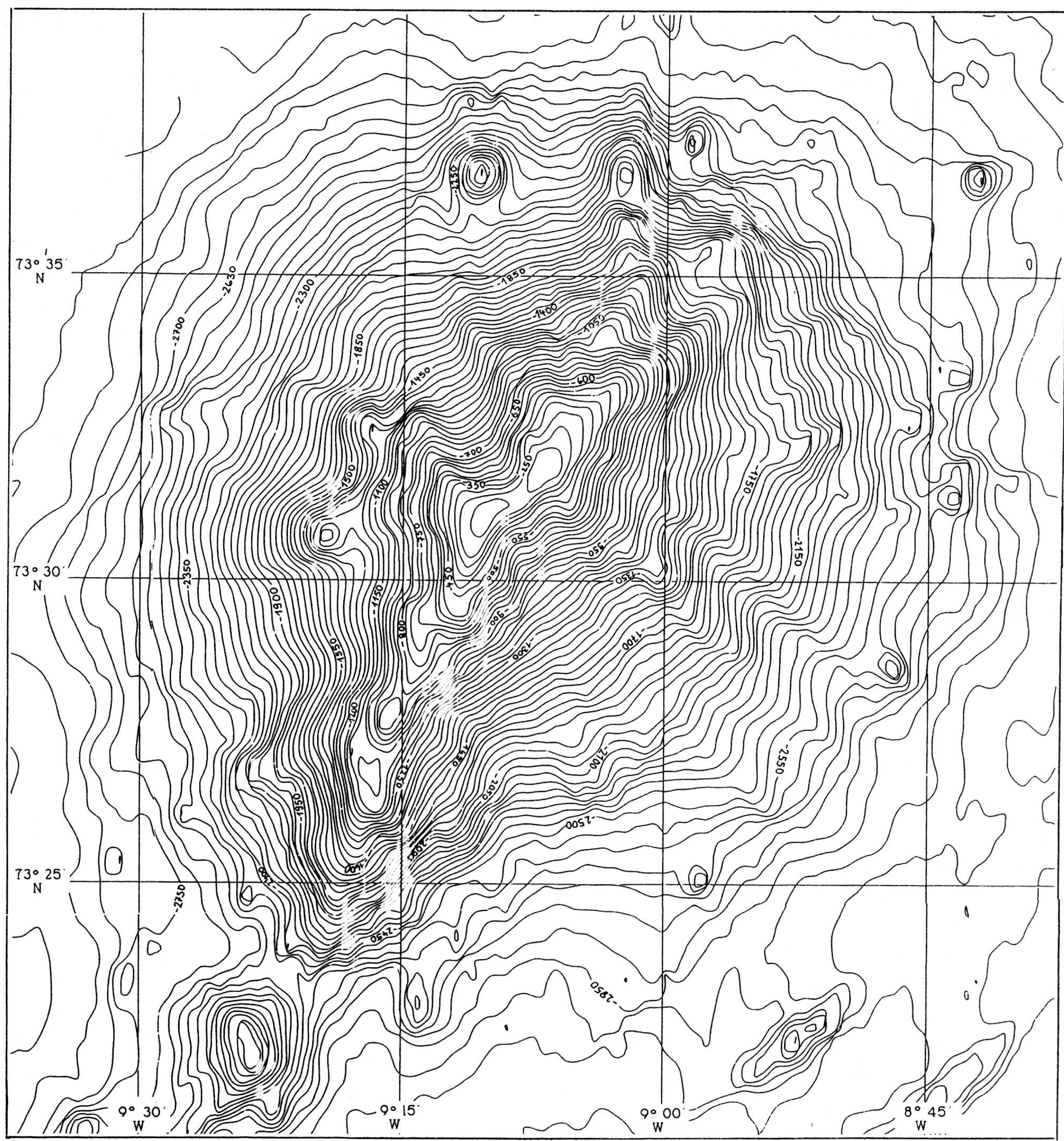

Fig. 2. Bathymetric map of the Vesterisbanken Seamount based on hydrosweep transects during ARK VII/1 expedition with RV PolARSTERN. Data-processing facilities are provided by the Alfred-Wegener-Institute, Bremerhaven.

during August and September. Because of these strong environmental constraints, ecological studies on the Vesterisbanken benthic communities may provide us with a much better knowledge of Arctic benthic communities with exceptionally high population densities, survival strategies and benthic organism adaptations to episodic or continous food supply from planktic primary producers.

\subsection{Regional setting and previous studies}

Vesterisbanken Seamount is an intraplate volcano in the south-western area of the Greenland Basin at $73^{\circ} 30^{\prime} \mathrm{N}$ and $9^{\circ} 10^{\prime} \mathrm{W}$, approximately $280 \mathrm{~km}$ north of Jan Mayen and $300 \mathrm{~km}$ east of the East Greenland Continental Margin (Fig. 2). It is positioned on magnetic anomaly no. 19, which corresponds to an crust age of $44 \mathrm{Ma}$ (ELDHOLM \& THIEDE 1980). Vesterisbanken was first shown in a bathymetric map published by EGGVIN (1963). A first combined bathymetric, geological and geophysical survey was carried out during ARK II Expedition of RV POLARSTERN in 1984 (AUGSTEIN et al. 1984). Results from seven sea beam tracks were integrated in a more detailed bathymetric map of the seamount (HEMPEL et al. 1991). This map shows a slightly SW-NE-elongated seamount rising up from $-3.100 \mathrm{~m}$. The summit reaches - 
$133 \mathrm{~m}$. Based on these initial results, the bathymetry of the Vesterisbanken was investigated in much more detail with a complete regional coverage of overlapping hydrosweep tracks during the ARK VII/1 expedition (THIEDE \& HEMPEL 1991). Additionally, during the ARK V/3a expedition of RV POLARSTERN in late spring of 1988 , a short sampling program indicated the presence of a rigid bryozoan and siliceous sponge mat.

Faunal assemblages of Arctic and Subarctic shelves have been analyzed in various previous studies. Most typical of all these occurrences is a prevalence of molluscs, siliceous sponges, bryozoans, echinoderms and serpulids (PIEPENBURG 1988 and further references therein). The monographs used for the identification of invertebrates from the Vesterisbanken are listed below (Tab. 1).
Tab. 1. Monographs used for identification of invertebrates from the Vesterisbanken Seamount.

\section{Porifera}

Armauer Hansen (1885)

BREITFUSS (1898)

BRÖNSTEDT (1914)

BURTON $(1934,1959)$

FRISTEDT (1885)

HENTSCHEL (1916)

Koltun $(1959,1964,1966$, $1967,1970)$

LAMBE $(1896,1900)$

LUNDBECK $(1902,1905,1909)$

MARENZELLER (1886)

MEREJKOWSKY (1878)

NoRDGAARD (1918)

SCHULZE $(1900,1903)$

SteEnstrup \& TENDAL (1982)

TENDAL $(1970,1979)$

VOSMAER (1885)

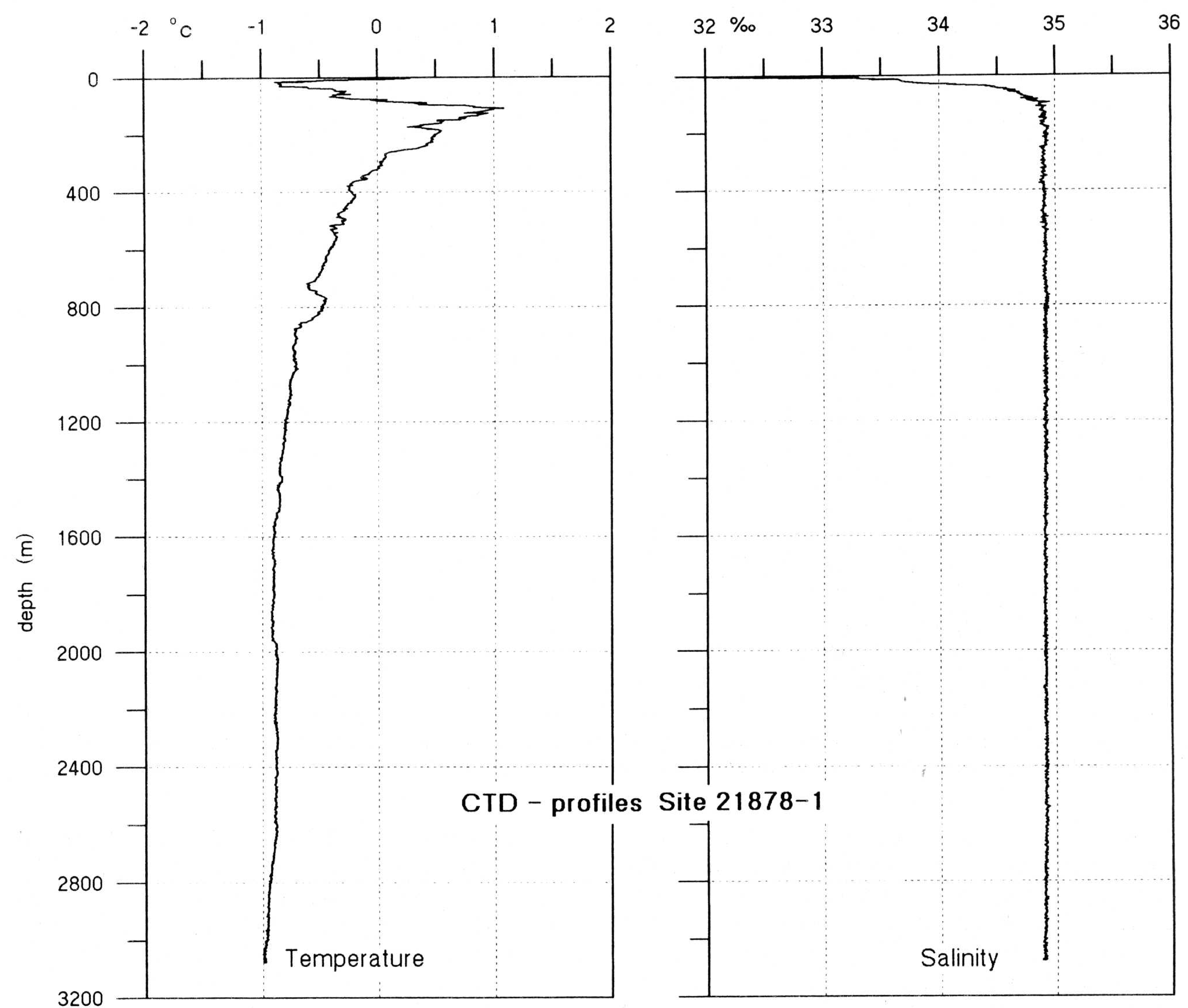

Fig. 3. Temperature and salinity gradients through the water column close to the Vesterisbanken Seamount in June 1990 taken from CTD-site 21878-1.Typical summer configuration with a low salinity tongue of $20 \mathrm{~m}$ thickness at the surface, floating on a $100 \mathrm{~m}$ thick water lens of colder water with gradually increasing salinity and temperature (temperature maximum $+1.1^{\circ} \mathrm{C}$ at $-110 \mathrm{~m}$ ). Intermediate and deep water masses record a nearly constant temperature and salinity $\left(34.88\right.$ to $\left.34.84 \mathrm{ppt} ; 0^{\circ} \mathrm{C} \pm 1^{\circ} \mathrm{C}\right)$. 


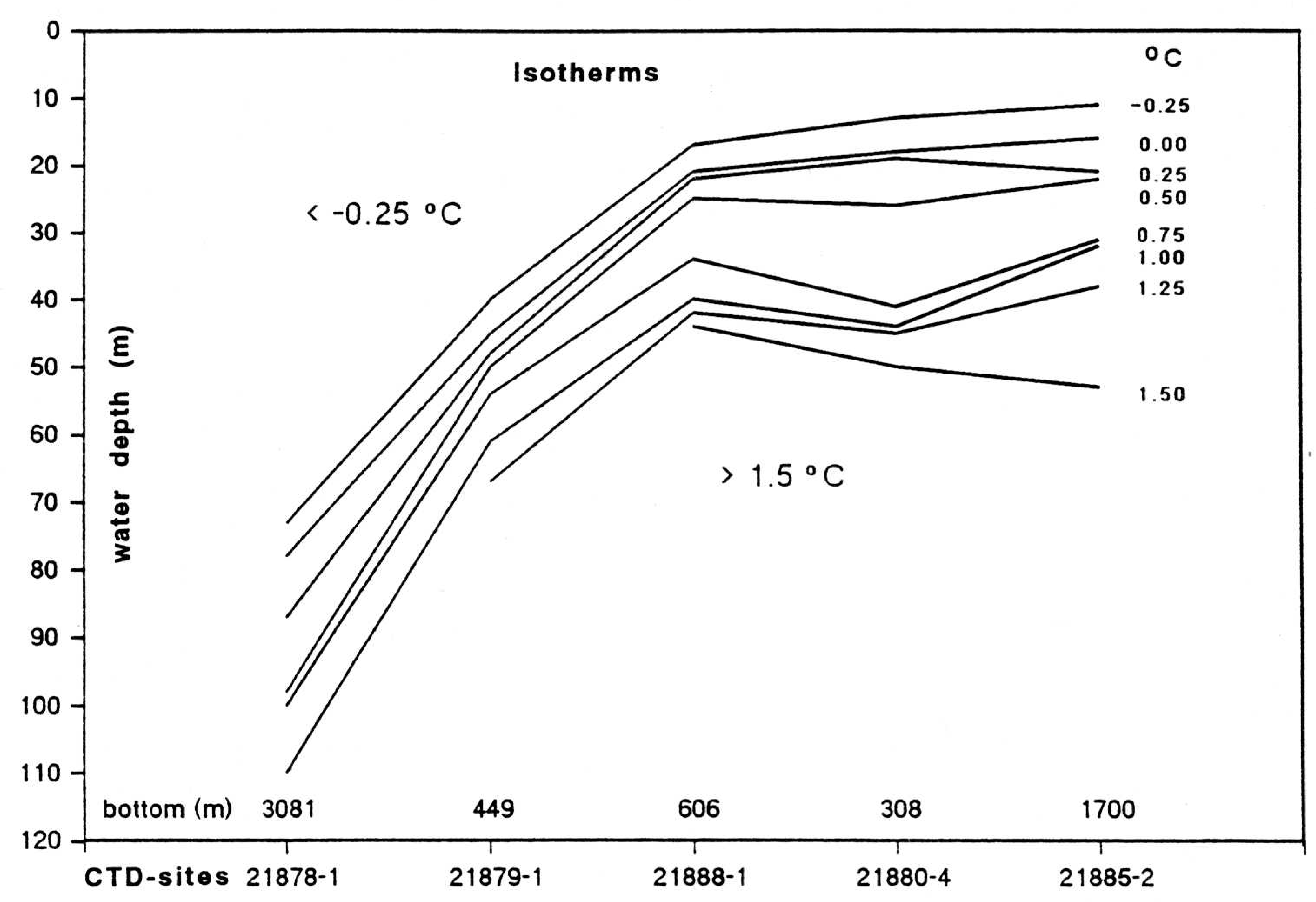

Fig. 4. Uplifted isotherms over the Vesterisbanken Seamount give evidence for a TAYLOR current regime. The data were compiled from 5 CTD-stations following the crest line of the seamount (compare with Fig. 5).

\subsection{Oceanography}

The oceanography of the Norwegian-Greenland Sea depicts steep E-W gradients in surface water regimes. On the eastern side, the Norwegian Current, the northern prolongation of the Gulf Stream, carries warm saline Atlantic water to the high north Arctic region, while on the western side the Greenland Current (EGC) transports cold, less saline Arctic water to the south. The EGC is covered by a seasonally variable sea ice pack (JOHANNESSEN 1986, SwIFT 1986). A wide area in the centre of the Norwegian-Greenland Sea is occupied by a mixed water mass, the Arctic surface water, with slightly higher temperatures and salinities than the EGC.

When warm and salty North Atlantic waters become exposed to the cold autumn and winter atmosphere in the Greenland and Iceland Seas, they are cooled by complex interactive processes. This cooled water becomes dense and ultimately convects and sinks to the bottom. The newly formed deep water is well oxygenated and ventilated because it has just been in contact with the atmosphere. It flows southward across the sills of the Greenland-Scotland Ridge and forms North Atlantic Deep Water.

The cold EGC moving southward along the Greenland continental margin is responsible for sea ice coverage at the Vesterisbanken site for most time of the year. The positions of pack ice boundaries are displayed in Fig. 1.

A temperature/salinity profile taken with a CTD-probe at site 21878-1 (about 15 nautical miles to the south of the summit of Vesterisbanken Seamount) is shown in Fig. 3. It illustrates the principal structure of the water column in the Vesterisbanken area to $-3000 \mathrm{~m}$. The profile shows a tongue of low salinity water only $20 \mathrm{~m}$ thick with downwards increasing salinity and decreasing temperature $\left(+0.3^{\circ} \mathrm{C}\right.$ to $0.9^{\circ} \mathrm{C}$ ). This configuration reflects a typical summer situation with an influence of freshwater from melting sea ice fields. This low salinity surface water lens floats on a $100 \mathrm{~m}$ thick layer of colder water that gradually increases in salinity and temperature with depth to a temperature maximum of $+1.1^{\circ} \mathrm{C}$ at $-110 \mathrm{~m}$. Below this layer the temperature decreases continuously with depth while a nearly constant salinity ( 34.88 and $34.94 \mathrm{ppt}$ ) is found throughout the entire lower profile section. The minimum temperature $\left(-1.0^{\circ} \mathrm{C}\right)$ is observed near the bottom at $-3071 \mathrm{~m}$.

In almost stable stratified water masses a seamount obstacle creates distinct current regimes that are known as TAYLOR columns (TAYLOR 1923). This current regime is expressed by an anticyclonal downwelling vortex. Although we have no direct observations from current measurements, there is other independent evidence for a TAYLOR column above the Vesterisbanken Seamount:

-- The water temperature structure along a transect of CTDsites across the seamount depicts uplifted isotherms over the summit (Fig. 4).

--Sea ice charts reveal the ice edge with a typical bump in the area of the Vesterisbanken during those periods of the year, when areas north and south are already ice free (VINJE 1985).

Average ice conditions over the top of the seamount are much heavier than in surrounding areas, possibly indicating a trapping of ice over the seamount.

\section{METHODS}

\subsection{Hydrosweep survey}

The bathymetric mapping of the Vesterisbanken Seamount was performed during ARK VII Expedition in 1990 (THIEDE \& HEMPEL 1991) with a hydrosweep multibeam deep-sea echosounding system recording the topography along a profile strip of $\pm 45^{\circ}$ width. In order to get complete coverage, overlapping profiles were run, starting at the top along a spiral-like course around the seamount edifice. The raw profiles were processed on board to exclude offsets along the transect. 


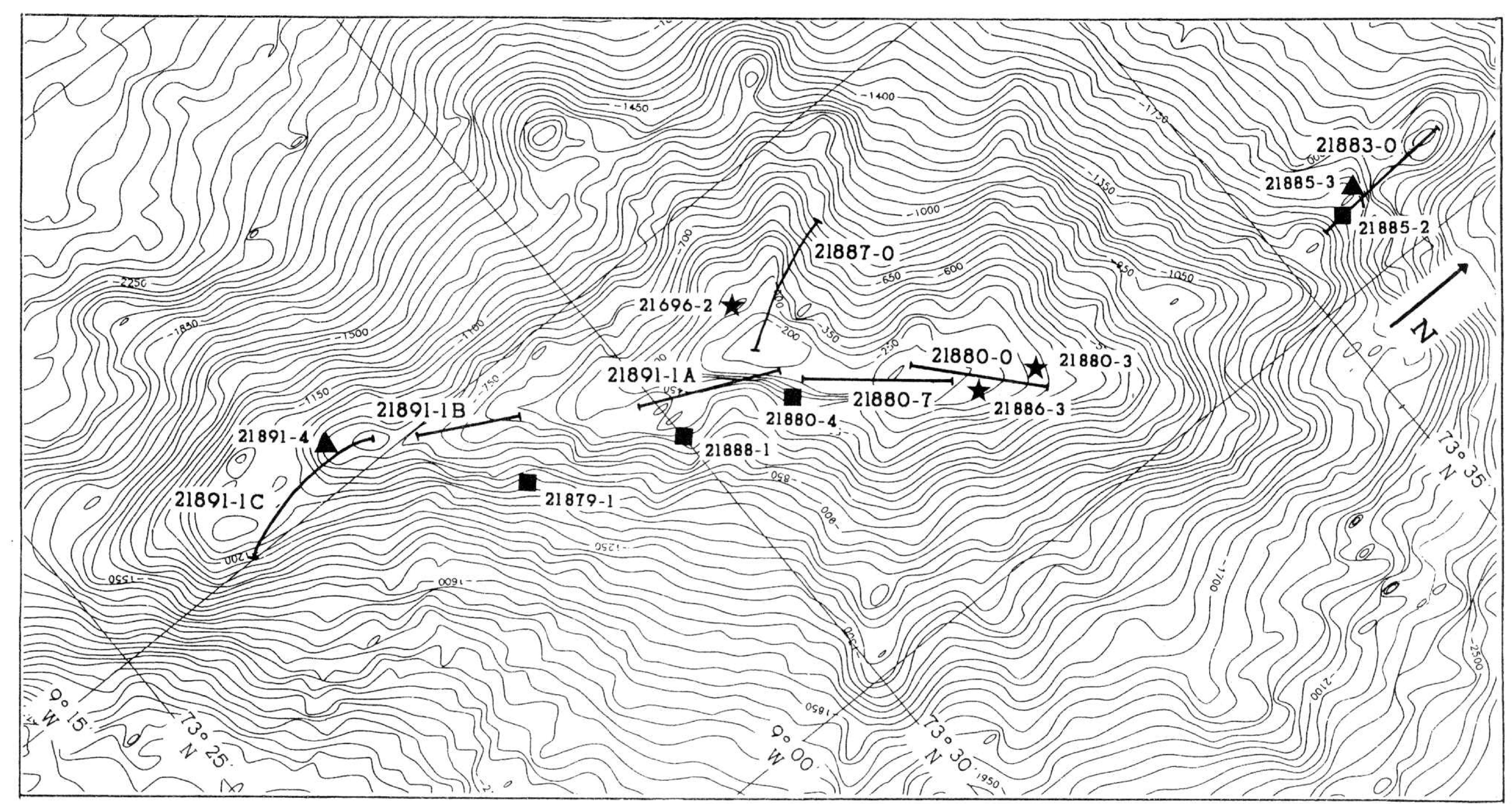

Fig. 5. Enlarged section of the crest line. The sites of OFOS tracks (thick line), TV-grabs (triangle), box corer (asterisk), and CTD-probes (square) are included.

\subsection{Surveys with Ocean Floor Observing System}

A first visual mapping of bottom features and ecology at Vesterisbanken Seamount was carried out with an Ocean Floor Observing System (OFOS). The OFOS was equipped with a black and white video camera, 4 floodlights, and a photo camera combined with flash. Film lengths for up to 800 slides ( 24 x $36 \mathrm{~mm}$ size) could be loaded. KodakEktachrome 200 ASA colour slide film material was used. More than 1000 photos were taken along $20 \mathrm{~km}$ total length of 7 OFOS-profiles on Vesterisbanken Seamount. An independent control of the real depth position was possible by hydrostatic pressure readings from a CTD-probe (Conductivity - Temperature - Depth) unit attached to the OFOS-frame. The mean ship speed during video observation was around 0.7 nautical miles/h (equivalent to 0.3 and $0.4 \mathrm{~m} /$ sec).

Based on the hydrosweep map, four OFOS surveys were made along the seamount summit to investigate topography-related sea floor characteristics and volcanic structures (Fig. 5). Two OFOS-profiles were run along the crest line over the summit of the seamount. Both profiles were started at the northeastern peak almost at the same point. Profile $21880-0$ is facing downslope towards NE, while profile $21880-7$ is facing downslope towards SW. Additional tracks were performed in the upper section of the NW-flank (profile 21887-0) and downslope the SW-crest (21891-1 A) starting from the southwestern summit peak. ThreeOFOS surveys (21883-0, 21891-1B, 21891-1C) cover flank areas deeper than $-400 \mathrm{~m}$ (Fig. 5).

\subsection{Detection of hydrothermalism}

Physical parameters of water masses around a seamount may differ significantly from the surrounding areas. One of the scientific targets was the discovery of active hydrothermalisms, indicated by anomalies in the water. Hydrothermal activity is detectable by:

- direct methods (visual observation)

- indirect methods, a) recording of temperature anomalies and b) recording of geochemical anomalies in the water column.

In order to study the principle water mass structure of the Vesterisbanken and to localize potential hydrothermal vents, CTD-profiles were run and water samples were taken at 5 sites from the top region, flanks, and adjacent deep sea (Tab. 2 , Fig. 5) with a rosette water sampler in combination with a CTD-device. A continous record of salinity, temperature, and hydrostatic pressure was received from each water column profile. A maximum of nine water samples was able to be taken at each hydrocast site. They were positioned mainly in the deeper sections of the respective water column.

The sites (Fig. 5) for hydrocast stations were chosen according to morphologic features and as near as possible to the OFOS-profile tracks. The water samples were prepared on board for determination of manganese and methane in the shore-based lab. Manganese was measured by graphitefurnace atomic absorption after separation from salt content and enrichment by a factor of 40 (HaRTMANN et al. 1989). For

Tab. 2. Positions of CTD-probe and hydrocast sites. Compare with Fig. 5.

\begin{tabular}{|crcc|}
\hline Station & $\begin{array}{c}\text { Bottom depth } \\
\text { m }\end{array}$ & $\begin{array}{c}\text { Latitude } \\
\mathbf{N}\end{array}$ & $\begin{array}{c}\text { Longitude } \\
\mathbf{W}\end{array}$ \\
\hline $21878-1$ & 3081 & $73^{\circ} 15.00$ & $9^{\circ} 00.00$ \\
$21879-1$ & 449 & $73^{\circ} 28.68$ & $9^{\circ} 11.68$ \\
$21880-4$ & 308 & $73^{\circ} 31.10$ & $9^{\circ} 08.60$ \\
$21885-2$ & 1685 & $73^{\circ} 35.70$ & $9^{\circ} 02.26$ \\
$21888-1$ & 606 & $73^{\circ} 30.00$ & $9^{\circ} 09.93$ \\
\hline
\end{tabular}




\begin{tabular}{|c|c|c|c|c|c|}
\hline Station & $\begin{array}{l}\text { Latitude } \\
\qquad \mathbf{N}\end{array}$ & $\begin{array}{l}\text { Longitude } \\
\underset{W}{ }\end{array}$ & $\begin{array}{l}\text { bottom } \\
\text { depth }(m)\end{array}$ & $\begin{array}{l}\text { sampling } \\
\text { device }\end{array}$ & $\begin{array}{c}\text { recovery } \\
\mathrm{cm} / \mathrm{kg}\end{array}$ \\
\hline 21696-2 & $73^{\circ} 31.00$ & $09^{\circ} 11.1$ & 235 & giant box corer & 20 \\
\hline $21878-2$ & $73^{\circ} 15.10$ & $09^{\circ} 00.94$ & 3.038 & giant box corer & 48 \\
\hline 21878-3 & $73^{\circ} 15.33$ & $09^{\circ} 00.74$ & 3.048 & gravity corer & 510 \\
\hline $21880-3$ & $73^{\circ} 32.80$ & $09^{\circ} 04.77$ & 333 & giant box corer & 27 \\
\hline $21882-1$ & $73^{\circ} 35.52$ & $08^{\circ} 23.80$ & 3.169 & giant box corer & 17 \\
\hline $21882-2$ & $73^{\circ} 35.96$ & $08^{\circ} 19.29$ & 3.175 & gravity corer & 755 \\
\hline $21886-3$ & $73^{\circ} 32.29$ & $09^{\circ} 05.22$ & 260 & giant box corer & 18 \\
\hline 21892-1 & $73^{\circ} 44.05$ & $09^{\circ} 37.52$ & 3.125 & giant box corer & 28 \\
\hline $21892-3$ & $73^{\circ} 44.06$ & $09^{\circ} 41.17$ & 3.002 & gravity corer & 450 \\
\hline $21885-3$ & $73^{\circ} 35.86$ & $09^{\circ} 02.48$ & 1.619 & TV-grab & $150 \mathrm{~kg}$ \\
\hline 21891-4 & $73^{\circ} 27.43$ & $09^{\circ} 16.34$ & 727 & TV-grab & $100 \mathrm{~kg}$ \\
\hline
\end{tabular}

Tab. 3. Listed sites and sampling device of the bottom sampling program on the seamount during ARK V/3a and ARK VII/1 expedition. analysing the methane concentrations, the gas-content was extracted from 11 seawater on board using an ultrasonic degassing method (Schmiтt et al. 1991). The extracted gas samples were transferred to gas-tight glas vessels and measured after the expedition by M. SchмiтT (Fa. "Geochemische Analysen", Lehrte) with a GC-system.

\subsection{Sampling of sediments and organisms}

Sediments and organisms of soft-bottom and semistabilized firm ground were sampled with giant box corers (occasionally also grabs) and chain-dredges, which were mainly used to collect rock samples from hard bottoms (e.g. pillow lavas). Some samples were made by using a large TVgrab. The adjacent deep-sea plain was sampled with a long gravity corer (Tab. 3).

The determination of the benthos is based on underwater photographs, collected material from the seamount and from comparison with additional samples from the Jan Mayen Ridge and the Greenland Fracture Zone.

\subsection{Methods of fixing biological material}

All collected organisms were registrated and immediately fixed. From large sponges $(>10 \mathrm{~cm})$ small pieces were cut off and fixed first with $4 \%$ glutaraldehyde solution in seawater buffered with sodium cacodylate and after 20 hours washed and preserved in increasing alcohol concentrations (30-50$70 \%$ ). Some samples were post fixed with $2 \%$ osmium tetroxide for SEM and TEM studies. A large number of specimens were fixed in $10 \%$ formaldehyde solution in seawater for two days and than preserved in $70 \%$ alcohol. Very big specimens were primarily fixed in $95 \%$ alcohol. The sponges are housed in the Institut für Paläontologie der Freien Universität Berlin, the remaining organisms are housed in the Geomar Institute in Kiel.

\section{RESULTS}

\subsection{Bathymetry of the Vesterisbanken Seamount}

\subsubsection{General aspects}

The bathymetry of the Vesterisbanken area shows an isolated seamount clearly elongated in NE - SW direction (Fig. 2,5). This prefered direction is underlined by the crest structure of the main edifice. About 15 to 20 side cones, elevating up to $500 \mathrm{~m}$ above their surroundings, cover the deeper flanks (e.g. at the $-2.500 \mathrm{~m}$ to $-3.000 \mathrm{~m}$ level) at various places. The distribution pattern of side cones underlines the general strike of the seamount, specifically in the southwestern region. The NE - SW striking morphologic features correspond to the lineation of magnetic anomalies in this area, suggesting a causal relationship between plate configuration and the pathways for ascending magmas.

The main edifice of the Vesterisbanken (mean diameter about $28 \mathrm{~km}$ at the $-2.800 \mathrm{~m}$ level) ascends from the 3.100 $\mathrm{m}$-deep basin floor up to $-133 \mathrm{~m}$. No crater-like structures were found neither in the top area nor in the side cones. Slope steepness exceeding $24^{\circ}$ is present over large areas of the seamount. Along the OFOS-profiles, vertical escarpments exceeding $10 \mathrm{~m}$ were found in several places.

The volcanic material recovered from two dredge hauls during ARK II expedition consisted of basanite and trachyandesite (HöRMANN \& RAASE 1991). During ARK VII/ 1 expedition 4 dredge hauls and 5 TV-grabs were run on the Vesterisbanken Seamount. The rock material recovered represents fresh to slightly altered volcanics with a high proportion of phenocrysts in fine-grained matrix with rare glass. The volcanics can be grouped into a basanite-tephrite series and an alkalibasalte-trachybasalte-mugearite series following the classification of LE BAs etal. (1986). The suite of rocks is typical of intraplate lavas, which are characterized by a high enrichment of incompatible elements (HAASE et al. in prep.).

\subsubsection{Crest morphology}

The NE - SW elongated summit shows two morphologic highs with the topmost point at the southwestern head -133 $\mathrm{m}$ (Fig. 5). They are separated by a 55-m-deep saddle. The summit reveals a relatively smooth morphology along the crest line, while steep inclined slopes occur perpendicular to the crest line. The rather smooth relief of the seamount top could have resulted from intensive tidal abrasion during maximum glaciation (e.g. isotope stage 2, FAIRBANKs 1989) when sea level was lowered by $-130 \mathrm{~m}$, exposing the seamount proper in the intertidal zone. If this is correct, no major volcanic eruptions could have affected the top region of the Vesterisbanken later on during the Holocene. A general feature in all crestline OFOS tracks is the gently undulating morphology to the $-300 \mathrm{~m}$ level.

\subsubsection{Slope morphology}

The steepest inclinations occur on the SE as well as on the NW flanks between -300 and $-2.000 \mathrm{~m}$. Nearly vertical 
escarpments exceeding $10 \mathrm{~m}$ were found at several locations. These escarpments consist of sharp-edged block lava or sheetflows; in some cases pillows may be seen. Except for these short escarpment sections, however, the hardrock basement is covered by volcanoclastic sediment (grey to black ash to $\mathrm{cm}$-sized lapilli material) often mixed or alternating with fine-grained pelagic sediments.

A thin sediment cover is present along most sections of steep slope sections. Weak undulation and mini-escarpments of the basalt floor can often be traced under the faint sediment cover. Uncovered black basalt surfaces occur at several sections of the steep profiles, but only over short distances. Most of the outcropping basalts look relatively fresh. However, grey-olive weathering crusts frequently outcrop along profile $21887-0$.

\subsection{Facies belts}

A pronounced faunal zonation exists at the present-day in the carbonate- and silica-producing organisms. The zonation is expressed by distinct benthic communities, growth forms, and population densities that are clearly alined along the seamount flanks:

1. The Crest facies, ranging from $-133 \mathrm{~m}$ to around $-260 \mathrm{~m}$ which are comprised of extensive biogenic mats and mounds constructed by sponges, bryozoans, serpulids, and hydrozoans and occasionally semi-stabilized sandy mud areas.

$\because \because \because \equiv \equiv$ Firm ground
$\because \because \because$ Volcanoclastic deposits
$\vdots \therefore \because \cdots$ Carbonate sand

P Cyclopecten

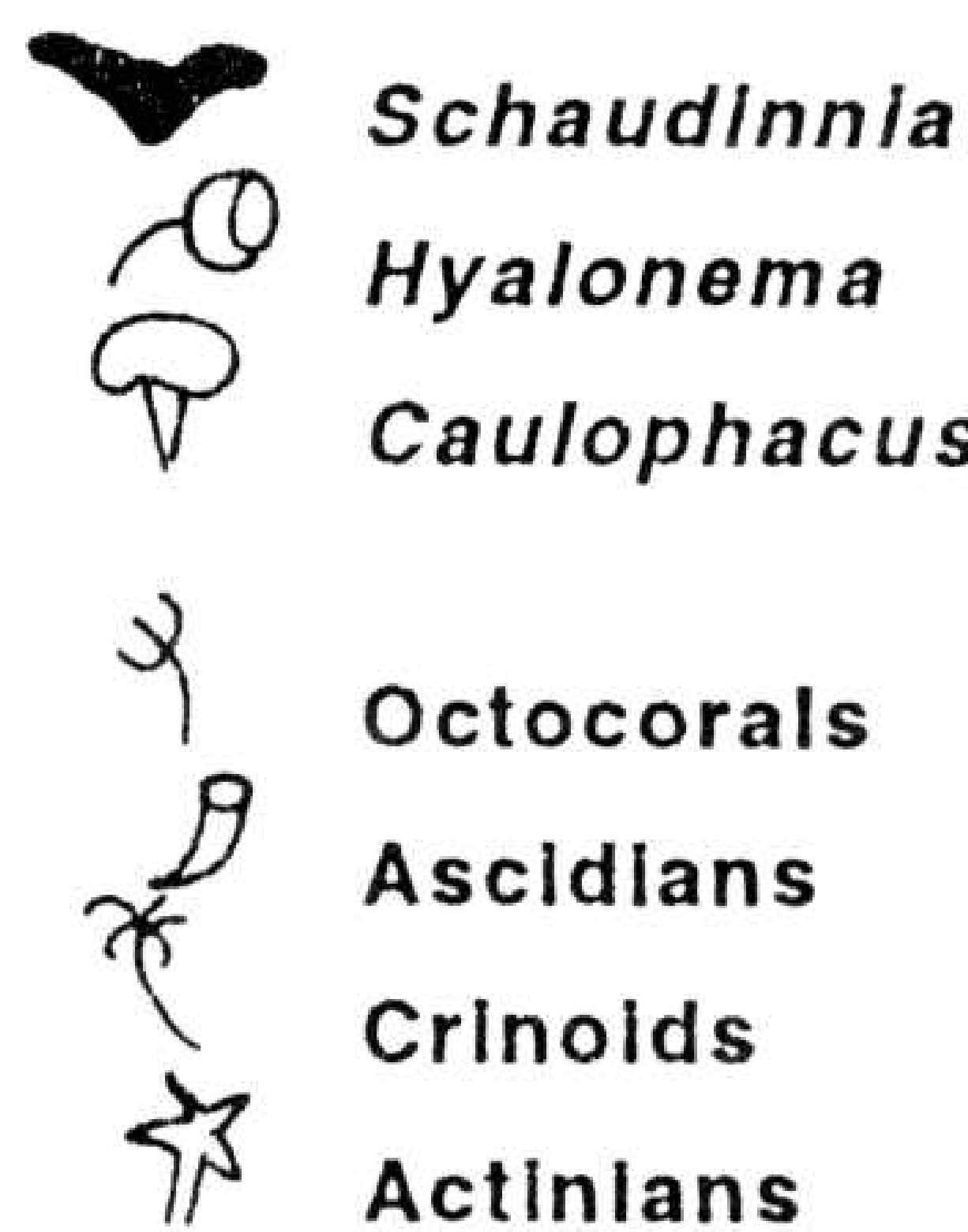

2. The Shallow slope facies, ranging from $-260 \mathrm{~m}$ to approximately $-400 \mathrm{~m}$ is occupied by pectinid bivalves, echinoderms, and epibenthic polychaetes existing on a semistabilized sandy mud. Small sponge-bryozoan mounds are present on morphological highs.

3. The Deep slope facies, ranging from $-400 \mathrm{~m}$ to $-3.000 \mathrm{~m}$ is characterized by soft-, firm-, and volcanic hard grounds with different sponge and crinoid communities.

The adjacent Abyssal plain facies is characterized by softbottom communities (benthic foraminifera, sponges) and a large admixture from planktic organisms.

\subsubsection{The Crest facies}

The top (-133 $m$ to $-260 m)$ of the Vesterisbanken Seamount is almost entirely covered by biogenic material. Over wide areas a dense biogenic mat composed of a close meshwork of large, mostly long-shafted sponge spicules and branched bryozoan fragments forms an almost continous sheet on the sea floor (Figs. 6-8). Dark, fine-grained, microberich sediment is trapped within this network. Light-coloured sandy muds with abundant planktic and benthic foraminifers locally cover the biogenic mat and fill small depressions on the sea floor. At the surface of the biogenic mat and on the sediment-covered areas, a close arrangement of chimney and/or crater-like structures is visible on most photographs. These paired openings are related to filter-feeding endobenthic ascidians.

The stable spicule meshwork of the biogenic mat is an ideal substrate for fixosessile benthic organisms. Because of heavy ice conditions only a single in-situ sample is available from the crest facies of the Vesterisbanken Seamount.

At a ridge north of the western part of the Jan Mayen Fracture Zone a similar facies was sampled at -509 m (Box core GIK 21877). This spiculite mat exhibits a number of unique features most of which

NE

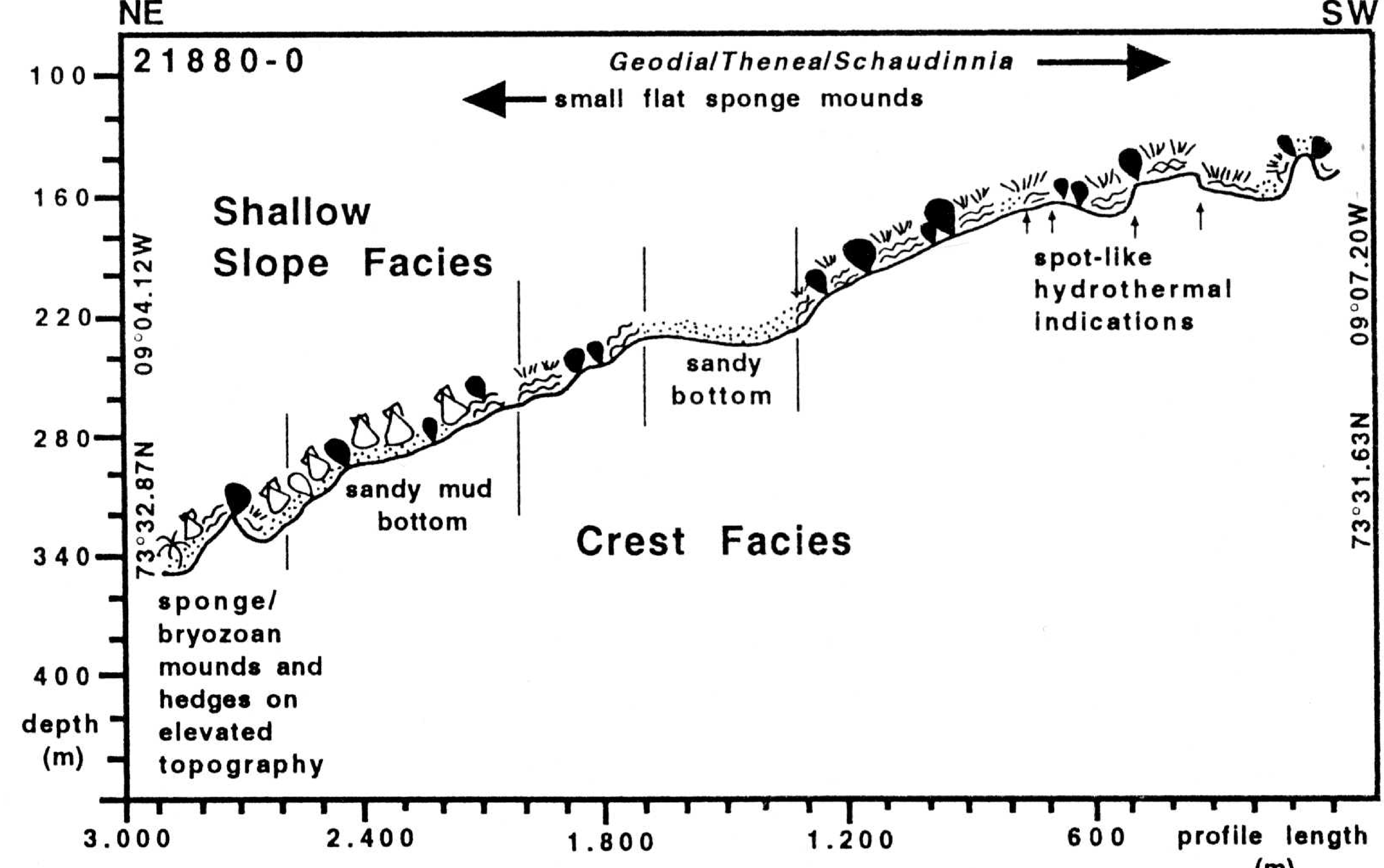

SW

Fig. 6. Bathymetry and facies distribution along OFOS-track 21880-0, northern crest section. 
Fig. 7. Bathymetry and

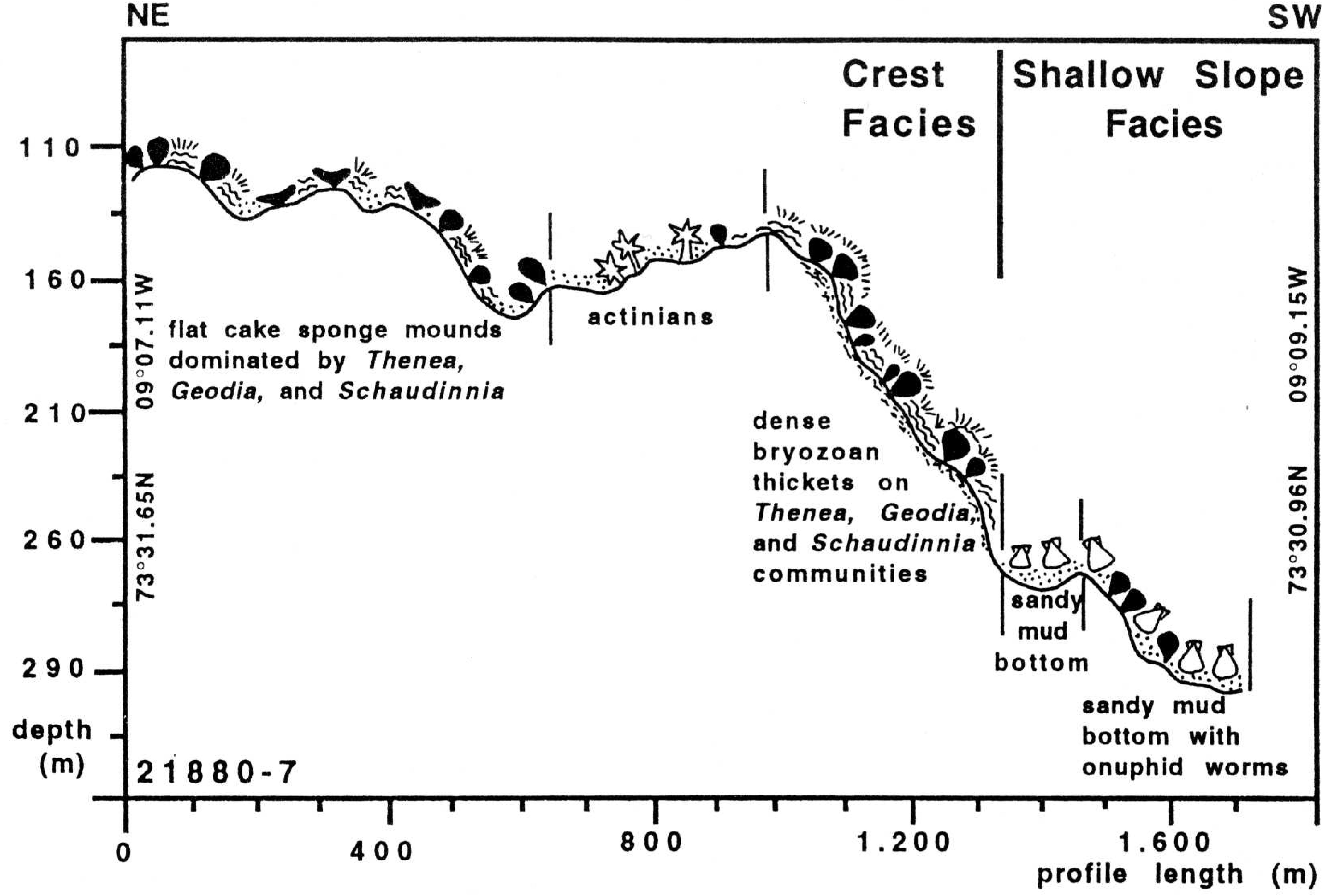
facies distribution along OFOS-track 21880-7, southwestern crest section. For legend see Fig. 6.

resemble many of the pecularities of the biogenic mat from the Vesterisbanken Seamount (PI. 23/1-2). The spiculite from the ridge top contains only small quantities of incorporated sediment. We suppose that sea water continously percolates through the spiculite pore space. The spicules are often completely covered by microbes (P1. 23/3-4). These microbes are capable of binding sediment particles within the spiculite meshwork. In addition, the spiculite mat has numerous small, several $\mathrm{cm}$-sized cavities which are inhabited by a specific cryptic fauna with small sponges, bryozoans and benthic foraminifers (PI. 23/3-6). Another important observation is that sponge larvae settle on spicules, preferentially in the interior parts of the mat (PI. 23/5). As these sponges grow, they push up the spiculite mat. Because of the protection of the spiculite meshwork and the specific taphonomic conditions inside the mat, the sponges may be preserved almost in-situ after death. In summary, the pecularities of the spiculite mat provide us with an excellent example of how autochthonous spiculites can form in-situ near the sediment surface.

The only box core (GIK 21696-2) from the crest facies was taken during the ARK V/3a expedition of RV PoLARSTERN in 1988. The box core was recovered from $-235 \mathrm{~m}$ at $73^{\circ} 31^{\prime} \mathrm{N}$ and $09^{\circ} 11.1^{\prime} \mathrm{W}$ (Fig. 9), a position near the lower boundary of the crest facies. The vertical profile reveals three depositional units: the surface layer with a $10 \mathrm{~cm}$ thick

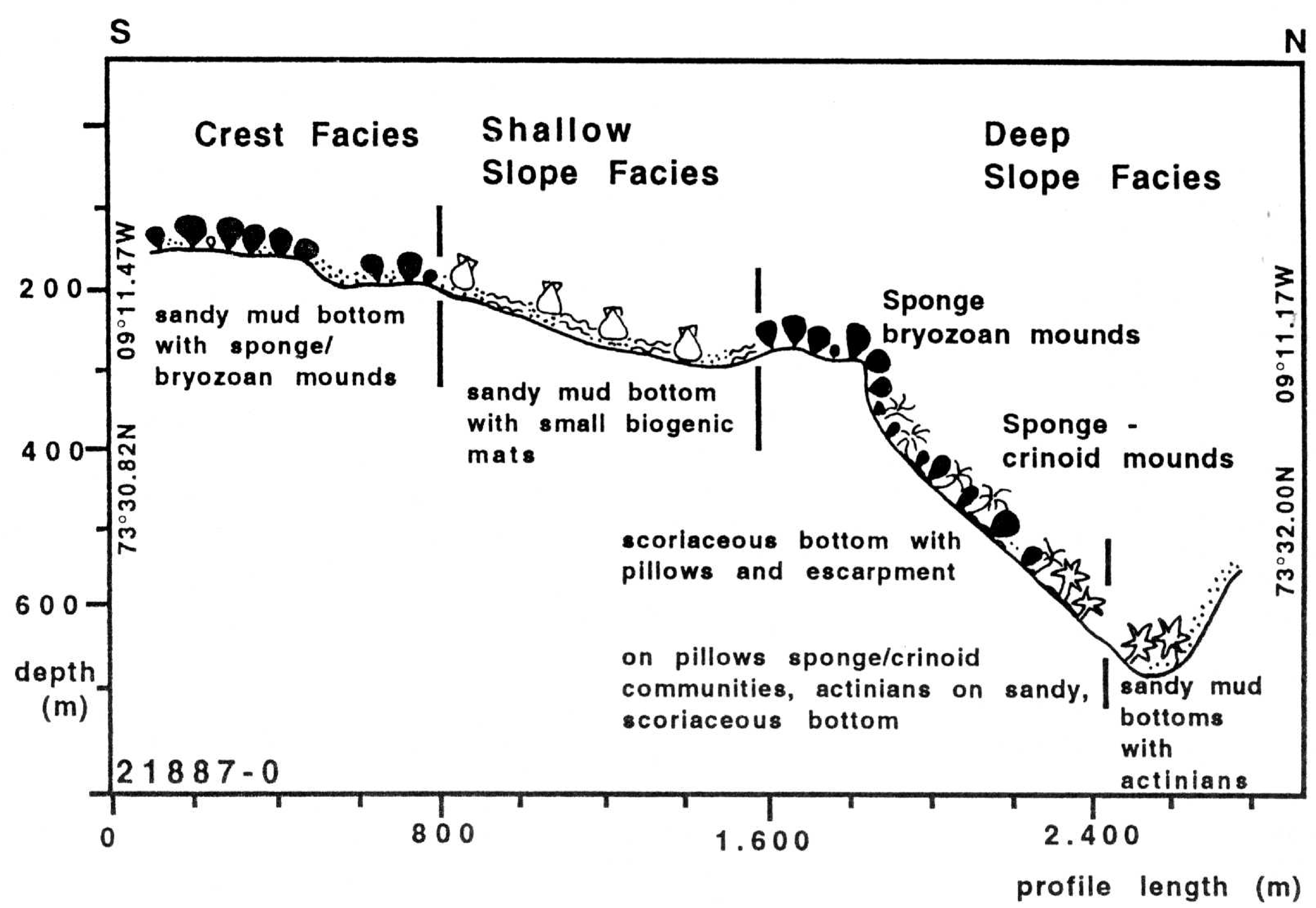

Fig. 8. Bathymetry and facies distribution along OFOS-track21887-0,northwestern slope. For legend see Fig. 6. 
biogenic mat; below it a thin volcanoclastic layer (thickness 0.5 to $2 \mathrm{~cm}$ ); and a Cibicides-sand layer at the base at least $12 \mathrm{~cm}$ thick (Pl. 22/2).

The overall construction of the uppermost biogenic mat is similar to that found on the ridge north of the western Jan Mayen Fracture Zone. Both mats show a dense meshwork of sponge spicules and branched bryozoan fragments. Nevertheless, there are major differences in the specific composition of the biogenic mats. While the mat from the ridge north of the Jan Mayen Fracture Zone is clearly dominated by sponge spicules bound by microbial activity (see above), the living surface of the biogenic mat sampled from the Vesterisbanken Seamount is composed mainly of living hydrozoan-bryozoan thickets and a few serpulids that colonize the spiculite mat below.

Hydrozoan colonies as well as surfaces and rootlets of branching, weakly calcified colonies of bryozoans (Notoplites normanni, Tricellaria gracilis) are colonized by Cibicides lobatulus and other bryozoans. The living bryozoan fauna also includes species with a dendroid growth form such as Palmicellaria skenei, with reticulate colonies such as Sertella elongata, and encrusting forms (Cribrilina watersi, Schizoporella porifera, Smittina glaciata). In addition, species such as Hornera lichenoides, Tessaradoma gracile, Crisia sp.,Porella plana,Porella compressa and tubuliporid species occur as complete colonies and colony fragments within the biogenic mat.

Another important observation is the high percentage of iron/manganese-stained bryozoan branches in the deeper meshwork below the living surface in the Vesterisbanken sample, possibly indicating a long period of exposure at or near the sea floor. However, because of the limited number of samples from both regions, the relevance of the compositional differences of the Vesterisbanken mat and the mat

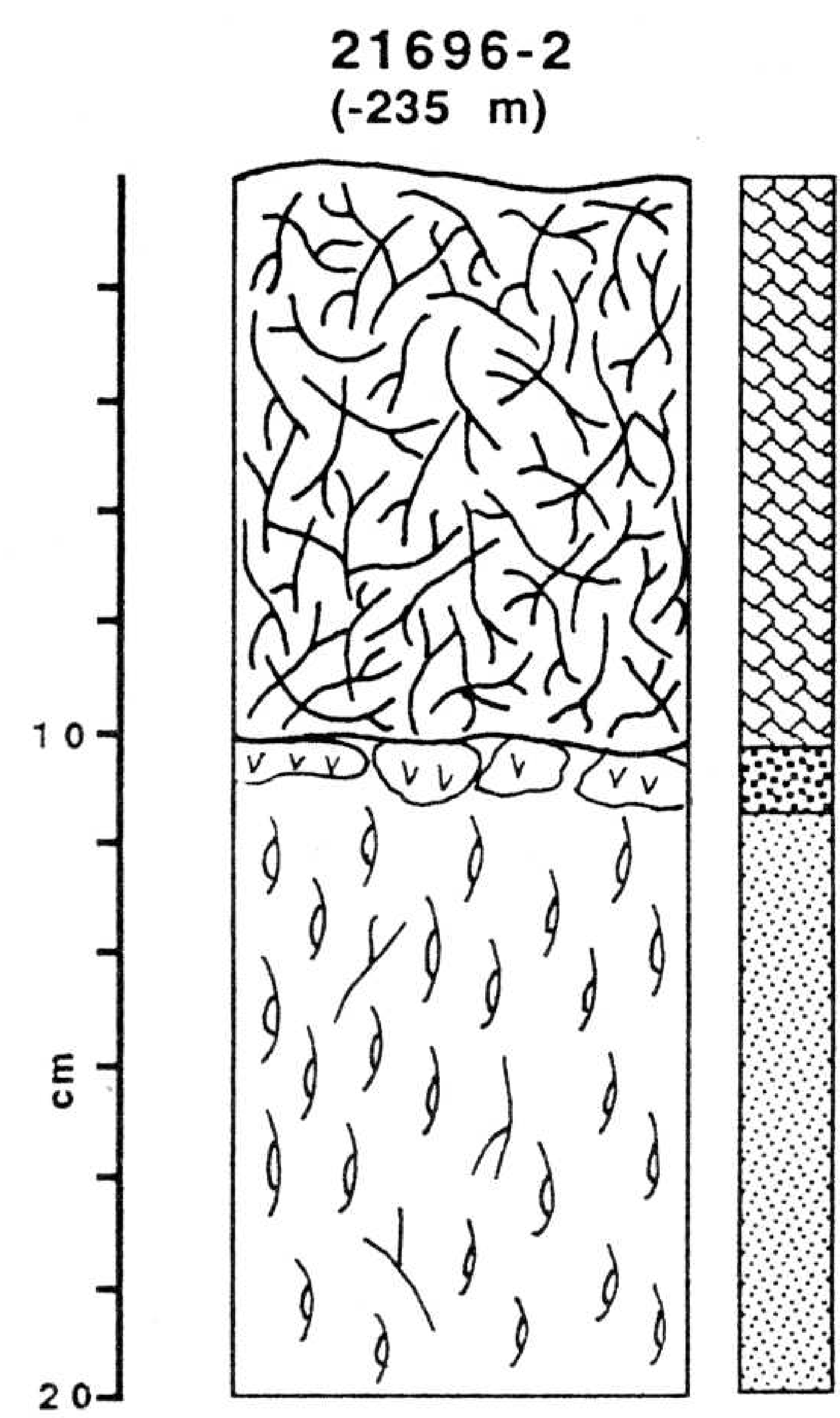

Components

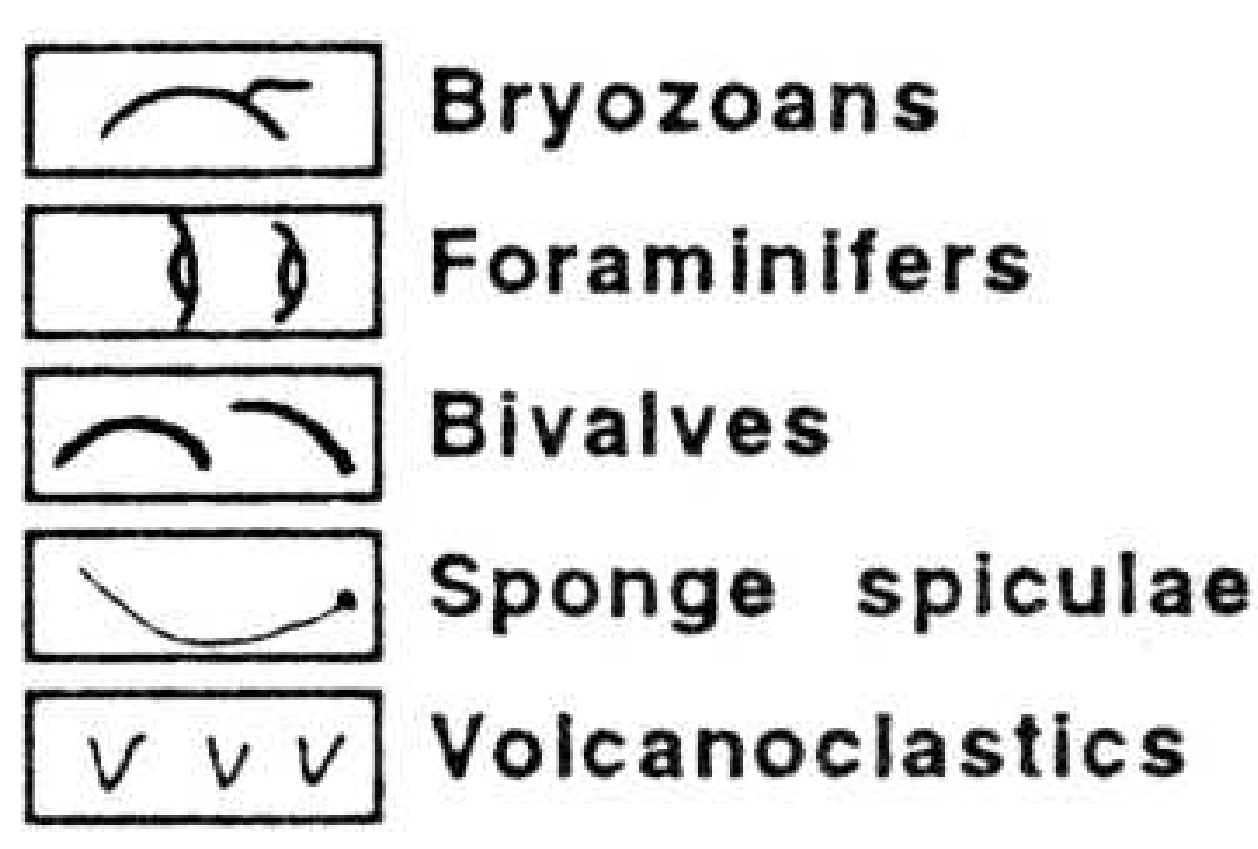

Texture

स्त्य Biogenic mat

Fif Gravel

Sand

$\therefore \vdots \vdots 3$ Sandy mud

….... Mud

Fig. 9. Depositional units and sediment textures of box core 216962 , southwestern slope, crest facies at $-235 \mathrm{~m}$.

on the ridge north of Jan Mayen cannot be clearly determined. It may be related to either local variability in composition of the mat caused by the relative proximity to a sponge buildup, or it may indicate fundamental differences in the formation of the mats.

The thin volcanoclastic layer is almost exclusively composed of rather fresh basaltic lapilli indicating a short period of volcanic activity.

The basal unit is a bioclastic sand layer with a high proportion of the benthic foraminifer Cibicides lobatulus (27.3 wgt. \%), bryozoan fragments ( 20 wgt. \%) dominated by heavily corroded and iron/manganese-stained Palmi-

Fig. 1. A section of a flat sponge bryozoan mound from OFOS track $21880-0$ at $-185 \mathrm{~m}$. "Core" sponges, such as Thenea cf. muricata $(\mathrm{TH})$ and Geodia $(\mathrm{G})$ rest on and within a rigid biogenic mat constructed by branched bryozoan fragments and sponge spiculae. The large core sponge in the central part of the photo is laterally colonized by bryozoans, Schaudinnia (S), and brittle star. Core sponges living within the biogenic mat cause updoming effects of the mat during growth (compare with P1.6/5). Additional faunal elements of the biogenic mat are endobenthic ascidians (ENDAS), whose paired openings are visible as small black dots on the mat surface. The surface itself provides habitat for lyssacine hexactinellid Schaudinnia rosea (S) and for yellow poecilosclerid (P) crusts (Mycale?). Furthermore, actinians (A), serpulids, brittle star and starfish complete the associated fauna. In the upper right corner a bryozoan fan is visible and a residual body (SR) of Schaudinnia is present in the upper left corner of the photo. The size of the photographed section is about $2 \mathrm{~m}^{2}$.

Fig. 2. A section of the biogenic mat with scattered sponges (poecilosclerid crusts $(\mathrm{P})$, geodiids $(\mathrm{G})$ ) and bryozoan overgrowth from OFOS track $21880-0$ at $-155 \mathrm{~m}$. The biogenic mat is densely colonized by endobenthic ascidians (ENDAS). The yellowish haloe in the upper central part is a hydrothermal emanation. The size of the photographed section is about $1 \mathrm{~m}^{2}$.

Fig. 3. A section of a flatcake sponge mound from OFOS track 21880-7 at $-172 \mathrm{~m}$. In contrast to the sponge bryozoan mounds (see Pl. 1/1) this mound type is formed by numerous, but flatcake-like Thenea (Th). In general, the flatcake sponge mounds cover areas of up to $10 \mathrm{~m}^{2}$., whereas sponge bryozoan mounds are smaller $\left(1-3 \mathrm{~m}^{2}\right)$. The mound surface is colonized by bryozoans, actinians (A), serpulids, small poecilosclerid crusts, and Schaudinnia rosea $(\mathrm{S})$. The size of the photographed section is about $2 \mathrm{~m}^{2}$. 

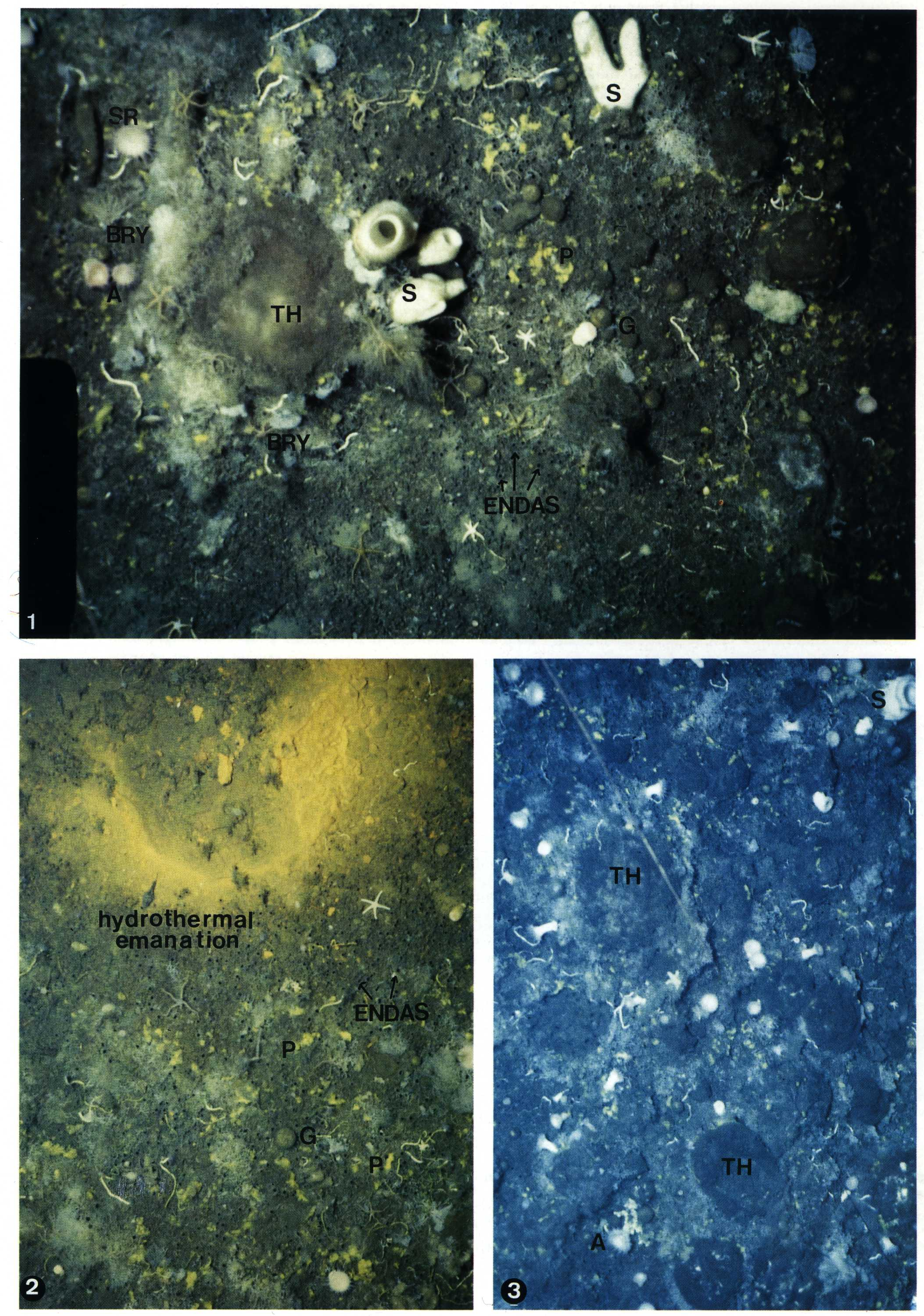
cellaria skenei colonies, bivalve fragments (10 wgt. \%), planktic foraminifers (8.6 wgt. \%), sponge spicules (3.8 wgt. \%), and admixtures of radiolarian frustules, pteropods, ophiuroid ossicles and serpulid remains. About one quarter of the particles are non-biogenic, predominantly of volcanoclastic origin (21.2 wgt. \%). According to its compositional variability and the good sorting, this bioclastic sand layer is clearly a current deposit with sediment input from various sources (volcanoclastic, various benthic habitats and surface waters).

A variety of autochthonous biogenic constructions have developed on the biogenic mat. Based on the information from the OFOS tracks, the following construction types of the biogenic buildups are evident:

A) Sponge supported buidups

-- small sponge-bryozoan-hydrozoan-serpulid mounds (1-3 $\mathrm{m}^{2}$ in size)

-- flatcake-like sponge-bryozoan mounds (about $10 \mathrm{~m}^{2}$ in size)

--elongated sponge-bryozoan hedges and spurs (several meters to tens of meters in length)

B) Bryozoan supported buildups

-- extended bryozoan-sponge thickets

C) Colonization of the semi-stabilized sandy mud

-- Actinian-serpulid-poecilosclerid sponge meadow.

The remaining areas between the buildups are covered by calcareous sandy muds and sand with abundant planktic and benthic foraminifers. A patchy concentration of foraminifers and other coarse particles indicates bottom current activity and winnowing of fine-grained deposits. On these rather instable sandy bottoms, a patchy colonization by actinians and serpulids is developed at several locations. A high population density of starfish and brittle stars is characteristic in all buildup types of the crest facies.
Small flat sponge-bryozoan-hydrozoan-serpulid mounds

Small flat mounds of 1-3 $\mathrm{m}$ in diameter are very common within the uppermost benthic zone. They do not rise more than 0.5-1 m above the sediment surface. In most cases, these mounds have a core of large domed demosponges of the Geodia-, Stelleta-, and/or Thenea-type (Pl. 18/1, Fig. 10). These ball or ovate sponges secrete rigid organo-spicular skeletons. The tetraxone megascleres are long $(>1-2 \mathrm{~cm})$ and occur within dermal layers of large microscleres (sterraster) in geodiids. The size of these sponges varies between $5-50 \mathrm{~cm}$; in some cases, giant specimens of more than $1 \mathrm{~m}$ were observed. Within the Thenea specimens giant forms are a combination of genetically similar buds which are fused together and lose their individual shape (STEENSTRUP $\&$ TENDAL 1982).

The most common sponge taxa in the mound core is Geodia barretti. Mature specimens are up to $50 \mathrm{~cm}$ diameter and approximately $30 \mathrm{~cm}$ height. Thenea $\mathrm{cf}$. muricata with a maximum size of $30-50 \mathrm{~cm}$ and long root-like protrusions at the base is also very common.

The margins of these large domed sponge assemblages are intensively overgrown by a diverse bryozoan fauna with a variety of different colony growth forms, long-shafted calcitic serpulid worm tubes, and hydrozoans. Dredge sample GIK 21880-5 taken from $-180 \mathrm{~m}$ to $-331 \mathrm{~m}$ reveals a predominantly fresh bryozoan fauna that is dominated by Diplosolen intricarius, Idmidronea atlantica var. gracillima, Palmicellaria skenei, Sertella beaniana, and the encrusting species Cribrilina watersi. All other species, such as diverse tubuliporid cyclostomes, Hornera lichenoides, Sertella elongata and others are of minor abundance. The associated sponge fauna is characterized by white chimney-like lyssacine rossellid hexactinellids of the taxon Schaudinnia (S. rosea). Very common in the vicinity of the core sponges are small $(2-5 \mathrm{~cm})$ yellow to grey ball-shaped Geodia specimens.

Fig. 1. A section of sponge bryozoan hedges and spurs in the crest facies (OFOS track 21880-0 at -152m). More than $10 \mathrm{~m}$ long spurs and hedges of dendroid, reticulate, and probably articulate bryozoan colonies (BRY) are alined perpendicular to the direction of slope inclination. The spurs rest on a biogenic mat which is colonized by small core sponges (CS), geodiids (G), actinians (A), and serpulids. The size of the photographed section is about $2 \mathrm{~m}^{2}$.

Fig. 2. A section of an actinian poecilosclerid sponge meadow in the crest facies (OFOS track 21880-7 at $-182 \mathrm{~m}$ ). Patches of calcareous sand are colonized by actinians (A), branched poecilosclerid (P) Clathria, and serpulids. The size of the photographed section is about $3 \mathrm{~m}^{2}$.

Fig. 3. A section of a small sponge bryozoan mound in the shallow slope facies (OFOS track 21880-0 at $-283 \mathrm{~m}$ ). The core sponge in the upper left is intensively overgrown by a bryozoan colony (BRY), probably by Sertella elongata. The volcanoclastic sediment is colonized by Cyclopecten (CP), Thenea (TH), Geodia $(\mathrm{G})$, poecilosclerid Clathria (PCL), and yellow poecilosclerid sponge crusts (Mycale?) (PY). The size of the photographed section is about $1.5 \mathrm{~m}^{2}$.

Fig. 4. Dark volcanoclastic sediments in the shallow slope facies (OFOS track 21880-0 at $-325 \mathrm{~m}$ ). The semistabilized substrate is densely colonized by Cyclopecten (CP), terebellomorph onuphid polychaetes (TBP), starfish (Solaster), and brittle star(Ophiopleura). Small bryozoan colonies (BRY) are attached to volcanoclastic pebbles. Not identified sponges (SP) and serpulid worm tubes are also present. The size of the photographed section is about $1 \mathrm{~m}^{2}$. 


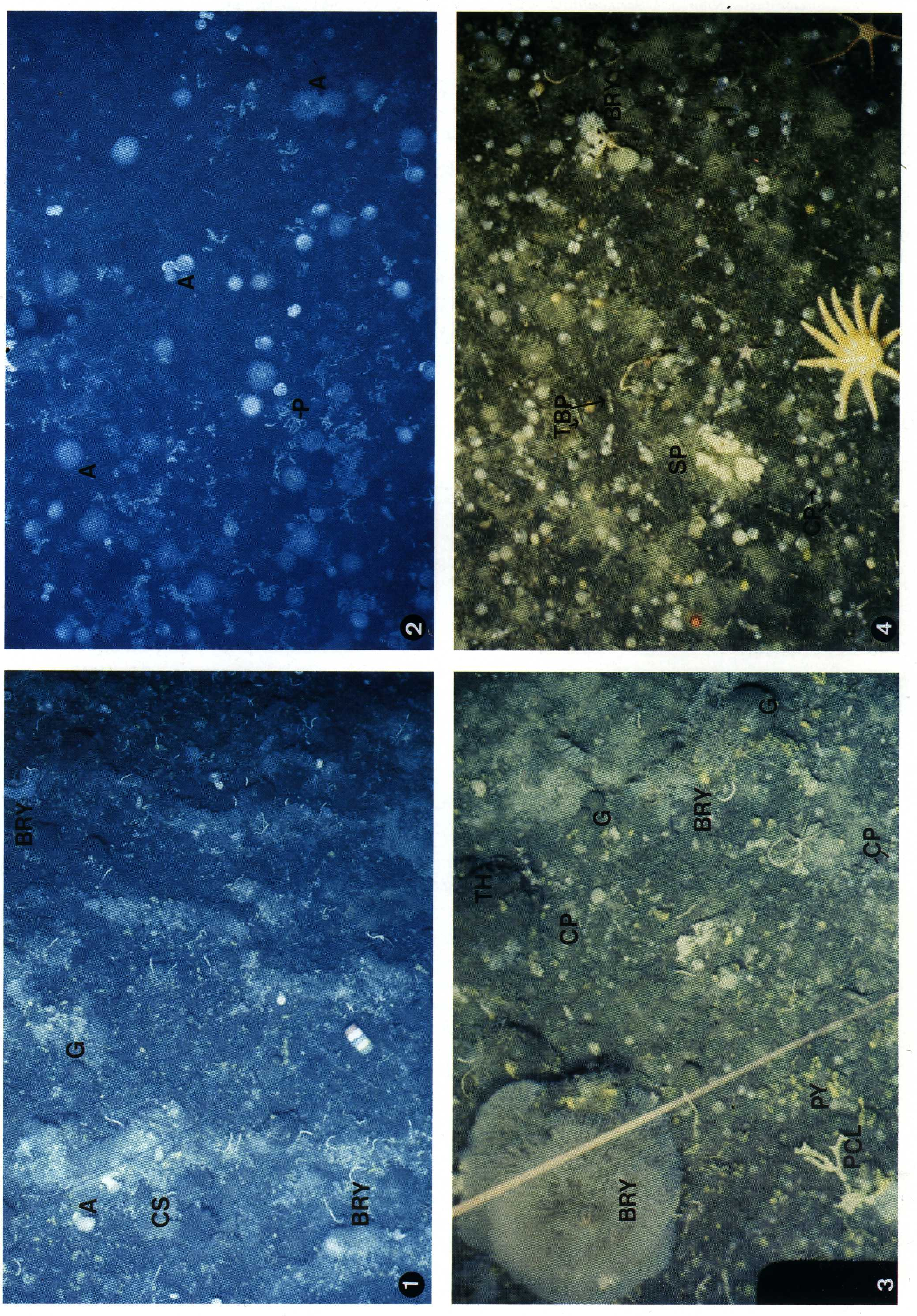


Geodia - Thenea - Schaudinnia - Bryozoa community (small flat sponge mound)

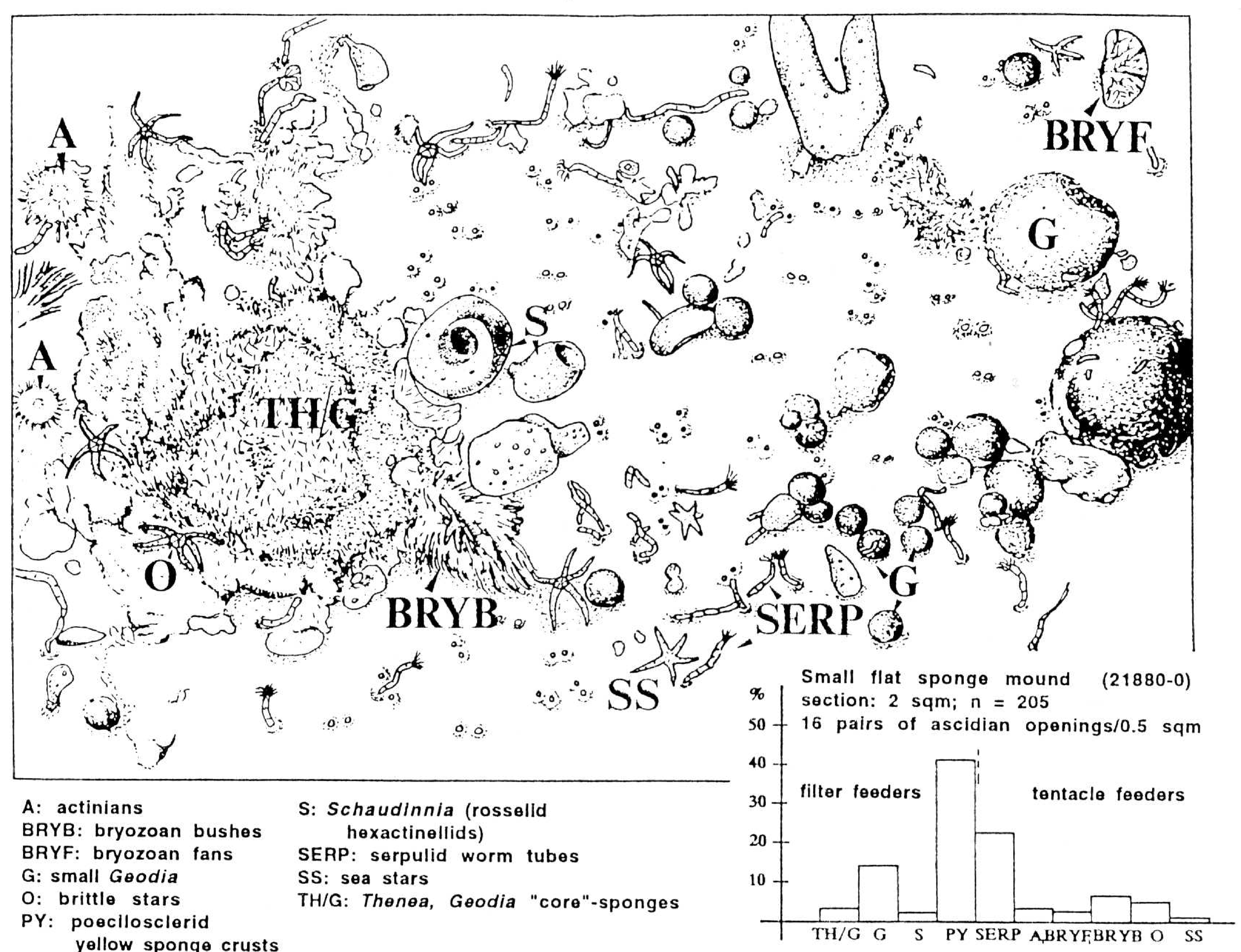

Fig. 10. Small flat sponge mound with statistical analysis of functional feeding groups for a representative sector in the crest facies (see Pl. 18/1).

Their grey colour results from finely grained organic "fluff" which is baffled by protruding spicules. Smaller pale yellow ball-shaped sponges may be related to the taxon Tethya. In addition, scattered bright yellow, small sponges form irregular crusts on the top of the spicule meshwork and core mound sponges. These crusts are related to the poecilosclerid taxon Mycalidae. Specimens of Tetilla and Polymastia with the characteristic papillae and white ball-shaped Suberites sp. with a single prominent oscular opening are present, but rare.

\section{Flatcake sponge-bryozoan mounds}

In contrast to the small flat mounds which exhibit one or two domed core sponges, the flatcake mounds exhibit

Plate 20

Vesterisbanken Seamount - Crest and deep slope bryozoan sponge thickets and sponge crinoid communities

Fig.1 A section of a bryozoan sponge thicket in the crest facies (OFOS track 21880-7 at -197m). Between -170 to $-200 \mathrm{~m}$, a dense bryozoan thicket covers the substrate completely. Bryozoans (BRY) are dominated by Sertella elongata which forms erect reticulate fans. Poecilosclerid Clathria (PCL), actinians (A), and serpulids live in this thicket. The size of the photographed section is about $2 \mathrm{~m}^{2}$.

Fig. 2. A section of a sponge bryozoan mound in the deep slope facies (OFOS track 21891-1A at $-450 \mathrm{~m}$ ). The core of these deep slope mounds are Thenea $(\mathrm{TH})$ and Geodia $(\mathrm{G})$ sponges. The mound surface is colonized by large poecilosclerid Clathria (PCL), yellow poecilosclerid crusts (Mycale?) (PY), Schaudinnia (S), fan-type bryozoan colonies (BRY), and serpulids. The size of the photographed section is about $2 \mathrm{~m}^{2}$.

Fig. 3. A section of a bryozoan thicket in the deep slope facies (OFOS track 21891-1C at -1.008m). The deep slope bryozoan thickets (BRY) are dominated by slender, dichotomously branching and reticulate growth forms, probably Idmidronea atlantica var. gracillima and Sertella elongata. The bryozoan thickets are associated with geodiid sponges (G), actinians (A), and large, blue ascidians (AS). The size of the photographed section is about $1.5 \mathrm{~m}^{2}$.

Fig. 4. A deep slope sponge crinoid mound (OFOS track 21891-1C at $-767 \mathrm{~m}$ ). Lava blocks provide hard grounds for settlement of Schaudinnia (S) aggregations. The chimney-like sponge is often used by Heliometra glacialis (HG) to get in elevated feeding position. The size of the photographed section is about $1.5 \mathrm{~m}^{2}$. 
numerous domed core sponges (Fig. 7,Pl. 18/3). The mounds are therefore larger ( $10 \mathrm{~m}$ diameter). The fixosessile benthic communities are similar in diversity and distribution to the small flat mounds.

\section{Sponge-bryozoan hedges and spurs}

Totally different in morphology to the mound structures are long (more than $10 \mathrm{~m}$ ) elongated spurs formed by aggregates of large domed core sponges that occur on the top plateau of the seamount (Fig. 6, Pl. 19/1). These spurs are oriented longitudinally to the seamount slope. They are partly interrupted and resemble the overall morphology of ripple fields. The geometry of the elongated spurs reflects the predominant arrangement of domed sponges in long rows. The spur crests are densely covered of small bryozoan colonies. As can be judged from the photographs, the bryozoan fauna consists of a variety of dendroid, reticulate, and probably articulate taxa. As inferred from comparision with nearby bryozoan-hydrozoan communities, the spur crest community may also include hydrozoans. Conspicuous, however, are the low numbers of lyssacine hexactinellids in comparison to sponge-bryozoan mounds. Long-shafted serpulid worm tubes are also present. The initiation of these spurs is unclear. It might be related to earlier bottom current activity that caused the formation of ripple fields in the topmost region of the seamount, or it might reflect surface flow structures of lava sheet flows. Once created, the relief of the spur crests provided favorable conditions for filterand tentacle-feeding fixosessile benthic communities.

\section{Bryozoan-sponge thickets}

An accumulation of dense bryozoan meadows was observed on a steep margin at $-170 \mathrm{~m}$ to $-200 \mathrm{~m}$ (OFOS track 21880-7, Fig. 7). The bryozoan colonies grow on large core sponges and on the flat seafloor, often covering the substrate completely (Pl. 20/1). Judging from photographs, the bryozoan fauna seems to be dominated by Sertella elongata forming prominent upright reticulate fans. Additional taxa are lyssacine hexactinellids (Schaudinnia rosea), serpulids, branched white haplosclerid demosponges, and yellow irregular poecilosclerid demosponges (Mycale?) attached to bryozoan colonies. Actinians were rarely found in this subfacies. Endobentic activity, indicated by open tubes in the substrate, was observed only locally.

\section{Actinian-serpulid-poecilosclerid meadow}

Occasionally, an actinian cluster is seen on a thin cover of calcareous sand (Fig. 7, Pl. 19/2). Actinians and serpulids dominate this facies. Additional faunal components are branched white, poecilosclerid Clathria, rare geodiids and few lyssacine hexactinellids (Schaudinnia sp.).

\subsubsection{The Shallow slope facies}

The upper flanks of the Vesterisbanken Seamount are covered by sediments and small biogenic buildups of the shallow slope facies from $-260 \mathrm{~m}$ to approximately $-400 \mathrm{~m}$. Most characteristic of this facies belt is a high abundance of thin-shelled valves of Cylclopecten imbrifer and Cyclopecten graui (Pl. 19/3-4). The seafloor over wide areas is smooth and covered by semi-stabilized sandy mud bottom and/or dark fine-grained volcanoclastic sediment. Small elevations locally rise from the steeply inclined but smooth-structured seafloor and are colonized by sponge-bryozoan buildups. In addition, small sponge-bryozoan mounds are randomly scattered on the sand and sandy mud bottoms. The basaltic basement crops out only occasionally at the surface. From the OFOS-underwater TV records and colour slides there is the overall impression that volcanic structures on the upper flanks of the Vesterisbanken are more extensively buried by a volcanoclastic-bioclastic sediment cover of variable thickness than at the top. Vertical successions of lithologic units from two box corers support this assumption:

(1) Box core GIK 21886-3 (Fig. 11), recovered at $-260 \mathrm{~m}$ from the northeastern flank of the seamount contains two sedimentary units, both of which contain brownish mixed

Fig.1. Hyalonema-Rosselidae-Cladorhiza-Thenea community (OFOS track 21883-0 at $-1.684 \mathrm{~m}$ ). The sponges (amphidiscophorid hexactinellid Hyalonema (HY), rosselid hexactinellid Schaudinnia (S), poecilosclerid Cladorhiza (CL), and Thenea (TH) core sponge) settle on a pillow lava block. In the upper right corner, a downslope volcanoclastic mass flow sediment is visible. The dislocated pebbles are colonized by rapid growing actinians (A). The size of the photographed section is about $1.5 \mathrm{~m}^{2}$.

Fig. 2. Hyalonema-Rosselidae-Cladorhiza-Thenea community (OFOS track 21883-0 at $-1.631 \mathrm{~m}$ ). Only the steep inclined margins of the lava block are colonized (abbreviations see Pl. 4/1). The size of the photographed section is about $1.5 \mathrm{~m}^{2}$.

Fig. 3. Hyalonema-Rosselidae-Cladorhiza-Thenea community (OFOS track $21883-0$ at $-1.715 \mathrm{~m}$ ). The community colonized an isolated lava block. The strange poecilosclerid Cladorhiza (CL) is well visible in the center. Small depressions on the lava block are covered by a thin veneer of sand enriched with Pyrgo (PT) (abbreviations see Pl. 4/1). The size of the photographed section is about $1 \mathrm{~m}^{2}$.

Fig. 4. Caulophacus-Hyalonema-Cladorhiza-Thenea community (OFOS track 21883-0 at $-1.850 \mathrm{~m}$ ). The lyssacine hexactinellid Caulophacus arcticus grows on Thenea (TH). The basal parts of the funnel shafts are dark grey, resembling residual structures. Abbreviations see $\mathrm{Pl} .4 / 1$. The size of the photographed section is about $2 \mathrm{~m}^{2}$. 

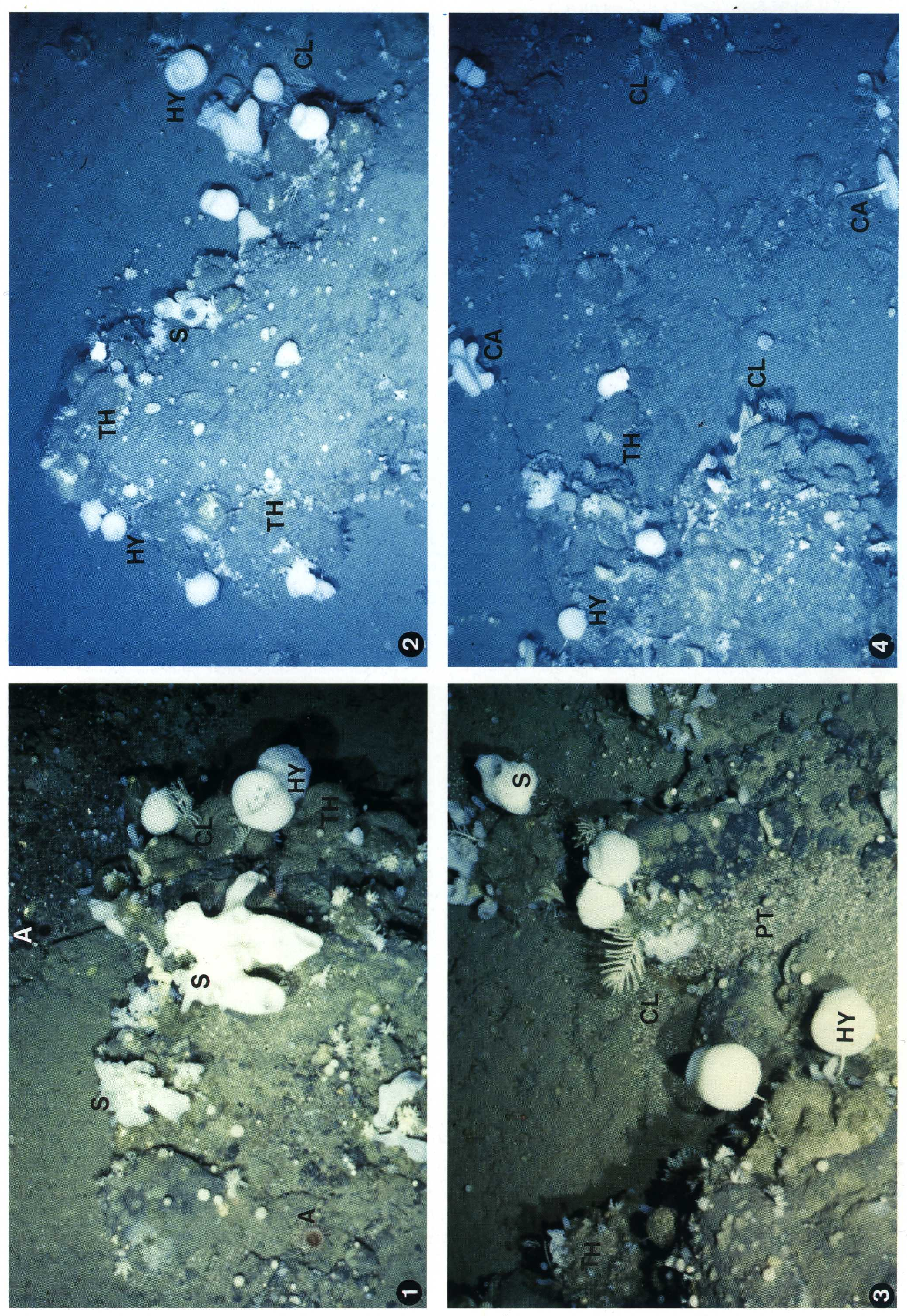


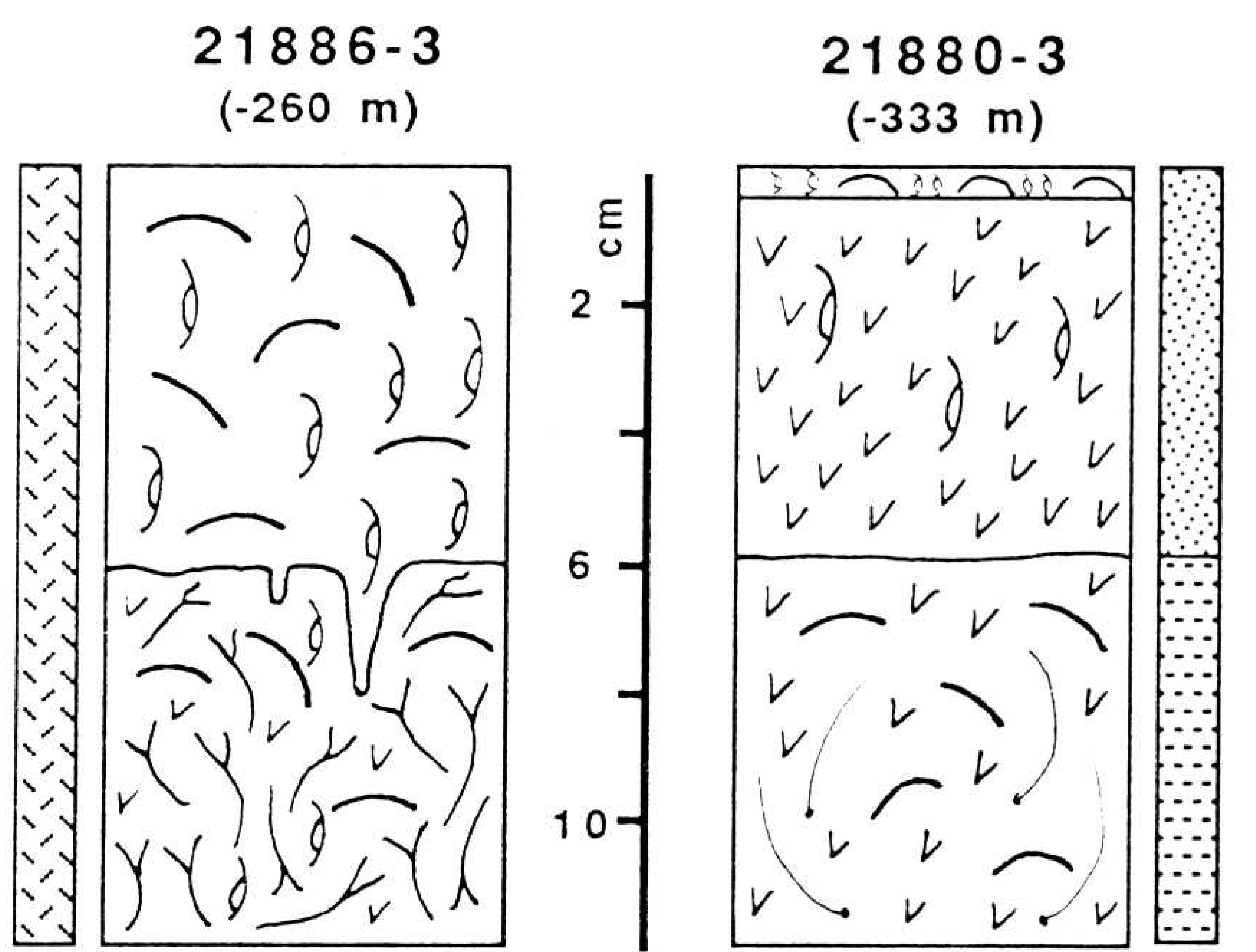

Fig. 11. Depositional units and sediment textures of box cores from the shallow slope facies, northeastern slope. Legend see Fig. 9.

biogenic-terrigenous sandy mud. The 6-cm-thick surface layer is composed predominantly of benthic $(28 \mathrm{wgt} . \%)$ and planktic $(27.7 \mathrm{wgt}$. \%) foraminifers. Other important components are valves and shell debris (20.7 wgt. \%) of $\mathrm{Cy}$ clopecten, Limatula and branched bryozoan fragments (13.7 wgt. \%). Among the latter, Tubulipora cf. ventricosa is the most common species, followed by Sertella elongata, Tessaradoma gracile, Idmidronea atlantica var. gracillima, Hornera sp., and Palmicellaria skenei. In addition, rare fragments of species such as Porella plana, Porella aperta, Pseudoflustra sinuosa, Leieschara subgracilis, and the encrusting species Schizoporella thomsoni and Disporella sp. complete the bryozoan fauna. Minor amounts of sponge spicules (4.4 wgt. \%) and volcanoclastic components (5.5 wgt. \%) also occur.

The underlying biogenic layer shows a clear predominance of branched bryozoan fragments (47.4 wgt. \%). Shell debris (25.5 wgt. \%), including Cylclopecten and Limatula, planktic (10.9 wgt. \%) and benthic (7.9 wgt. \%) foraminifers and sponge spicules ( $7.5 \mathrm{wgt} . \%)$ are found in considerably lower amounts, and volcanoclastic components (0.8 wgt. \%) occur only as admixtures.

Both sedimentary units display about the same spectrum of particles, which are derived from various sources. Sponge spicules and branched bryozoan fragments can be related to sponge-bryozoan buildups. Planktic foraminifers are supplied from surface waters. Benthic foraminifers contain a high proportion of epibenthic species which are typical of the sponge-bryozoan buildups. In addition, there is the volcanoclastic source from the seamount itself.

In conclusion, most of the particles are not embedded insitu but are derived from downslope transport and/or bottom current activity. The compositional variability of both units indicate variations in supply from different sources. Because of the high percentage of coarse particles, both units represent semi-stabilized sandy mud bottoms. A variable balance of processes explains the differential compositions, e.g. downslope transport of fine-grained particles (predominantly terrigenous mud), vs. partial infiltration of fine-grained sediment in the organic meshwork and winnowing of fine material at the surface by bottom currents.

(2) The second box core (GIK 21880-3) was recovered at $333 \mathrm{~m}$ from a more southerly position on the northeastern flank of the seamount. Despite its proximity to the first box core sample, it depicts a different lithologic composition (Fig. 11). The vertical profile shows three depositional units from top to bottom:

1. Unit A, a surface layer a few millimeters thick with abundant planktic and benthic foraminifers, valves of Cyclopecten, ophiuroids and agglutinating onuphid polychaetes in addition to dark volcanoclastic grains. The dark sediment surface exhibits bioturbation where white foraminifer sand was disturbed by endobenthic organisms. About $90 \%$ of the isolated valves of Cyclopecten are agglutinated by an errant onuphid polychaete. The valves are fixed on the organic worm tube with the convex side outside. Each single tube has not more than five isolated valves on the dorsal and ventral sides. Apart from protective advantages, this agglutinating mode probably has the function of a ski to enlarge the contact-area to the semi-stabilized bottoms.

2. Unit B is a 6-cm-thick pyroclastic sand (61.2 wgt. \%), which contains considerable amounts of planktic (22.8 wgt. \%) and benthic foraminifers ( $12 \mathrm{wgt} . \%)$ and a small amount of sponge spicules (3.9 wgt. \%).

3. Unit $\mathrm{C}$ is a mixed sandy biogenic and volcanoclastic mud with 33.9 wgt. \% of volcanoclastic components, 20.4 wgt. \% bivalve debris (mostly Cylclopecten), $19.5 \mathrm{wgt}$. $\%$ sponge spicules, $13.2 \mathrm{wgt}$ \% planktic foraminifers, and $13 \mathrm{wgt}$. \% benthic foraminifers.

In a comparison of both cores the presence of a 6-cmthick volcanoclastic layer near the surface is striking. We infer, that during a relatively young eruption the seamount had been covered with volcanoclastic deposits. Later on, the volcanoclastics were eroded in wide areas and dispersed by downslope transport.

Most of the biogenic buildups in the shallow slope facies are similar to the buildups of the crest facies. Within OFOS track 21891-1A a sponge-bryozoan buildup with a typical Geodia-Thenea-Schaudinnia-bryozoan community is
Fig. 1.

Fig. 2.
Surficially cemented volcanoclastic mass flow at $-1.150 \mathrm{~m}$. The size of the photographed section is about $3 \mathrm{~m}^{2}$. Cibicides sand underlying a biogenic mat in the crest facies (box core 21696-2 at -235 m). The peak of the sand fraction $(250-500 \mu \mathrm{m})$ is dominated by Cibicides lobatulus $(\mathrm{C})$. Further constituents are Neogloboquadrina pachyderma tests $(\mathrm{N})$, bivalve fragments (BV), bryozoans $(\mathrm{B})$, and volcanoclastic particles $(\mathrm{V})$. The scale bar is $0.5 \mathrm{~mm}$. 
developed on a morphological high on the seamount slope (Fig. 12). Locally large bryozoan colonies of Idmidronea atlantica var. gracillima use larger sponges as a substrate for colonization. Cyclopecten was not observed within the sponge-bryozoan buildups.

\subsubsection{The Deep slope facies}

The deeper flanks (below $-400 \mathrm{~m}$ ) of the seamount provide more different substrates than the crest and shallow slopes because of their more complex morphologic structure. Volcanic foundations crops out over long distances with steeply inclined slopes. Here, the seafloor is covered by typical depth-related hard-substrate community zones. At other places, a thick cover of volcanoclastic sediments has accumulated. Downslope sediment mass dislocation (debris flows, turbidites, volcanoclastic breccias (Pl. 22/1)) indicates volcanotectonic disturbances or slope instability. Stabilization of the uppermost sediments is indicated by lightcoloured surficial lithified crusts, which appear just a few centimeters below the sediment surface within slide scars (Pl. 22/1). Other extensive substrates are soft bottoms and unstable sand/sandy mud bottoms.

The large variety of seafloor substrates is reflected by a high variability of faunal assemblages and sedimentary facies. These deep slope communities can be grouped into:
A) Hard rock related assemblages

- deep slope sponge-bryozoan mounds

- deep slope sponge-crinoid mounds

- deep slope bryozoan thickets

- deep slope sponge mounds and volcanoclastic sediments

B) Soft bottom related assemblages

- deep slope soft bottom Bathycrinus community

Deep slope sponge-bryozoan mounds $(-300 \mathrm{~m}$ to $-500 \mathrm{~m})$

Near the lower boundary of the shallow slope facies on the upper seamount flanks slope inclinations increase drastically. Along OFOS track 21891-1A (Fig. 12), spongebryozoan mounds were observed almost completely covering the deep southern slope. Huge bryozoan bushes and fan-type bryozoans have overgrown sponge mounds (Pl. 20/2). The irregular surface of the mounds are formed by large core sponges, mainly large Geodia sp. and Thenea cf. muricata. Lyssacine hexactinellids (Schaudinnia) are rare. The bryozoans are partly penetrated with yellow poecilosclerid sponges (Mycale sp.). Very common are bushes of branched, horn-shaped sponges which may be related to the poecilosclerid Clathria and to a haplosclerid (Chalina ?). The large core sponges are covered with dark grey fine-grained matter. Most large demosponges and hexactinellids exhibit a dark grey base and a white top that indicates active growing tips during the Arctic summer, probably because of increased

Network of large parautochthonous tetractinellid and lyssacine hexactinellid spicules from the uppermost sediment surface. The inner pore space of the spicule network is still open and percolated by oxygenated water. SEM micrograph. This sample was taken from a ridge north of Jan Mayen in the Greenland Sea ("Dorothee's Nose) at $-600 \mathrm{~m}$ (also Figs. 3, 4, 6). Scale bar $=1 \mathrm{~cm}$.

Fig. 2. SEM micrograph from a network of large demosponge and hexactinellid spicules associated with bryozoans and serpulid worm tubes. Vesterisbanken Seamount at $-400 \mathrm{~m}$. Scale bar $=1 \mathrm{~cm}$.

Fig. 3. SEM micrograph of a critical point dried microbial envelope attached on a large sponge spicule. The envelope exhibits a lot of coccoid bacteria (arrow). Scale bar $=25 \mu \mathrm{m}$.

Fig. 4. Transmission light micrograph (TM) of methylenblue/ red fuchsine stained microbial colonies on a foraminifera test (arrows). The test is surrounded by an organic fluff that is accumulated in deeper areas of the spicule network (approximately $20 \mathrm{~cm}$ below the surface). In this area, the pore space is partly filled with degraded organic material. Scale bar $=50 \mu \mathrm{m}$.

Fig. 5. Young specimen of the tetractinellid demosponge Craniella sp. growing on a spicule within the spicule network (approximately $20 \mathrm{~cm}$ below the surface). The sponge larvae moved in the open pore space of the spicule network and settle down on certain spicules that were probably enveloped by specific microbes that could stimulate metamorphosis of the larvae. Therefore, the sponges grow within the spicule network. This behaviour explains the updomed structures of the biogenic mats which are shown in Pl. 18/1 and 18/3. Additionally, this phenomenon explains the formation of autochthonous spicule enrichments (spiculites). SEM micrograph, scale bar $=200 \mu \mathrm{m}$.

Fig. 6. TM micrograph of a very young demosponge Thenea sp. immediately after metamorphosis. The sponge settles on a large spicule with special root structure linked to a thin microbial envelope (arrow). Scale bar $=$ $200 \mu \mathrm{m}$.

Fig. 7. Relics of the rigid spicular skeleton of the hexactinellid Chonelasma sp. $10 \mathrm{~cm}$ below the sediment surface. The axial filament canals of the spicules are enlarged by bacterial activity (A). The surfaces of the spicules are partly covered by bacteria-induced ferroan hydroxides (B). The space between the spicule network is filled by an organic fluff and aggregated mostly by coccoid bacteria $(\mathrm{C})$. A young sponge is growing on a spicule (SP). Locality as in Fig. 1. Scale bar $=50 \mu \mathrm{m}$

Fig. 8. Surface of a large demosponge spicule completely covered by a sheet of filamentous bacteria. The spicule was collected $2 \mathrm{~cm}$ below surface. The space between the spicules is open and in this part of the spicule network run by surface water. Locality as in Fig. 1 . Scale bar $=2 \mu \mathrm{m}$ 

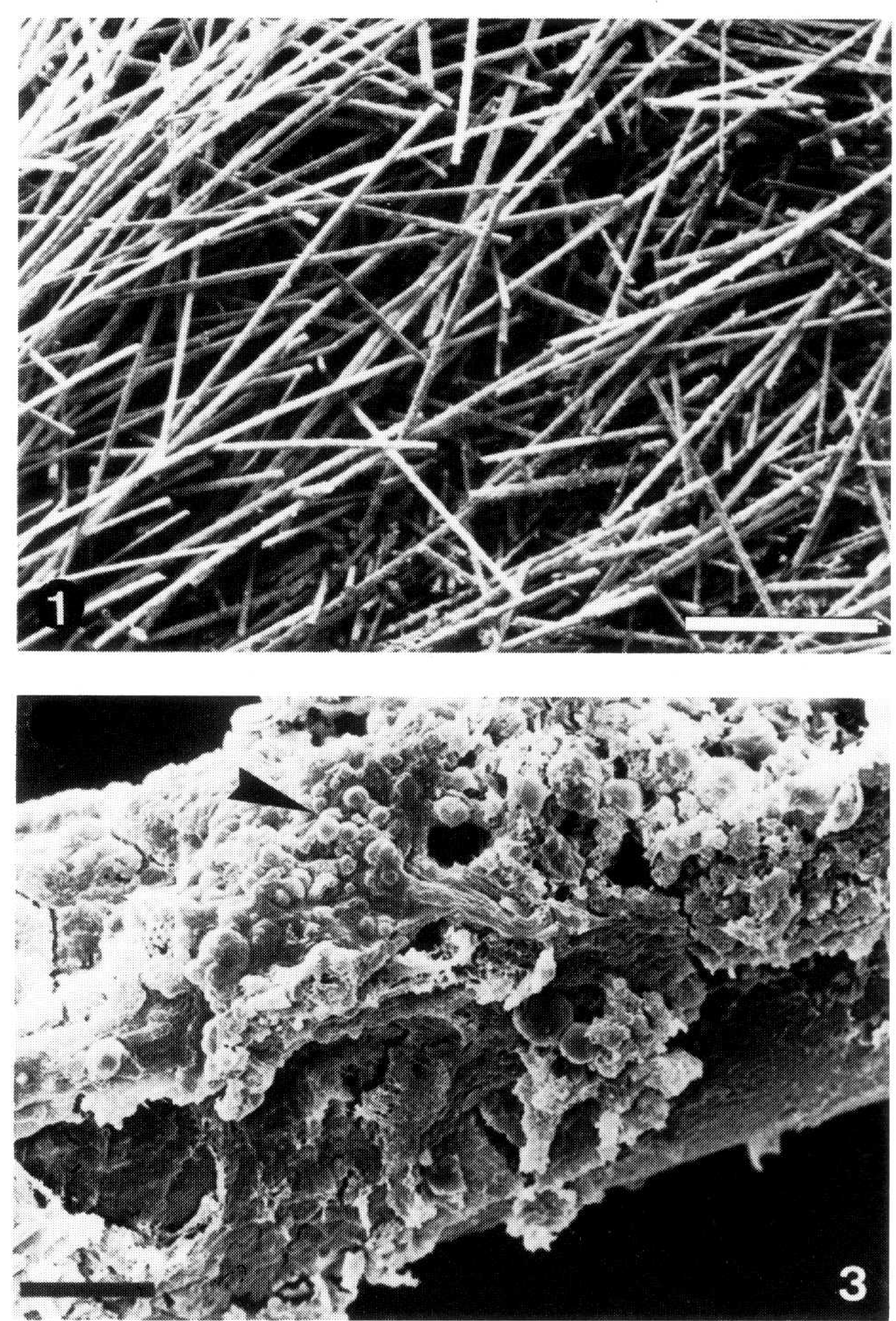

(3)

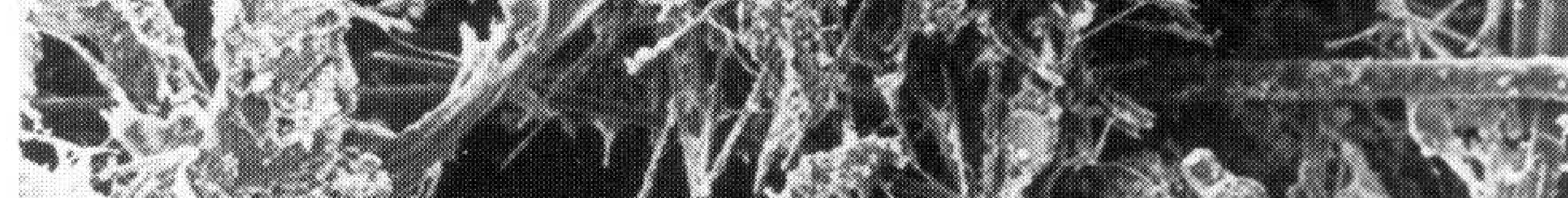

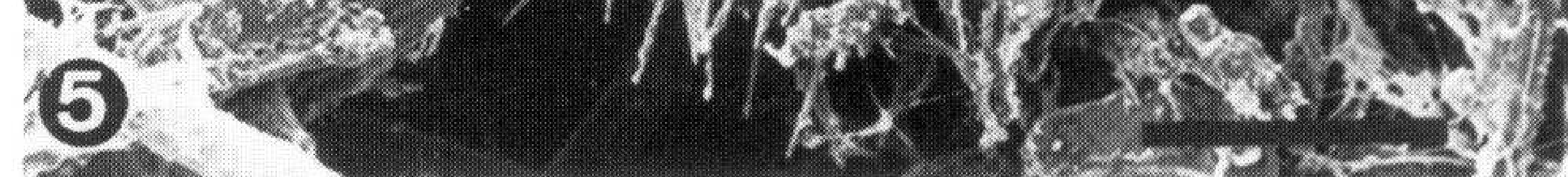

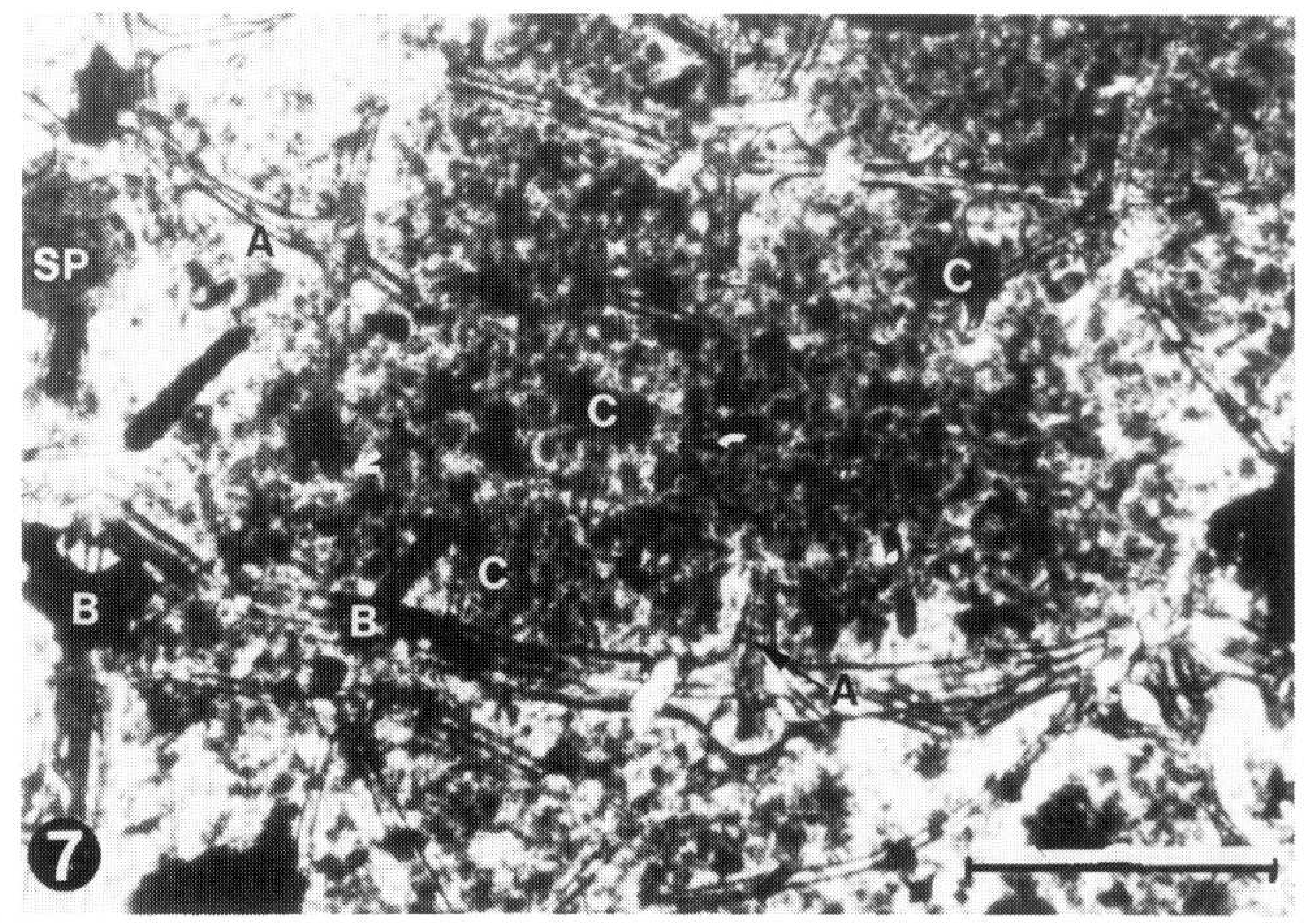

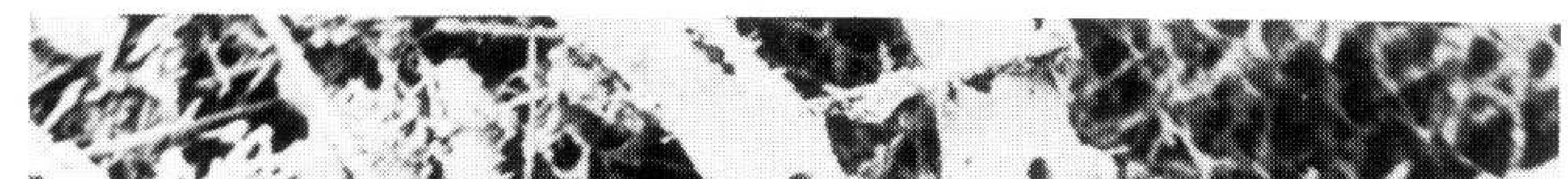
(2)
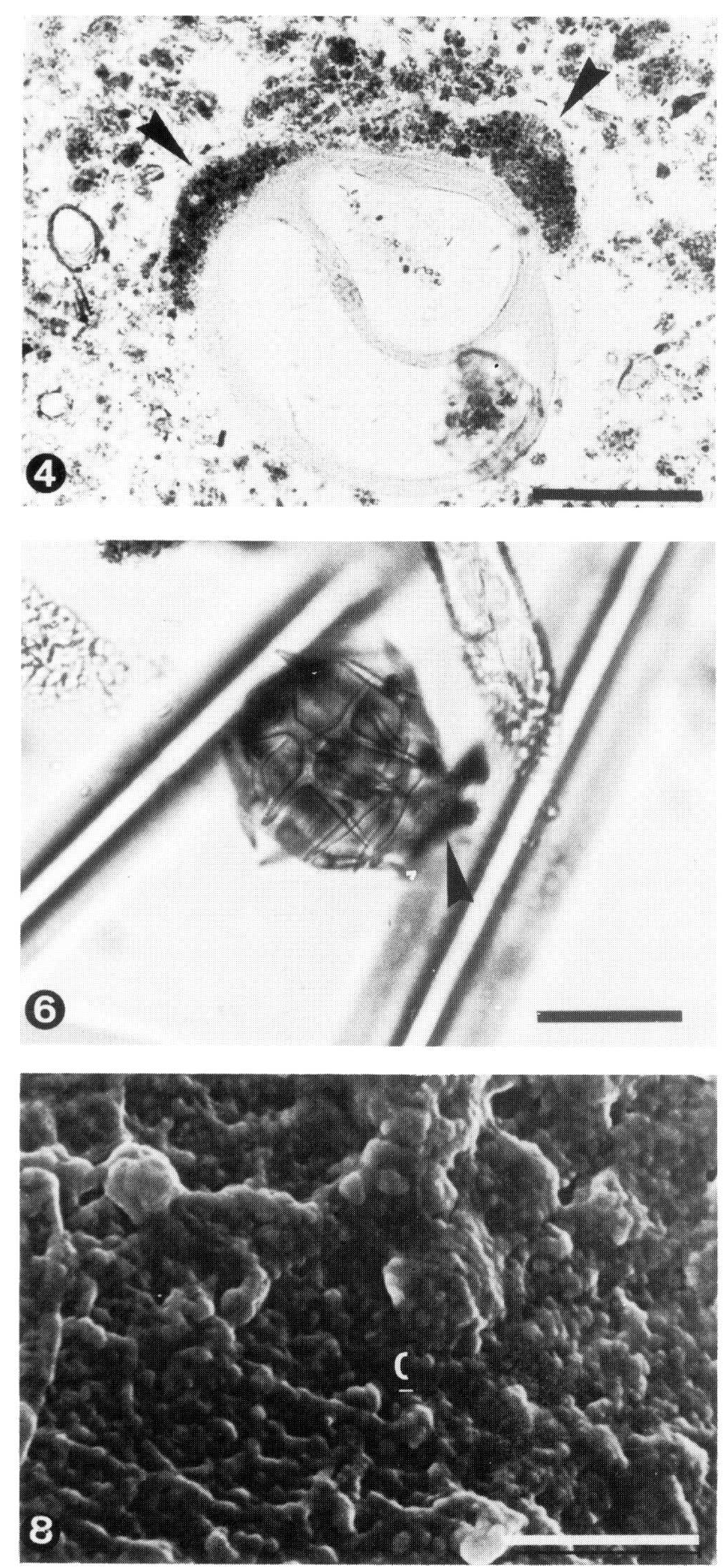


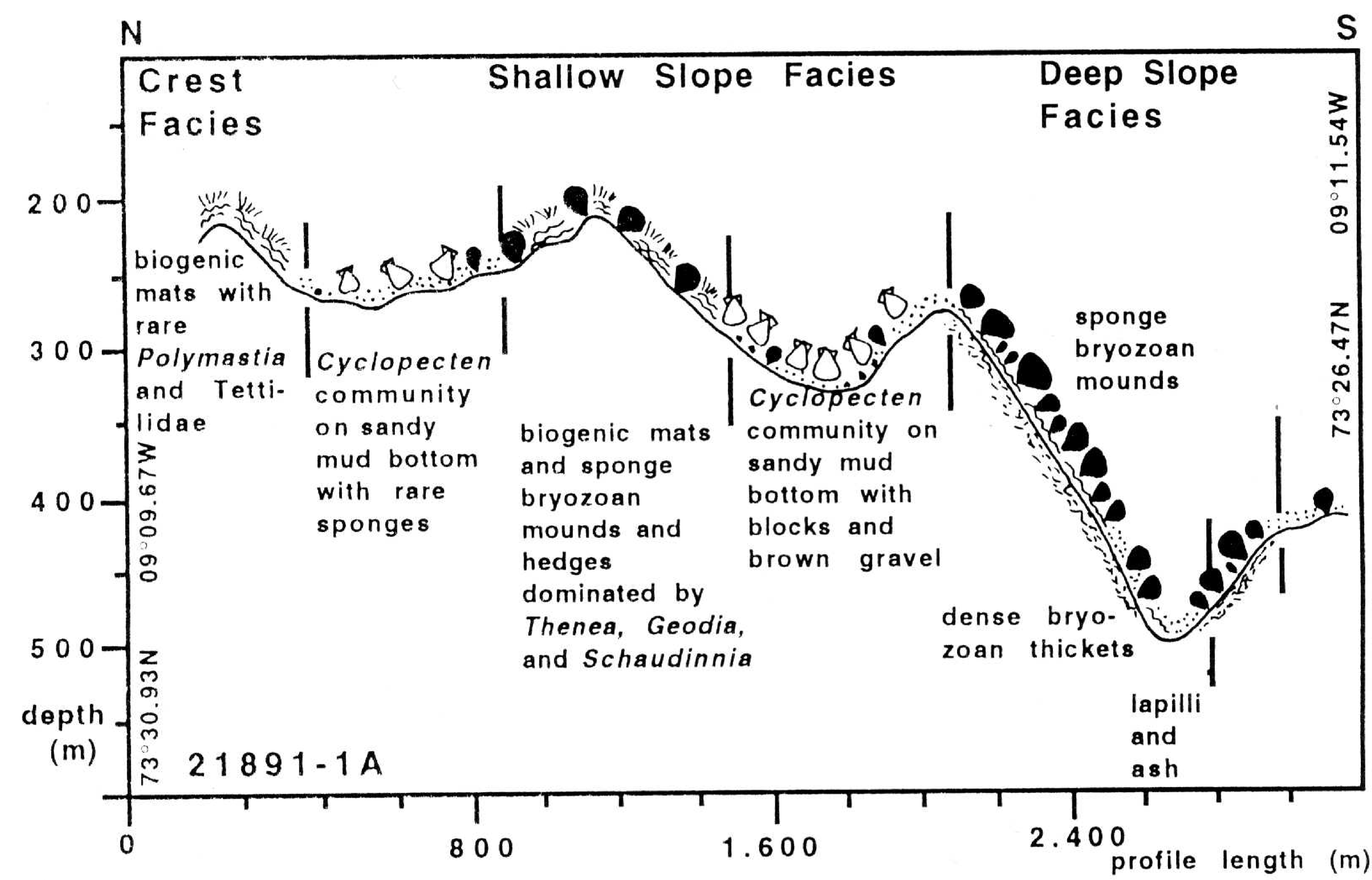

Fig. 12. Bathymetry and facies distribution along OFOS-track 21891-1A, upper southern slope. Legend see Fig. 6.

nutrient supply. The dark parts may either represent dead portions of the sponge skeleton or they may be related to residual bodies which the sponge produces to survive the Arctic winter. Haul samples (GIK 21891-1) taken from -276 $\mathrm{m}$ to $-854 \mathrm{~m}$ contain a characteristic bryozoan fauna dominated by Palmicellaria skenei, Idmidronea atlantica var. gracillima, Hornera lichenoides, and Diplosolen intricarius and is completed by Sertella elongata, tubuliporid cyclostomes, Crisia sp., and Cribrilina watersi, all of which (except $C$. watersi) occur with erect, arborescent or reticulate colony growth forms. Fan-like, extremely thinly branched colonies visible on several photographs at this depth zone may be the weakly calcified, articulate bryozoan Crisia sp.

\section{Deep slope sponge-crinoid mounds $(-750 \mathrm{~m}$ to $\mathbf{- 1 . 0 7 5} \mathrm{m})$}

The steep southern slope of the seamount depicts numerous small sponge-crinoid mounds along OFOS tracks 21891-1B and 1C (Fig. 15) at $-750 \mathrm{~m}$ to $-1.075 \mathrm{~m}$. The seafloor surface is dominated by lava rocks, partly covered by a thin layer of sandy mud within small depressions. Small lyssacine hexactinellid (Schaudinna) settle together with Clathria bushes and some actinids on pillow lava blocks. Sponge residual bodies are common. The vagile crinoid Heliometra glacialis commonly fixes its roots on the large chimney-like specimens of Schaudinnia cf. rosea (Fig. 14, $\mathrm{Pl}$.20/4). Heliometra glacialis was observed most frequently within the deep slope facies.

On the bioturbated soft bottoms of the small depressions, erect fixosessile organic and partly agglutinated worm tubes are quite common. Sponges are rare, only isolated specimens of Polymastia occur.

\section{Deep slope bryozoan thickets $(-1.008 \mathrm{~m}$ to $\mathbf{- 1 . 1 3 7} \mathrm{m})$}

Deep slope bryozoan thickets cover the volcanic foundation within a steep V-shaped gully (Fig. 15). Judging from photographs, mainly slender, dichotomously branching and reticulate colony growth forms occur, probably formed by Idmidronea atlantica var. gracillima and Sertella elongata.

Fig. 1. Idmidronea atlantica var. gracillima (Busk); box core 21696-2. x 25

Fig. 2. Diplosolen intricarius (S MIтH); box core 21696-2. x 60

Fig. 3. Tubulipora sp.; box core 21696-2. x 35

Fig. 4. Hornera lichenoides (LinNAEus); box core 21696-2. x 25

Fig. 5. Tubuliporid cyclostome; box core 21696-2. x 25

Fig. 6. $\quad$ Crisia sp.; box core 21696-2. x 24

Fig. 7. Notoplites normanni (NoRDGAARD); box core 21696-2. x 50

Fig. 8. Palmicellaria skenei (Ellis \& SOlANDER). x 80

Fig. 9. Tessaradoma gracile (SARS); box core 21696-2. x 60

Fig. 10. Tricellaria gracilis (VAN BEX NEDEN); box core 21696-2. x 95

Fig. 11. Sertella elongata (SMIT); $x 35$

Fig. 12. ?Megapora rigens (Busk). $\mathrm{x} 120$

Fig. 13. Cribrilina watersi ANDERson; box core 21696-2. x 90

Fig. 14. Smittina glaciata (WATERs); box core 21696-2. x 60

Fig. 15. Schizoporella porifera (SмITT); box core 21696-2. x 120 

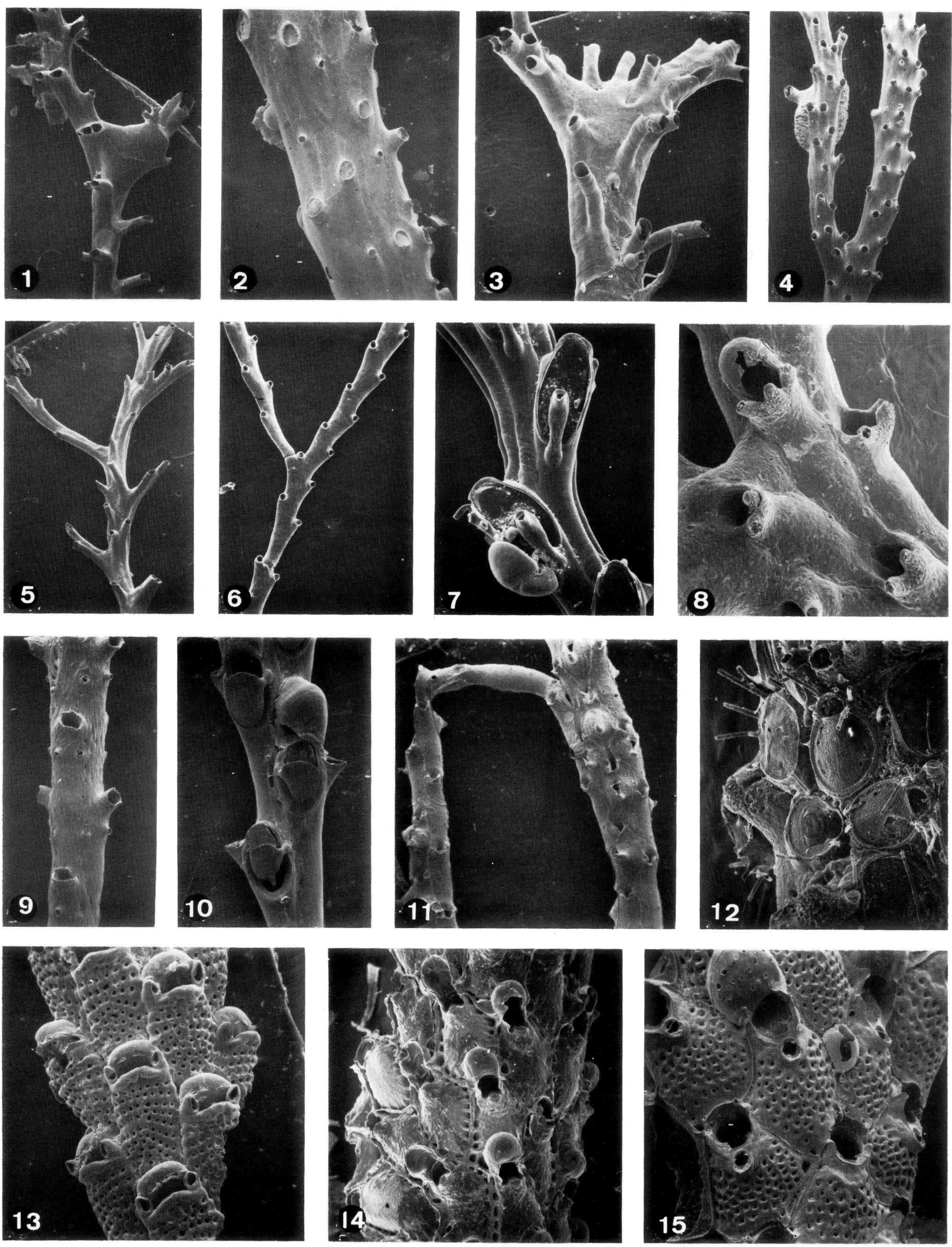
S Fig. 13. Bathymetry and facies

21891-1B

Deep Slope Facies

distribution along OFOS-track 21891-1B, middle southern slope. Legend see Fig. 6.

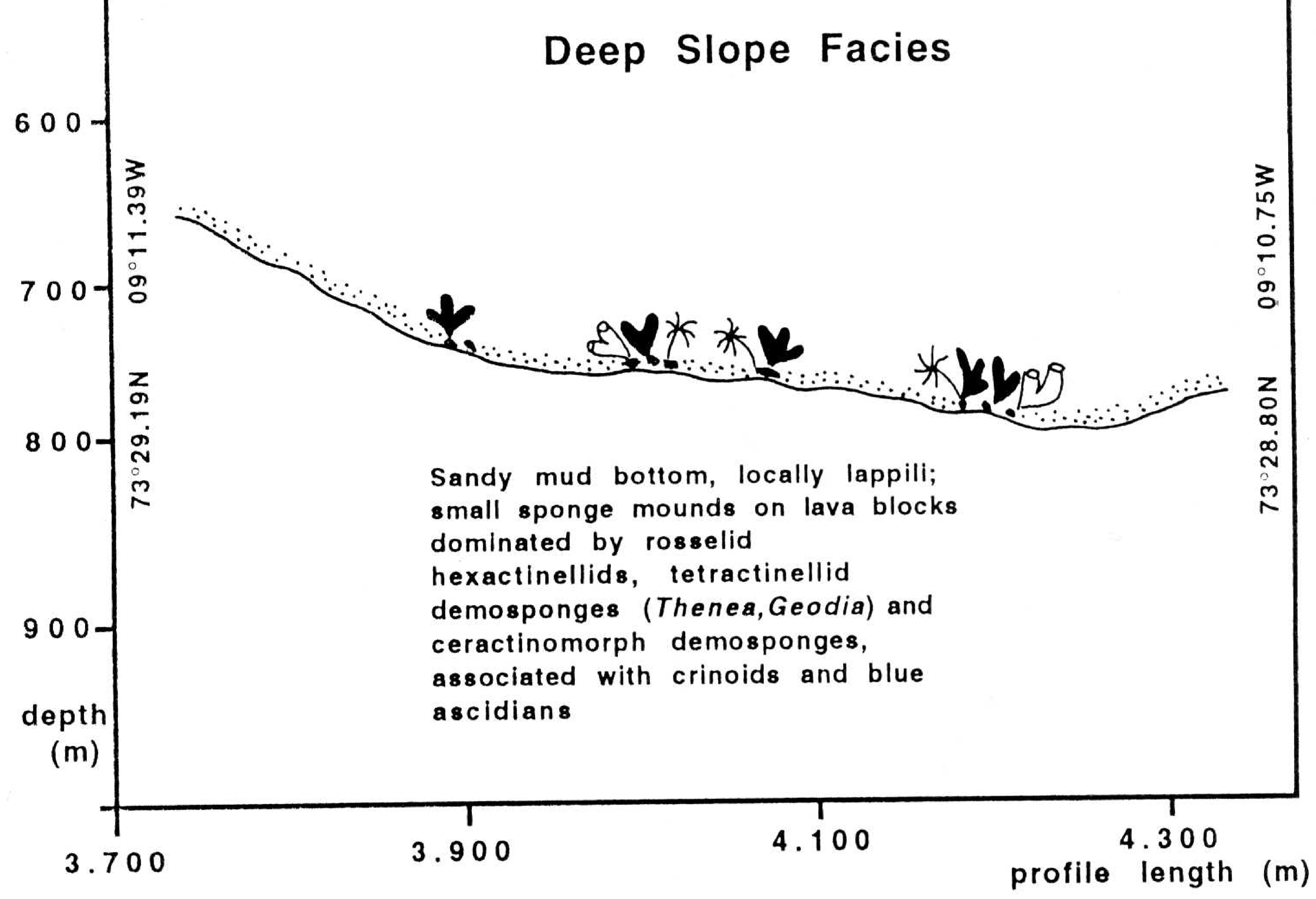

The bryozoans are associated with thin and transparent blue ascidians (Pl. 20/3). This deep water ascidian appears first at about $-650 \mathrm{~m}$ but is relatively common throughout the entire deep slope facies. The associated sponge fauna is rather

scarce and small-sized. However, bushes of Clathria and a few small geodiids as well as residual bodies of the lyssacine hexactinellid Schaudinnia are present. Small actinians are relatively common.

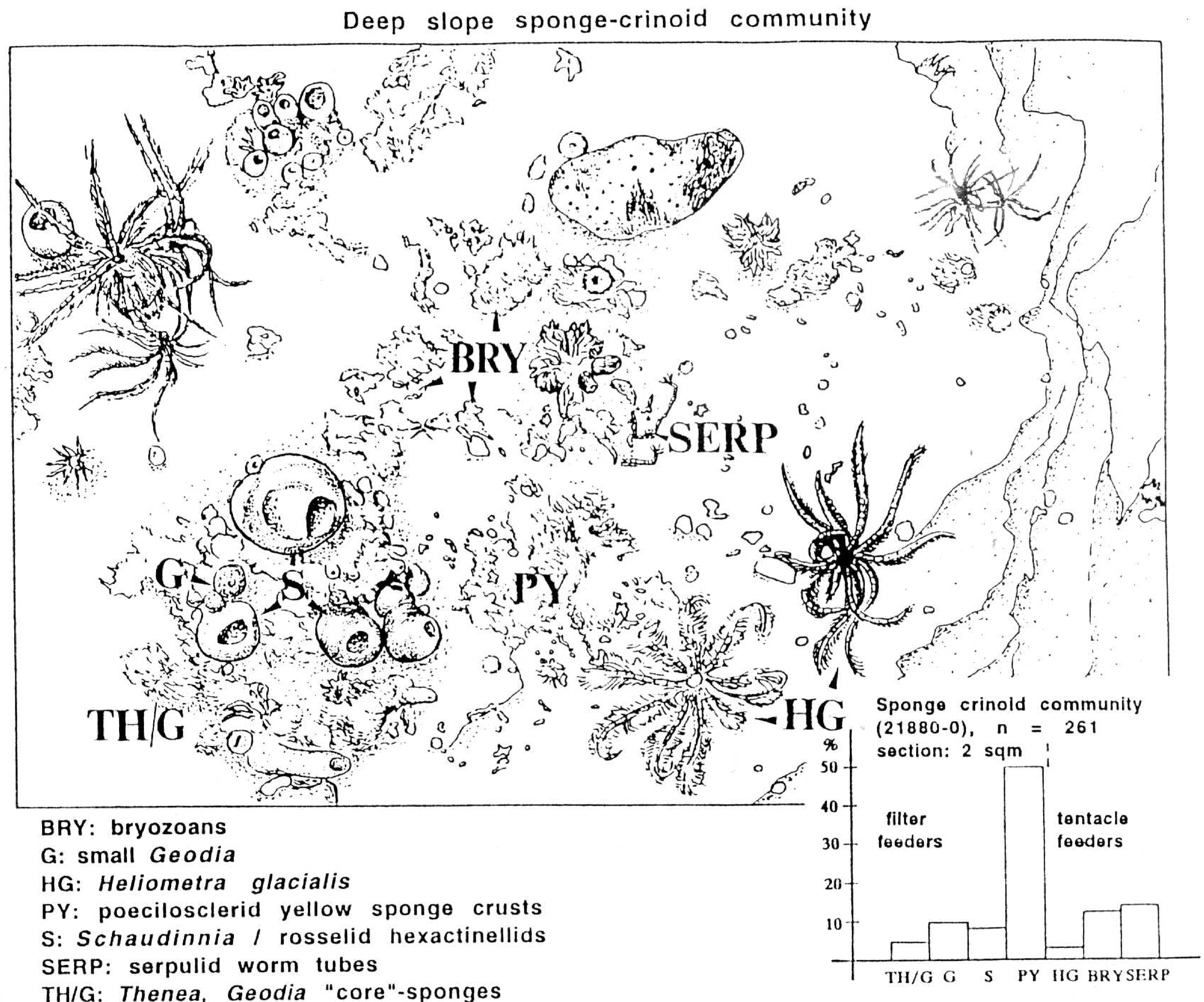

Fig. 14. Deep slope sponge crinoid community with statistical analysis of functional feeding groups for a representative sector in the deep slope facies (see Pl. 20/4). 


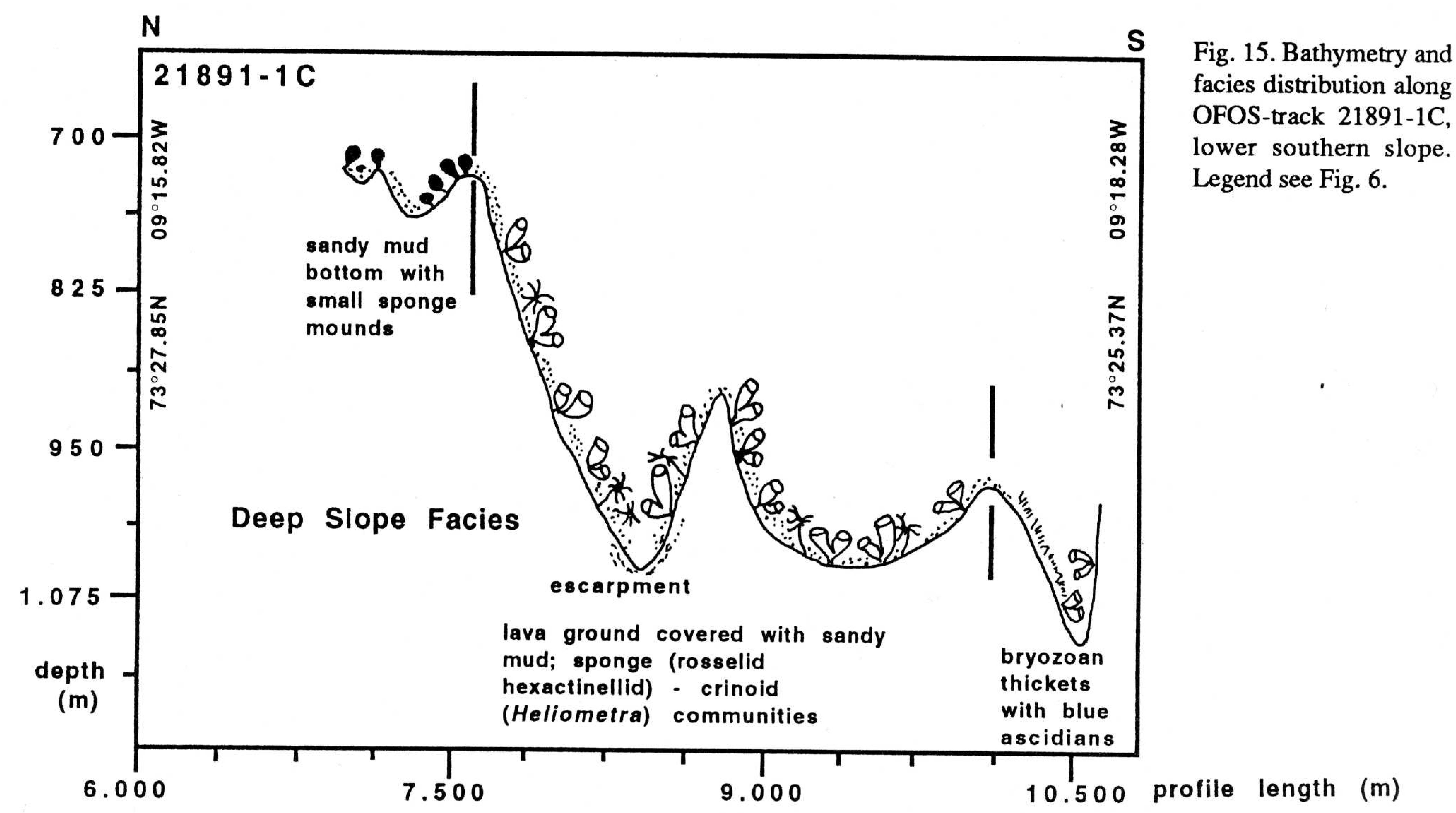

\section{Small deep slope sponge mounds and volcanoclastic deposits $(-1.532 m$ to $-2.063 m)$}

On the lower flanks of the seamount numerous small side-cones have been identified by hydrosweep mapping. This deeper zone displays a completely different biozonation than that in the shallower areas of the deep slope facies. The morphology of the lower part of the northeastern flank undulates. In the OFOS survey $21883-0$ between $-1.650 \mathrm{~m}$ and $-2.000 \mathrm{~m}$, there may be an older sediment-buried crater. The seafloor between $-1.600 \mathrm{~m}$ and $-1.650 \mathrm{~m}$ is covered with muds or sandy muds with abundant vertical worm tubes. Occasionally bottom current winnowing has formed carbonate-rich foraminiferal lag-deposits. Locally, volcanoclastic mass flows with coarse sharp-edged lava blocks and oxidized lava fragments and lapilli dissect the area.

On small elevations, the volcanic foundation crops out with a rough lava block or pillow surface. Within these areas small mound-shaped sponge buildups and hardrock-related sponge communities have developed (Fig. 16). These sponge buildups display a clear bathymetric zonation with a narrow ranged assemblage, the Hyalonema-Rosselidae-CladorhizaThenea community at $-1.600 \mathrm{~m}$ to $-1.655 \mathrm{~m}$, and a more broadly ranging Caulophacus-Hyalonema-Cladorhiza community at $-1.655 \mathrm{~m}$ to $-2.063 \mathrm{~m}$.

\section{a. Hyalonema-Rosselidae-Cladorhiza-Thenea community}

Small specimens grow on larger volcanic clasts of the black sediments in channels and debris flows. The sponge community is characterized by wine glass-shaped amphidiscophorid hexactinellids of Hyalonema (Fig. 17, Pl. 21/14). This taxon is charaterized by bundels of large root spicules and is therefore easy recognizable in underwater

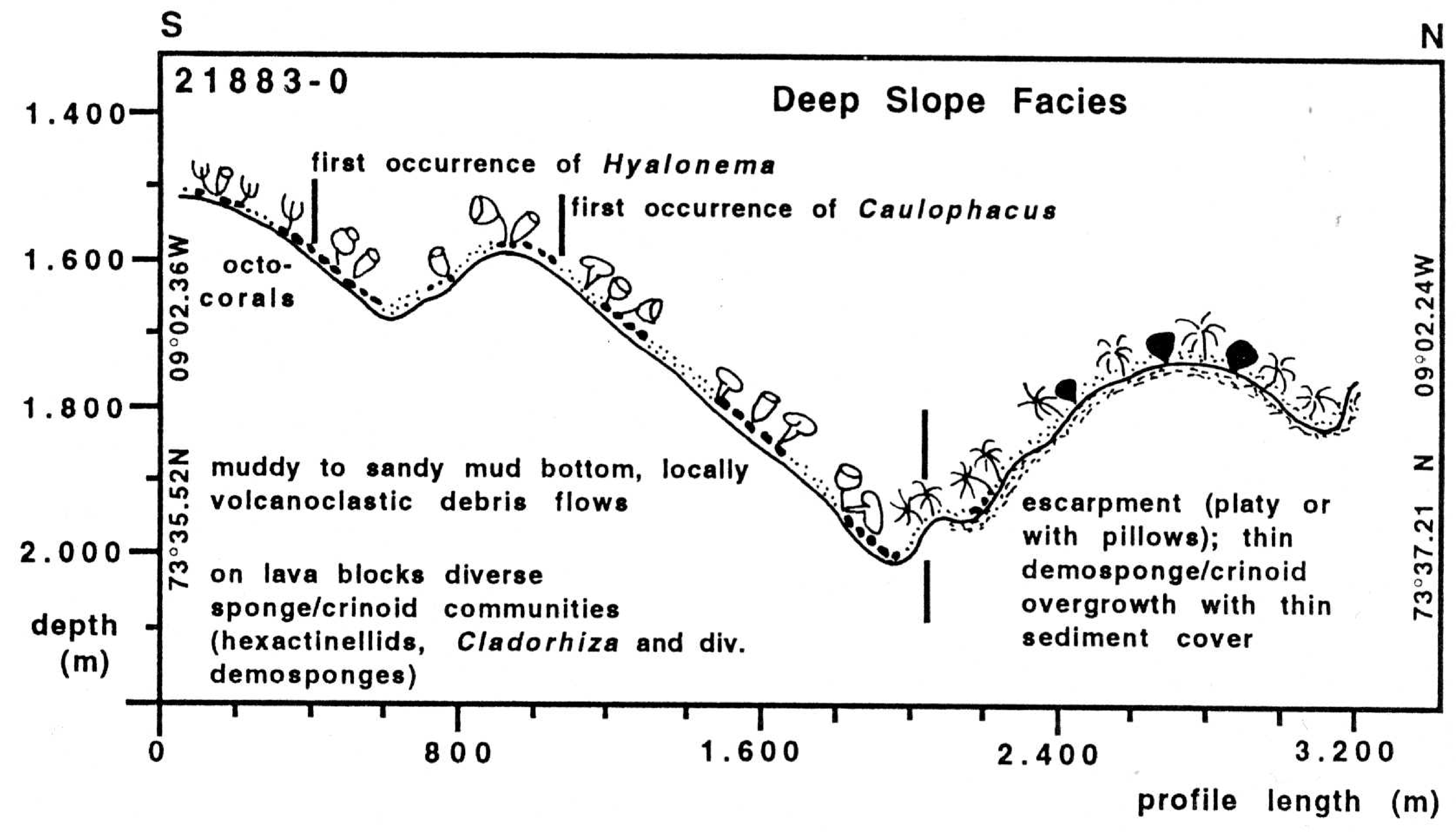

$\mathrm{N}$

Fig. 16. Bathymetry and facies distribution along OFOS-track 21883-0, distal northern slope. Legend see Fig. 6. 


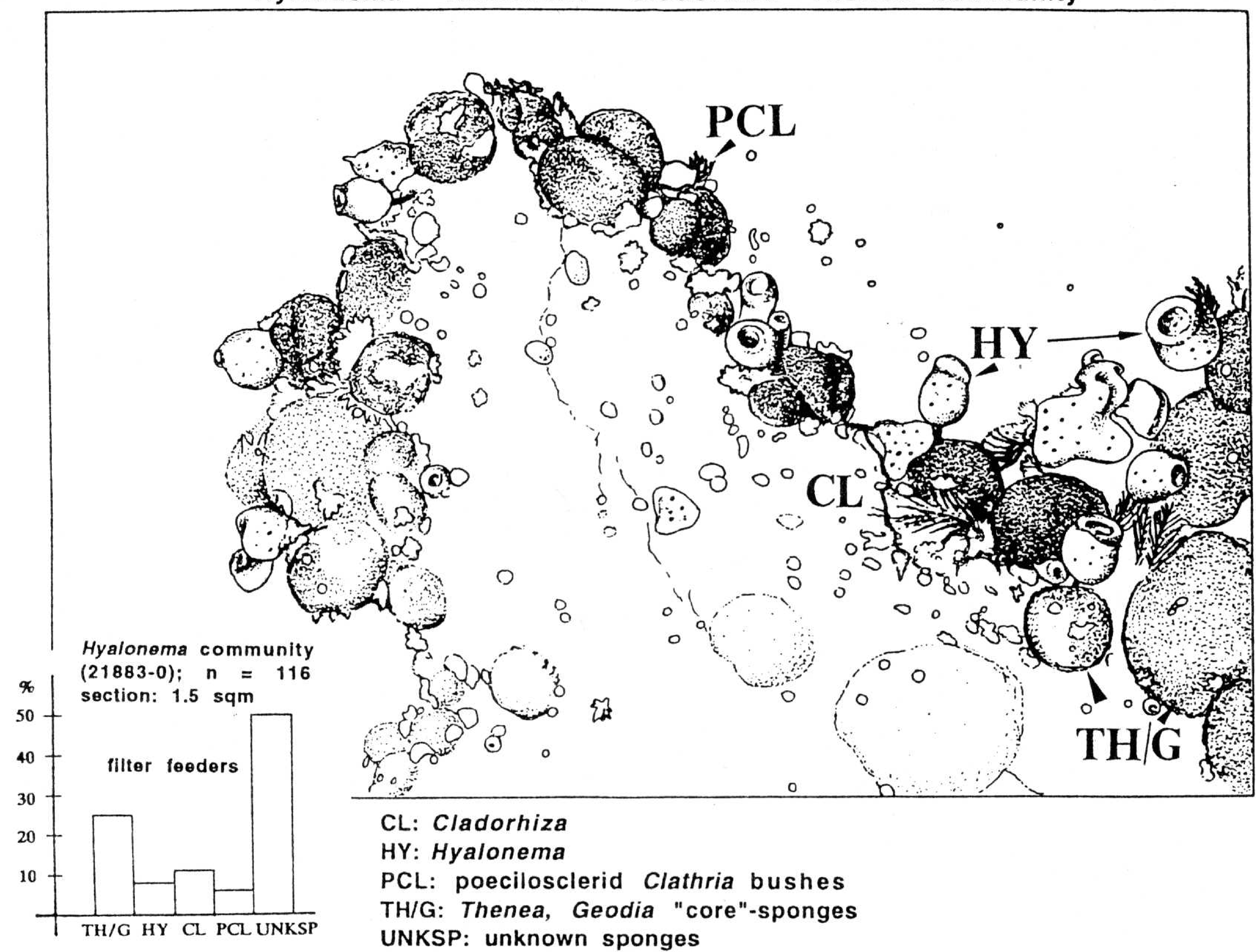

Fig. 17. Hyalonema-Rosselid-Cladorhiza-Thenea community with statistical analysis of functional feeding groups for a representative sector in the deep slope facies (see Pl. 21/2).

photographs. Another new sponge element is the strange poecilosclerid Cladorhiza, which grows as small tree-like sponges (Pl. 21/1-4). The first sponge generation on this hard substrate is represented by large ball-shaped Thenea $\mathrm{sp}$. and probably Geodia sp. All of these core sponges exhibit a dark grey colour resulting from fine sediment which is fixed between the protruding large dermal spicules. Some of them exhibit white areas indicating active growth. Rossellid hexactinellids are commonly represented by the taxa Schaudinnia and Scyphidium quite often combined with grey coloured residual skeletons. Some irregularly shaped big white sponges are observed, which demonstrate affinities to the rigid hexactinose hexactinellid Chonelasma.

The poecilosclerid Clathria bushes are minor elements of the sponge community. On hardrocks, many unidentified small white sponges are present which may be young hexactinellids. On some pillow surfaces blue grey coloured crusts are visible which may be sponges, too, perhaps taxa of poecilosclerids (e.g. Hymedesmia). Large volcanic bocks were sampled with a TV grab from $-1.660 \mathrm{~m}$ to $-1.668 \mathrm{~m}$ (GIK 21885-3). These lava bocks had been colonized by living ascidians, serpulids, Hyalonema, and bryozoans with solid arborescent colony growth forms and sizes typical of Hornera lichenoides. Loose sediment is composed of bryozoan fragments which are heavily corroded and iron/ manganese-stained, indicating a long time of exposure at the sediment surface. The bryozoan fauna includes Palmicellaria skenei and Sertella elongata as the most abundant species, followed in importance by Hornera lichenoides, Diplosolen intricarius, Tessaradoma gracile,Idmidronea atlantica var. gracillima, Porella compressa, Porella plana, Cribrilina watersi,Smittina glaciata, and Schizoporella porifera. Crisia sp., Tubulipora sp., and Tricellaria gracilis are considered to have been alive most recently.

\section{b. Caulophacus-Hyalonema-Cladorhiza community}

The deepest investigated area of the marginal cone mound between $-1.800 \mathrm{~m}$ to $-2.063 \mathrm{~m}$ is characterized by the lyssacine hexactinellid taxon Caulophacidae (Caulophacus arcticus). Caulophacus arcticus is a typical deep water hexactinellid with a depth range from $-1.450 \mathrm{~m}$ to $-4.379 \mathrm{~m}$ (Koltun 1967). The specimens observed exhibit characteristic mushroom shapes and are relatively large (more than $20 \mathrm{~cm}$ high) (Fig. 18, Pl. 21/4). They commonly grow on large ball-shaped sponges (Thenea). The long funnel shafts are dark grey at their bases, and this feature resembles the residual structures seen in various taxa of the Rosselidae (Schaudinnia). The remaining sponge fauna is identical to those of the Hyalonema-Rosselidae-Cladorhiza-Thenea community. The vagile crinoid Heliometra glacialis is common and fixes its root arms on large hexactinellid sponges or within fissures of lava blocks.

\section{Deep slope soft bottom Bathycrinus communities ( $-1.532 \mathrm{~m}$ to $-1.600 \mathrm{~m})$}

Muddy soft bottoms containing sparse small rock fragments which have a low abundance fixosessile benthos (21883-0-83) are typical from wide areas on the deeper northeastern flank of the Vesterisbanken. Characteristic for 
Deep slope Caulophacus community

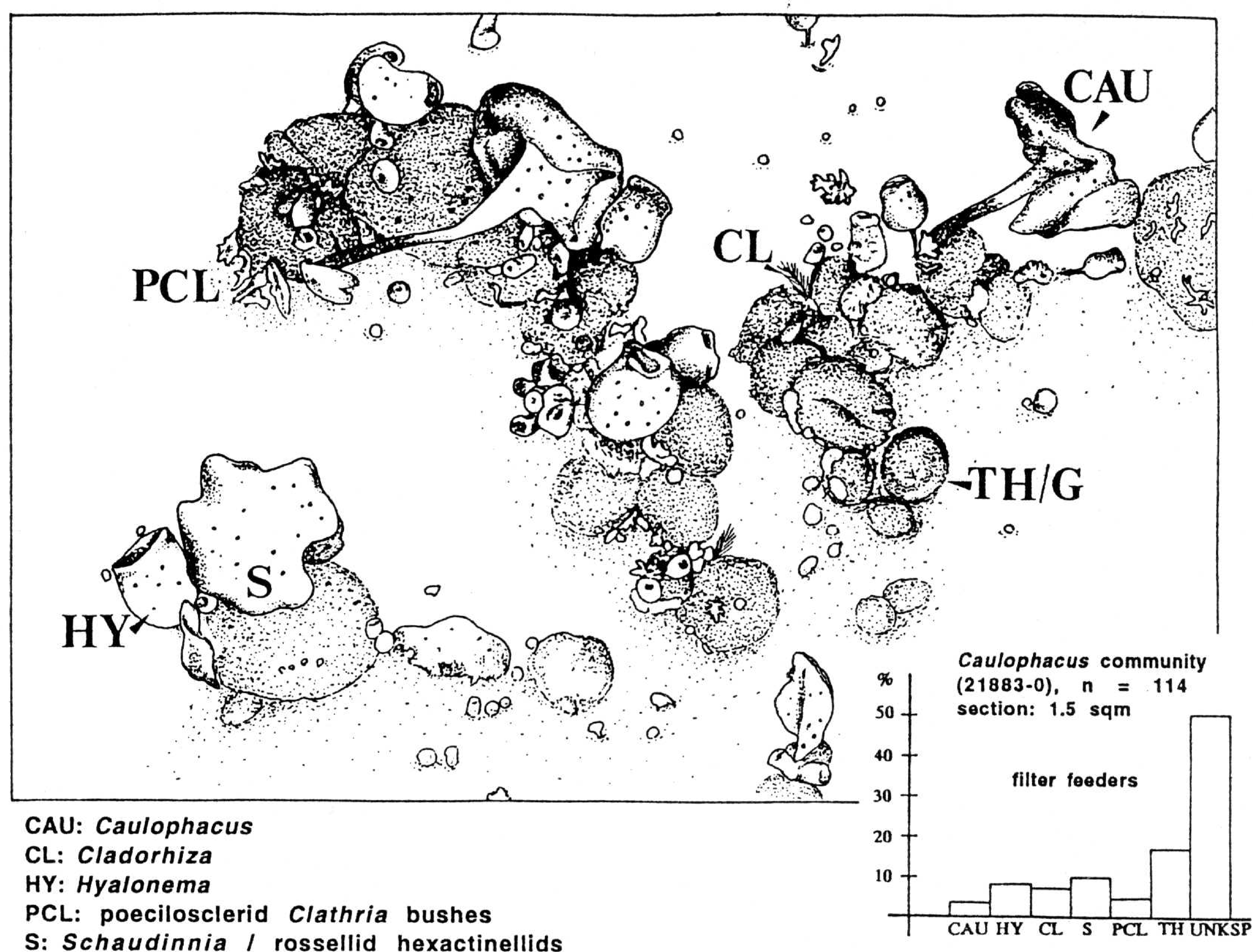

S: Schaudinnia / rossellid hexactinellids

TH/G: Thenea, Geodia "core"-sponges

UNKSP: unknown sponges

Fig. 18. Caulophacus community with statistical analysis of functional feeding groups for a representative sector in the deep slope facies (compare to Pl. 21/4).

this facies are sessile crinoids (Bathycrinus carpenteri). This typical deep water crinoid is closely associated with octocorals and actinians.

\subsubsection{The Abyssal plain facies}

The abyssal plain surrounding of the Vesterisbanken Seamount is characterized by fine-grained sediments found in 3 deep water box corer samples (GIK 21878-2, 21882-1, and 21892-1). Abundant benthic foraminifera (Pyrgo and several $\mathrm{mm}$-sized agglutinated species) occur on the sediment surface. On these small "islands", small sponges of the Calcarea are attached, mainly Grantia and Leucosolenia. Characteristic for this zone is the small tetractinellid Thenea abyssorum which is adapted to muddy sediments. Thenea abyssorum exhibits umbrella-like large dermal spicules which prevent the sponge from sinking into the soft bottom. This type of sponge is relatively common, a mean of 20-30 specimens were collected on the surface of each giant box core (area: $0.5 \mathrm{~m}^{2}$ ).

\subsection{Indications for hydrothermal activity}

Indications for recent hydrothermal activities are scarce. In profile 21878-1 (Fig. 3) a slight elevation of temperature (by 0.1 to $0.15^{\circ} \mathrm{C}$ ) may be recognized between -740 to -840 $\mathrm{m}$. It seems, however, improbable that this represents an indication of a hydrothermal "plume", as it would require a strong vent of sufficiently high temperature to create this anomaly in a 100-m-thick water mass more than $10 \mathrm{~km}$ remote from a possible vent. Nevertheless, a slightly increased signal for Mn was found just at this depth, while $\mathrm{Fe}$ and methane are nearly unchanged compared to deeper and higher sections of the water column. If these slightly elevated temperature and $\mathrm{Mn}$ values were real indications for present hydrothermalism, active vents could probably be expected at water depths near $1.000 \mathrm{~m}$ on the southern flanks of the seamount. No samples and CTD-profiles, however, are available from deeper flank sites to substantiate this vague suspicion.

Visual indications of active hydrothermalism were not able to be detected from the black \& white TV-recordings. From the color slides, however, yellow to orange coloured hues on the sediment surface were found along profile $21880-0$ at $-150 \mathrm{~m}$ to $-170 \mathrm{~m}(\mathrm{Pl} .18 / 2)$. These coloured spots extended no more than about $1 \mathrm{~m}^{2}$. No discharge openings or "smoker" edifices could be detected. The fresh hues and the lack of biogenic colonization, however, suggest that weak hydrothermal discharge is still active at these sites. These still active points probably mean that the northeastern part of the crest area was one of the last sites of volcanic activity on the Vesterisbanken. At 2 TV-grab sites (218853 and 21891-4) yellowish to reddish brown oxide crusts and stained scoriaceous material was found. Oxide encrusted organisms found in TV-grab sample 21885-3 indicate that 
weak hydrothermal emanations were still active recently at this site. Similar oxide crusts were dredged in 1984 on the southeastern slope. These observations document recent hydrothermal activities at widely distributed areas of the seamount edifice.

\section{DISCUSSION \\ 4.1 Sediment dynamics}

The specific oceanographic conditions and the faroffshore position of the Vesterisbanken Seamount are important controlling parameters which define the major processes of sediment dynamics on the seamount. The nearly year round sea-ice cover and its short-term retreat (mostly during August and September) results in episodic peak sediment and nutient supply from surface waters. Ice edge blooms of phyto- and zooplankton organisms and melting of sea-ice deliver large quantities of particulate and suspended organic matter into the surface waters. In addition, fine-grained terrigenous sediments may be released from melting ice fols. Along the ice edge, the zooplankton, specifically the planktic foraminifer Neogloboquadrina pachyderma (sinistral) develops a high standing stock during the ice-free season. Their calcareous tests are subsequently delivered as pelagic carbonate rain to the seafloor. As a result, organic matter, pelagic carbonate tests and terrigenous fine-grained particles show strong seasonal short-term sedimentation peaks, which arrive at the seafloor within a period of less than two months.

Other observations of importance are frequent indications of bottom current activities at almost all depth levels of the seamount. These currents probably derive from a streamlined downwelling anticyclonic vortex known as the $T_{A Y L O R}$ column. As a result there is a rapid transfer of organic matter, planktic tests and terrigenous particles to the bottom. Within a TAYLOR column, the strongest bottom currents are expected over the top of the seamount. Such a configuration seems to be realized over the Vesterisbanken. This is indicated by the wide coverage of biogenic structures formed by filter-feeding organisms, mainly bryozoans and sponges, and serpulids. In addition, the overall construction of the widespread biogenic mat has characteristics which resemble lag-deposits (ironstained byrozoan or serpulid skeletons). The overall impression is that the top of the seamount is continously current swept and most fine-grained particles are transported downslope. Filter-feeding organisms preferentially colonize small elevations, where they reach above the near bottom laminar current regime (ALTENBACH et al. 1987, LUTZE \& AltENBACH 1987). As a result, all biogenic structures are initiated either on elevations of the volcanic foundation or on the crests of ripple fields. The close relationship between morphostructures of biogenic buildups and relief in the foundation indicates that local relief probably determines changes in bottom current parameters, which, in turn, exaggerate a primary control in the shaping of biogenic structures. In particular, morphostructures such as hedges or spurs as well as flatcake mounds substantially support these assumptions.
Two major sedimentological processes operate on the flanks of the seamount, e.g. downslope sediment transport and deposition of fine-grained suspended particles in lee position. As a consequence, there is a downslope increase in overall sediment thickness and a general decrease in grainsize. Sea-floor characteristics change downslope in a predictable way. On the upper slopes, semi-stabilized sand or sandy mud bottoms dominate, while the deeper slopes are characterized by soft mud bottoms intersected by volcanoclastic flows (Pls. 21/1, 22/1). Again, all hard rock substrates are rapidly colonized by filter-feeding communities.

Apart from more or less continous sedimentological processes, the seamount has been variously influenced by episodic volcanic events. In particular, a pyroclastic layer in the Holocene sediment cover of the seamount close to surface (see shallow slope facies) indicates a young volcanic event on the Vesterisbanken Seamount. The rapid colonisation of the pyroclastic substrate is important. It corresponds with similar observations of a rapid colonisation on young, shallow water lava surfaces at Jan Mayen (GULLIKSEN et al. 1980). The patchy distribution of buildups may also point in this direction. That such volcanic events do not represent a single case during the younger history of the Vesterisbanken Seamount is evidenced by coring on the surrounding abyssal plain (GIK 21878-3, 21882-2, and 21892-3). Up to 17 discrete sandy/silty ash layers are present within 6 to 8-m-long sediment cores (WALLRABE-ADAMS in THIEDE \& Hempel 1991). The uppermost 8 to $17-\mathrm{cm}$-thick ash layers are covered by 15 to $110 \mathrm{~cm}$ homogeneous brown pelagic silty clay. Considering the low sedimentation rates of the area, we estimate that this last major eruption took place near the Pleistocene/Holocene boundary. These observations show that until modern times shorter periods of volcanic activity are separated by longer time intervals of inactivity. The Vesterisbanken Seamount is at present a dormant volcano.

\subsection{Formation of spiculites: actuopaleontological results from Arctic sponge communities}

The dense organic meshwork coverage of the seamount down to $-260 \mathrm{~m}$ is unique and has not been described from the Arctic realm. Bullivant \& DEARBoRn (1967) sampled a similar spiculite-bryozoan meshwork with Limatula bivalves from volcanic grounds of the Antarctic McMurdo Sound. The stable spicule meshwork is interpreted as an autochthonous spiculite. This type of organic-rich sediment is also present on a ridge northwest of Jan Mayen (P1. 23/12) and is also described by VAN WAGONER et al. (1989) as occurring in shallow water of the northern Canadian Arctic Islands. The spicule networks are responsible for the dense cover with fixosessile benthos, because the open pore space of the spicule network and microbial cover of the spicules are an ideal biogenic substrate for settlement of larvae (Pl. 23/3-6). The great stability of this sediment type on the steep slope of the Vesterisbanken Seamount results from an interaction of spicule networks and the settlement of fixosessile benthic organisms. The spicule mats are a result 
of relatively long-term stable ecological conditons, perhaps the entire Holocene, following re-establishment of normal marine conditions after glaciation or after the last volcanic eruption near the Pleistocene/Holocene boundary. Most of the sponges are long-lived k-strategists (e.g."core" sponges, lyssacine hexactinellids), are adapted to oligotrophic stable conditions and survive in Arctic cold waters. They form residual bodies in winter. These condensed skeletons may be reactivated at the beginning of the Arctic summer coincident with increasing food supply from the surface waters. Most observed sponges exhibit numerous small, mostly asexual, buds (Thenea and hexactinellids) which are probably also linked with increasing food supply.

\subsection{Bryozoan ecology}

\subsubsection{Species composition}

Bryozoan samples cover all facies belts at Vesterisbanken Seamount. The sampled material revealed at least 21 taxa (Tab. 4, Pl. 24/1-15).

Most bryozoan taxa found at Vesterisbanken Seamount are Arctic-boreal, Arctic-circumpolar or high Arctic species (KLUGE 1975). Despite the high geographic latitude of the seamount and its position within the Arctic water masses of the EGC, some species occur that are also known from the non-Arctic North Atlantic. This seems to be the case, especially for Hornera lichenoides, for which a cosmopolitan occurrence is presumed.

\subsubsection{Depth zonation, growth forms and adaptation to seasonal food supply}

Identification of bryozoan taxa on the many photographs is based on colony growth form and on comparison with a limited number of samples taken from similar bathymetric settings. Our understanding of the depth-related occurrence of bryozoans remains therefore tentative.
Although most bryozoan species show a wide bathymetric range at Vesterisbanken Seamount, the facies belts seem to be dominated by distinct bryozoan taxa that produce specific biogenic structures (Fig. 19).

Of striking significance is the volumetric dominance of taxa with erect growth forms among the Cheilostomata and Cyclostomata in contrast to the eastern shelves of the Norwegian-Greenland Sea, where encrusting taxa prevail at all water depths. At Vesterisbanken, erect-growing taxa with arborescent colony growth forms are Hornera lichenoides, Palmicellaria skenei, Porella plana, Porella compressa, Leieschara subgracilis, Tessaradoma gracile, and Idmidronea atlantica var. gracillima. Species with reticulate growth forms are Sertella elongata, Sertella beaniana, and Diplosolen intricarius occur. In addition, species such as Notoplites normanni, Tricellaria gracilis and Crisia sp. grow as weakly calcified, articulate colonies. Less frequently than the erect-growing taxa, several species with encrusting zoarial growth forms such as Cribrilina watersi, Schizoporella porifera, Smittina glaciata, ? Megapora rigens, Schizoporella thomsoni, and Disporella sp. occur as epibionts on other bryozoan colonies, serpulid tubes and mollusc fragments.

Colonial growth forms of bryozoans have been related to different environmental settings and are frequently used for interpretations of water energy regimes (STACH 1936, SCHOPF 1969, HaRmelin 1975, Nelson et al. 1988). Based on the volumetric dominance of bryozoan species that either possess weakly calcified, articulate colonies, or erect and nonarticulate, but sometimes fenestrate, colonies, a medium current velocity above the sea floor is interpreted to occur at nearly all water depths at Vesterisbanken Seamount.

Thus, weakly calcified, but articulated colonies of $\mathrm{No}$ toplites normanni and Tricellaria gracilis together with hydrozoans, sponges and serpulids form the living cover of the sponge-bryozoan mats that occur at the crest of the

Cribrilina watersi ANDERSSON
Crisia sp.
Diplosolen intricarius (SMITT)
Disporella sp.
Hornera lichenoides (LINNE)
Idmidronea atlantica var. gracillima (BUSK)
Notoplites normanni (NORDGAARD)
Leieschara subgracilis (D'ORBIGNY)
Palmicellaria skenei (ELLIS \& SOLANDER)
Porella plana HINCKS
Porella compressa (SOWERBY)
Pseudoflustra sinuOSa (ANDERSSON)
Schizoporella porifera (SMITT)
Schizoporella thomsOni KLUGE
Sertella beaniana (KING)
Sertella elongata (SMITT)
Smittina glaciata (WATERS)
Stegohornera arctica (KLUGE)
Tessaradoma gracile (SARS)
Tricellaria gracilis (VAN BENEDEN)
Tubulipora cf. T. ventricosa BUSK

Cribrilina watersi ANDERSSON

Crisia sp.

Diplosolen intricarius (SMITT)

Idmidronea atlantica var. gracillima (Busk)

AARD)

Palmicellaria skenei (ElLIS \& SOLANDER)

Porella compressa (SowERBY)

Pseudoflustra sinuosa (ANDERSSON)

Schizoporella porifera (SMITT)

Schizoporella thomsoni KLUGE

Sertella beaniana (KING)

Sertella elongata (SMITT)

Smittina glaciata (WATERS)

Stegohornera arctica (KLUGE)

Tricellaria gracilis (VAN BENEDEN) arctic-atlantic

arctic

arctic-boreal, atlantic

boreal-atlantic; deepwater

high arctic; deepwater

arctic, circumpolar

arctic-boreal, atlantic

arctic-atlantic

arctic-boreal, circumpolar

high arctic; deepwater

arctic

arctic

arctic-boreal, atlantic

arctic, circumpolar

high arctic

boreal-atlantic; deepwater

arctic-boreal, atlantic; deepwater

arctic, circumpolar

arctic, circumpolar
Tab. 4. List of bryozoa identified from the Vesterisbanken Seamount. 


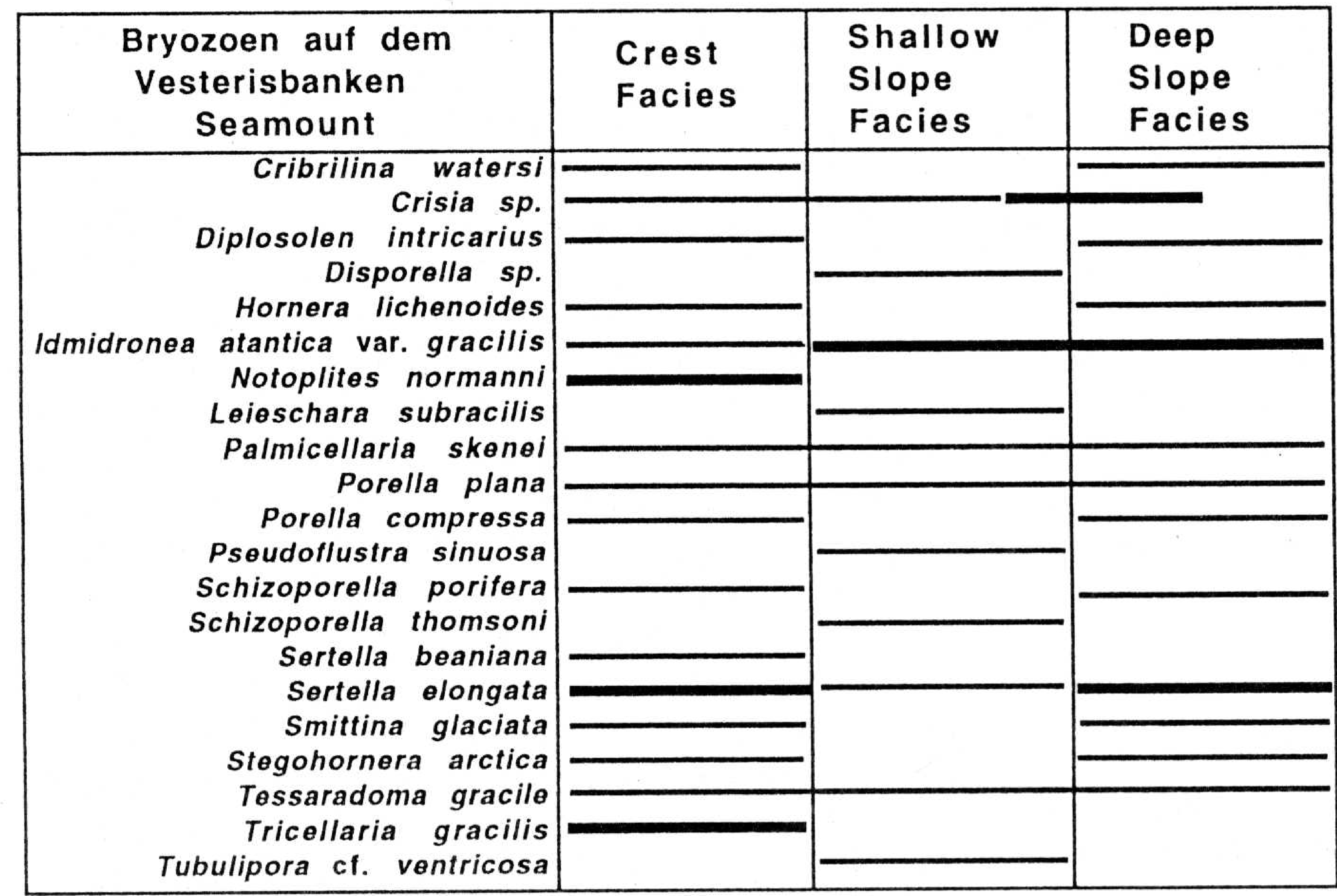

Fig. 19. Occurrence of bryozoan taxa in the 3 facies belts at Vesterisbanken Seamount (thin lines). Formations of prominent bryozoan aggregations are indicated with thick lines. seamount. The bryozoan-hydrozoan thickets form protected biotopes with more reduced water energies that are also occupied by a number of species with erect, but more fragile growth forms, such as Sertella elongata, Idmidronea atlantica, Tubulipora div. sp., species such as Palmicellaria skenei with stout, erect colonies, or encrusting species such as Cribrilina watersi, Schizoporella porifera, Smittina glaciata, and ?Megapora rigens.

Stout colony fragments of Palmicellaria skenei are the most significant bryozoan constituents that contribute to the formation of carbonate sediment at all water depths. The sediment contains mainly dead and heavily corroded colony fragments of Palmicellaria skenei and otherbryozoan species stained by iron/manganese, indicating a period of nondeposition or erosion on the sea floor caused by bottom currents.

The physiography of the seamount, the limited terrigenous input and the transport of seasonally produced nutrients by TAYLOR current downwelling, enables the bryozoans to occur down to great water depth with high diversities and population densities. Competition for food seems to be the major factor causing the predominantly erect colony growth forms of bryozoan taxa. This has been assumed also for the benthic communities living on small dropstones in high latitude pelagic soft substrate environments such as the Vøring Plateau in the Norwegian Greenland Sea (OschmanN 1990). In contrast, competition for space among bryozoan species is distinctly limited due to the preferred upward growth of the colonies that support the formation of numerous distinct bryozoan communities.

Due to the highly seasonal production of organic matter in the subsurface water masses, variations in nutrient supply may cause various seasonal growth patterns in organisms at Vesterisbanken Seamount. An intense benthic/pelagic coupling as demonstrated by GrAF (1989) for deep-sea benthic communities on the Vøring Plateau in the Norwegian Sea is also assumed to occur in benthic communities at Vesterisbanken. In bryozoans, reproductive cycles stimulating the formation of brood chambers (cyclostomes) or ovicells (cheilostomes), as well as rhythmic growth banding that occurs in the extra-zooidal skeleton in species such as Hornera lichenoides, may be related to such seasonal nutrient cycles. Most sectioned colonies of several species were found to be empty or to display degenerated polypides and soft tissues. Most colonies of Horneralichenoides, especially, young polypides were found to have grown on top of several degenerated bodies within their zooecia. Such degeneration/ regeneration cycles in Arctic bryozoan species might be an adaptation to survive the Arctic winter.

Bryozoans are known to feed on a variety of nutrients depending on their specific feeding behavior, the polypide and tentacle dimensions as well as the morphofunctional specializations of the digestive tract (WINSTON 1981). Thus, degenerated polypids in colonies of Diplosolen intricarius investigated in thin sections more frequently contain complete tests of planktic foraminifers, whereas Hornera lichenoides may have a diet consisting only of diatoms. Furthermore, the strength and flow pattern of the actively produced feeding currents on colony surfaces is considered to be largely controlled by the zooecial budding pattern that causes the arrangement of zooecial apertures on colony surfaces (TAYLOR 1979, WinsTON 1981).

\subsubsection{The vagile epibenthos}

The vagile epibenthos is present in every facies belt of the Vesterisbanken Seamount. In general, abundance and diversity of the vagile organisms decreases downslope. The most obvious epibenthic group are echinoderms, with starfish (Henricia, Solaster, Hymenaster), brittle stars (Ophiopleura and more unidentified genera), and sea feathers (Heliometra glacialis). The latter is more abundant in the deep slope facies, whereas sea stars and brittle stars are present in the crest facies and shallow slope facies. No sea urchins or sea cucumbers are visible in the photos.

Molluscs are the second major vagile epibenthic group. The bivalves are represented by pectinids (Cyclopecten imbrifer, Cyclopecten graui) and limiids (Limatula hyperborea). They inhabite the crest facies and are major 
elements of the shallow slope facies without being fixed by a byssus to the substrate. It should be stressed that these bivalves are able to float. Gastropods are rare and are representated by carnivore buccinid and naticid forms. The latter predates bivalves as is evidenced by numerous drilled holes in the valves. The semi-stabilized sandy muds of the shallow slope facies are occupied by onuphid polychaetes, building quivers of broken pectinid bivalve shells, suggesting a predator-prey relationship between them.

In summary, all identified members of the vagile epibenthos are also elements at many other Subarctic and Arctic localities (OCKelmanN 1958, RASMUSSEN 1965, BERNHARD 1979, LuBinsky 1980, PiepenBuRg 1988, OschmanN 1991).

\subsection{Arctic mixed siliceous and carbonaceous deposits: modern end members of the Foramol facies?}

Cold water siliceous and carbonaceous deposits formed by sponge-bryozoan constructions are regarded as low accumulating end members of the Foramol facies. This term is widely used for non-tropical carbonate deposits formed by foraminifers, molluscs, balanids, echinoderms, bryozoans, and coralline algae (LEEs \& BULLER 1972). Modern cold water, siliceous carbonate deposits are formed under completely different environmental settings than their tropical counterparts. A good knowledge of principle controlling parameters in their formation will provide us with a different set of interpretations. Critically considered, they may serve as a non-tropical alternative for models of similarly composed low diverse and low accumulating carbonate deposits in the fossil record.

Physical parameters of the mixed biogenic siliceous and carbonaceous sediments on the Vesterisbanken Seamount represent the cold end member of modern carbonate deposition. Very low temperatures close to $0^{\circ} \mathrm{C}$ and salinities around $34.5 \mathrm{ppt}$ are recorded at nearly constant values over the entire water column, and thus seem to have no influence on the pronounced depth-related biogenic zonation on the seamount. All biogenic constructions are formed in aphotic depths.

Apart from the seasonal pulse of fine-grained sediments released from melting sea ice, the paucity of terrigenous sediment input favors concentration of biogenic skeletons on the seafloor. Due to harsh, nearly year-round pack ice covered Arctic conditions over the seamount, the food supply reveals a strong seasonality. The transfer of food to the seafloor communities is specifically effective due to an oceanographic configuration found over seamount obstacles - the TaYLOR column. An almost stable stratified water column in combination with current regime disturbances generated by seamount obstacles cause oceanographic complexities that strongly influence biological processes in the water column as well as standing stocks and diversity of the benthic fauna (BOEHLERT 1987). One possible result is the TAYLOR column (TAYLOR 1923), a closed stream-lined anticyclonic vortex that is trapped above isolated seamounts (HOGG 1973, HUPPERT 1975). Trapping of nutrients in shallow waters of the upper TAYLOR column may enhance primary productivity. Such enhanced productivity or advection and concentration of food produced elsewhere may explain the high standing stock of benthic seamount communities, especially of filter-feeding organisms.

The depth-related zonation of ecosystems may correspond to variations in quality and quantity of downslope food transfer as well as increasing hydrostatic pressure. Prevalent nutrient sources depending on water depth. The distribution and concentration of phyto- and zooplankton vs. particular organic matter may, in addition, control the depth-dependent zonation and composition of the benthic seamount communities. Furthermore, bacterial symbiosis and/or the take up of dissolved organic matter might support nutrition in sponges and enhance stabilization of spiculite frameworks.

We can only speculate about the fossilisation potential of the Arctic sponge-bryozoan-serpulid mounds and biogenic mats studied on the Vesterisbanken. At the low accumulation rates observed we would expect a considerable loss of biogenic silica during diagenesis. The resultant sediment after diagenesis could be a siliceous limestone-bearing abundant cool-adapted pelagic and benthic organism. Partial preservation of the in situ framework of sponge spicules within early chert nodules may refer to the process of in situ spiculite formation that is characteristic for the studied siliceous mats from the seamount.

In summary, the different sponge-bryozoan-serpulidechinoderm biogenic structures of the Arctic Vesterisbanken Seamount provide us with an example of one potential end member of the ForAMOL facies, in which the primary control is exaggerated by a seasonally strong pelagic/benthic coupling of ecosystems and variations in downslope food transfer. Due to the Arctic conditions and its far offshore location such a system will develop at low accumulation rates.

\section{CONCLUSIONS}

- The nearly year-round sea ice cover over the Vesterisbanken Seamount and its short-term retreat, mostly during August and September, results in episodic peak sediment and food supplies from surface waters. Ice edge blooms of phyto(diatoms) and zooplankton (beside others the planktic foraminiferNeogloboquadrina pachydermasin.) and melting sea ice deliver huge quantities of particulate and suspended organic matter and fine-grained terrigenous sediments into surface waters.

- Due to the downwelling TAYLOR current regime over the seamount, a rapid and effective transfer of food is supplied to the benthic ecosystems reflecting an intensive pelagic/ benthic coupling of ecosystems.

- Facies belts and biogenic structures reveal a clear depth zonation depending on variations in food supply as well as on different substrates due to variable slope inclinations and roughness of the volcanic foundation. Major facies belts are the crest facies down to $-260 \mathrm{~m}$, the shallow slope facies from around $-260 \mathrm{~m}$ to $-400 \mathrm{~m}$ and the deep slope facies below $400 \mathrm{~m}$.

- Small sponge-bryozoan-serpulid mounds and hedges as well as flatcake-like structures formed by the same organisms 
grow on a wide extended biogenic mat within the crest facies. On steeper margins extensive bryozoan thickets have developed on the volcanic foundation. The shallow slope facies is covered with semi-stabilized sandy mud bottoms and/or dark volcanoclastic sediments colonized by vast numbers of pectinidbivalves and onuphid polychates. Locally sponge-bryozoan-serpulid mounds are developed on elevations of the volcanic foundation. The deep slope facies comprises various kinds of sponge-bryozoan mounds, sponge mounds, and a typical sponge-crinoid assemblage on coarse volcanoclastics and lava surfaces.

- The dense organic meshwork formed by sponge spicules and bryozoan fragments on the upper sector of the seamount is unique in various ways. Most sponge spicules have a microbial cover, which is an ideal substrate for the settlement of larvae. The spiculite mat is predominantly formed by in situ decay of sponges revealing the actualistic formation of spiculites. The spiculite mat has various cryptic habitats, which are inhabited by bryozoans, ascidians, serpulids, and benthic foraminifers.

- Most of the sponges are $\mathrm{K}$ - strategists adapted to stable oligotrophic conditions. They survive in cold Arctic waters by forming residual bodies in winter. Bacterial symbiosis and/or take up of dissolved organic matter might support the nutrition of sponges.

- Prevalent nutrient sources depending on water depth, i.e. living phyto- and zooplankton versus particular organic matter, control species distribution and growth forms of bryozoans on the seamount.

- The lag deposit character and frequent iron/manganese stainings on particles suggest low accumulation rates for the mixed siliceous, carbonaceous and terrigenous uppermost sediment layers on the Vesterisbanken Seamount.

- Weak hydrothermal activities (yellowish to reddish brownish oxide crusts and stained soriaceous material) were observed as being widely distributed on the seamount edifice. These weak and still active hydrothermal emanations do not show any prominent influence on the biotic zonation. Pyroclastic eruptions took place variously during the Holocene, providing new semi-stabilized substrates for biogenic overgrowths at wide areas of the seamount.

- The different sponge-bryozoan-serpulid-echinoderm biogenic structures of the Arctic Vesterisbanken Seamount can be regarded as one potential end member of the Foramol facies with clearly defined controlling parameters, e.g. a strictly seasonal pelagic/benthic coupling of ecosystems and variations in downslope food transfer. Beside serving as a modern case study for similar composed fossil counterparts, carbonate production reveals a set of controlling parameters whose significance has been traditionally underestimated in the tropical counterparts.

\section{ACKNOWLEDGEMENTS}

We thank Captain Jonas and his crew for excellent support during the ARK V/1 expedition of RV PoLARSTERN in July 1990. Jayne Welling kindly improved the language. Christian Reimers and Beate Baader assisted in photgraphic repro-techniques. Very constructive reviews by Prof. Noel James and an anonymous reviewer are gratefully acknowledged.

\section{REFERENCES}

Altenbach, A. V., Unsöld, G. \& W Wlger, E. (1987): The hydrodynamic environment of Saccorhiza ramosa. - Ber. Sonderforschungsber. 313, 6, 47-68, Kiel

Armauer Hansen, G. (1885): Spongiadae. - The Norwegian NorthAtlantic Expeditions 1876-1878, 13 (Zoology), 25 pp., Christiania (Leipzig)

Augstein, E., Hempel, G., Schwarz, G., Thiede, J. \& Weigel, W. (1984): Die Expedition ARKTIS II des FS "Polarstern" 1984. - Ber. Polarforschung, 20, 192 pp., Bremerhaven

BERNHARD, F. R. (1979): Bivalve molluscs of the western Beaufort Sea. - Contr. Sci., 313, 80 pp, Los Angeles

BoEHLERT, G. W. (1987): A review of the effects of seamounts on biological processes. - In: Keating, B. H., Fr Yer, P., Batiza, R. \& Boehlert, G. W. (eds.): Seamounts, Islands and Atolls, Geophysical Monographs, 43, 319-333, Washington

BreItFuss, L. L. (1898): Die arctische Kalkschwammfauna. Arch.f.Naturgesch., 277-316, Berlin

BRÖNSTEDT, H. V. (1914): Porifera - Conspectus Faunae Groenlandicae. - Meddl. om Grønland, 23, 459-544, Kopenhagen

Bullivant, J. S. \& Dearborn, J. H. (1967): The fauna of the Ross Sea, Pt. 5. - New Zealand Dept. Scient. Industr. Res. Bull., 176, $76 \mathrm{pp}$, Wellington

BuRTON, M. (1934): Zoological results of the Norwegian scientific expeditions to East-Greenland. III. Report on the sponges of the Norwegian expeditons to East-Greenland $(1930,1931$, and 1932). - Skrifter om Svalbard og Ishavet, 61, 33 pp., Oslo

BurTon, M. (1959): Spongia. - The Zoology of Island, 2 (Part 3-4), 71 pp., Kopenhagen \& Reykjavik

Clark, A. H. (1970): Echinodermata Crinoidea. - Marine Invertebrates of Scandinavia, 3, 55pp., Oslo

EgGvin, J. (1963): Bathymetric chart of the Norwegian Sea and adjacent areas. Scale 1:5.000.000. - Fiskeridir. Havforskingsinst., Bergen

Eldholm, O. \& THIEDE, J.(1980): Cenozoic continental separation between Europe and Greenland. - Palaeogeogr., Palaeoclimatol., Palaeoecol., 30, 243-259, Amsterdam

FAIRBANKS, R. G. (1989): A 17.000 year glacio-eustatic sea level record: influence of glacial melting rates on the Younger Dryas event and deep ocean circulation. - Nature, 143, 637-642, London

FRISTEDT, K. (1885): Bidrag till Kännedomen om de vid Sveriges vestra kust lefvande Spongiae. - Kongl. Svenska VetenskapsAkad. Handl., 21/6, 56 pp., Stockholm

GrAF, G. (1989): Benthic-pelagic coupling in the deep-sea benthic community. - Nature, 341, 437-439, London

Gulliksen, B., Haug, T.\& SANDNES, K. (1980): Benthic macrofauna on new and old lava grounds at Jan Mayen. - Sarsia, 65, 137 148 , Bergen

HARMELIN, J.-G. (1975): Relation entre la forme zoariale et l'habitat chez les bryozoaires cyclostomes et consèquences taxonomique. - Docum. Lab. Geol. Fac. Sci. Lyon (hors Ser.) 3 (Bryozoa 1974), 369-384, Lyon

Hartmann, M., Lass, H. \& Puteanus, D. (1989): A new method for trace metal determination in seawater. - In: WeLZ, B. (ed.): 5. Colloquium Atomspektrometrische Spurenanalytik, 703-709

HaYwaRd, P. J. \& RYLAND, J. S. (1979): British Ascophoran bryozoans. - In: KeRMACK, D. M. \& BARNES, R.S. K. (eds.), Synopsis of the British Fauna (n. s.), 14, 1-312, Academic Press, London

Hempel, P., Schreiber, R., Johnson, L. \& ThIEde, J. (1991): The Vesterisbanken Seamount (Greenland Basin) - patterns of morphology and sediment distribution. - Marine Geology 96, 175-185, Amsterdam

HENTSCHEL, E. (1916): Die Spongien des Eisfjordes. -Zool. Ergebn. 
der Schwedischen Expedition nach Spitzbergen 1908, Teil II (3), 18 pp., Stockholm

HoGg, N. G. (1973): On the stratified TAYLOR column. - J. Fluid Mechanics, 58, 517-537, London

Hörmann, P. K. \& RaAse, P. (1991) Petrology of basalts from the Vesterisbanken (Greenland Sea). - Marine Geology (in press)

HUPPERT, H. E. (1975): Some remarks on the initiation of inertial TAYLOR columns. - J. Fluid Mechanics, 67, 397-412, London

JOHANNESSEN, O. M. (1986): Brief overview of the physical oceanography. - In: HuRdLE, B. G. (ed.): The Nordic Seas, 103-128, New York (Springer)

KLUGE, G. A. (1975): Bryozoa of the northern seas of the USSR. 711.pp., New Dehli (Amerind. Publishing Co.)

Koltun, V. M. (1959): Corneosiliceous sponges of the northern and far eastern seas of the USSR. - Keys for the identifications of the fauna of the USSR published by the Zoological Insitute of the Academy of Sciences of the USSR, (Akad. NAUK USSR) 67, 235 p., Moskow-Leningrad. (in Russian)

(1964): Sponges from the Antarctic. 1. Tetraxonida and Cornacuspongida. In: Biological results of the Soviet Antarctic Expedition 1955/1958, 2 Issled. Faunei Morei, 6-131, Moskow \& Leningrad

-- (1966): Four rayed sponges of the North and Far eastern Seas of the USSR (Order Tetraxonida). - Akad. NAUK USSR 90. 107 pp., Moskow \& Leningrad. (in Russian)

-- (1967): Glass sponges of the Northern and Far Eastern Seas of the USSR. - Akad. NAUK USSR 94, 124 pp., Moskow \& Leningrad (in Russian)

-- (1970): Sponges of the Arctic and the Antarctic: A faunistic review. - Sym. Zool. Soc. London, 25, 285-297, London

LAMBE, L.M. (1896): Sponges from the Atlantic Coast of Canada. -Trans. Roy. Soc. Can., Sec. 6, 183-211, Montreal

-- (1900): Catalogue of the recent marine sponges of Canada and Alaska. - Ottawa Naturalist, 14/9, 153-172, Ottawa

Le Bas, M. J., Le Martre, R. W., Streckeisen, A. \& Zanettin, B. (1986): A chemical classification of volcanic rocks based on the total alkali-silica diagram. - J. Petrol., 27, 745-750, Oxford

LeEs, A. \& BulleR, A. T. (1972): Modern temperate-water and warm-water shelf carbonate sediments contrasted. - Marine Geology, 13, M67-M73, Amsterdam

LuBINSKY, I. (1980): Marine bivalve molluscs of the Canadian central and eastern Arctic: Faunal composition and zoogeography. - Can. J. Fish. Aquat. Sci. Bull., 207, 1-111, Ottawa

LuNDBECK, W. (1902): Porifera. Homorrhaphidae and Heterorrhaphidae. - The Danish Ingolf-Expedition, 6/1, 105 pp., Hagerup (Kopenhagen)

-- (1905): Porifera. Desmacidonidae (pars.). - The Danish IngolfExpedition, 6/2, 219 pp., Hagerup (Kopenhagen)

-- (1909): The Porifera of East Greenland. - Meddr.om Grønland, 29, 423-464, Kopenhagen

-- (1910): Desmacidonidae (pars.). - The Danish Ingolf-Expedition, 6/3, 124 pp., Hagerup (Kopenhagen)

LutZE, G. F. \& AltenBACH, A. V. (1987): Rupertina stabilis (W ALlich), eine hochangepaßte, filtrierende BenthosForaminifere. - Ber. Sonderforschungsber. 313, 6, 31-46, Kiel

MARENZELler, E. (1886): Poriferen, Anthozoen, Ctenophoren und Würmer von Jan Mayen. - Die Österreichische Polarstation Jan Mayen, Beobacht. Ergeb., 3, 9-14, Wien

Merejkowsky, C. (1878): Les Éponges de la Mer Blanche. - Mem. Acad. Imper. Scienc. St. Petersbourg. - 26/7, 7.Ser., 51 pp., St.Petersbourg

Nelson, C.S., Hydon, F.M., Keane, S. L., Leask, W. L. \& Gordon, D. P. (1988): Application of bryozoan zoarial growth-form studies in facies analysis of non-tropical carbonate deposits in New Zealand. - Sed. Geology, 60, 301-322, Amsterdam

NoRDgAaRD, O. (1918): Bryozoa from the Arctic Regions. - Troms $\varnothing$ Museum Årshefter, 40/1, 1-99, Troms $\varnothing$

OCKELMANN, W.K. (1958): The zoology of east Greenland - marine Lamellibranchiata. - Meddr. om Grønland, 107/7, 1- 256, Kopenhagen
OschmanN, W. (1990): Dropstones - rocky mini-islands in highlatitude pelagic soft substrate environments. - Senckenbergiana marit., 21/1-4, 55-75, Frankfurt

-- (1991): Ecology and bathymetry of the Late Quaternary shelly macrobenthos from bathyal and abyssal areas of the Norwegian Sea. - Senckenbergiana marit., 21/5-6, Frankfurt

PIEPENBURG, D. (1988): Zur Zusammensetzung der Bodenfauna in der westlichen Fram Straße. - Ber. Polarforschung, 52, 1-117, Bremerhaven

Powell, N.A. (1968): Bryozoa (Polyzoa) of Arctic Canada. - J. Fish. Res. Bd. Canada, 25/11, 2269-2320, Toronto

RASMUSSEN, B. N. (1965): On taxonomy and biology of the north Atlantic species of the asteroid genus Henricia Gray. - Medd. Danm. Fiskeri. Havunders. N.S., 4/7, 157-213, Kopenhagen

RYLAND, J. S. (1963): Systematics and biological studies on Polyzoa (Bryozoa) from western Norway. - Sarsia, 14, 1-59, Bergen

Schмiтt, M., Botz, R. \& FABER, E. (1991): Ultrasonic vacuun degassing of water for methane extraction. - Analytical Chemistry (in press)

Schopf, T. J. M. (1969): Paleoecology of ectoprocts (bryozoans). - J. Paleont. 43, 234-244, Tulsa

SchulzE, F.E. (1900): Die Hexactinelliden. - Fauna Arctica, 1 (Lfg.1), 86-108, Fischer, Jena

-- (1903): Caulophacus arcticus (ARMAUER HANSEN) und Calycosoma gracilem F.E.ScH. nov.spec. - Abh. K. preuss. Akad. Wiss., 1903, 1-22, Berlin

STACH, L. W. (1936): Correlation of zoarial growth form with habitat. - J. Geol. 44, 60-66, Chicago

SteENSTRUP, E.\& Tendal, O.S.(1982): The genus Thenea (Porifera, Demospongia, Choristida) in the Norwegian Sea and adjacent waters; an annotated key. - Sarsia: 67, 259-268, Bergen

SwIFT, J. H. (1986): The Arctic waters. - In: HuRdLE, B. G. (ed.), The Nordic Seas, 129-154, Springer Verlag, New York

TAYLOR, G. I. (1923): Experiments on the motion of solid bodies in rotation fluids. - Proc. Roy. Soc. London, B., Biol. Sci., 104A, 213-218, London

TAYLOR, P. D. (1979): The inference extrazooidal feeding currents in fossil bryozoan colonies. - Lethaia, 12, 47-56, Oslo

Tendal, O. S. (1970): Sponges from Jörgen Brönlund Fjord, North Greenland. - Meddr. om Grönland, 184/7, 1-14, Kopenhagen (1979): Sponges of Jan Mayen. - Astarte, 12, 53-55, Troms $\varnothing$

ThIEDE, J. \& HeMPEL, G. (1991): Die Expedition ARKTIS-VII/1 mit FS "PolarsteRN" 1990. - Ber. Polarforschung, 80, 1-137, Bremerhaven

ThORSON, G. (1958): The Godthaab expedition 1928: Scaphopoda, Placophora, Solenogastres, Gastropoda, Prosobranchia, Lamellibranchiata. - Medd. Grønland, 81/2, 117pp, Kopenhagen

van W AGoner, N. A., Mudie, P. J, Cole, F. E. \& Daborn, G. (1989): Siliceous sponge communities, biological zonation, and Recent sea-level change on the Arctic margin: Ice Island results.. Can. J. Earth Sci., 26, 2341-2355, Montreal

VINJE, T. (1985): The physical environment of the western Barents Sea: Drift, composition, morphology and distribution of the sea ice fields in the Barents Sea. -Norsk. Polarinst. Skr., 179C, 126, Oslo

Vosmaer, G. C. J. (1885): The Sponges of the "Willem Barents" Expedition 1880 and 1881. - Bijdr. Dierk., 12, 1-47, Amsterdam

Wallrabe-Adams, H. J. (1991): Submarine Aschelagen bei Vesterisbank (Grönlandsee). - IN: THIEDE, J. \& HEMPEL, G. (Hrsg.), Die Expedition ARKTIS-VII/1 mit FS "PolarSTERN" 1990, Ber. Polarforschung, 80, 82- 86, Bremerhaven

Winston, J. E. (1981): Feeding Behavior of Modern Bryozoans. IN: BROADHEAD, T. W. (ed.): Lophophorates, Notes for a short course. pp. 21, University of Tennessee, Cincinnati (1978): Polypide morphology and feeding behavior in marine ectoprocts. - Bull. Mar. Sci. 28, 1-31, Miami

Manuscript received January 9, 1992

Revised manuscript accepted July 14, 1992 